\title{
Updated stratigraphic framework and biota of the Ediacaran and Terreneuvian in the Alcudia-Toledo Mountains of the Central Iberian Zone, Spain
}

\author{
Revisión actualizada de la estratigrafía y biota del Ediacárico \\ y Terranóvico de los Montes de Alcudia-Toledo, Zona \\ Centroibérica, España
}

\author{
J.J. Álvaro ${ }^{1}$, I. Cortijo 2 , S. Jensen ${ }^{3}$, S. Lorenzo ${ }^{4}$, T. Palacios ${ }^{3}$ \& A.P. Pieren ${ }^{5}$ \\ ${ }^{1}$ Instituto de Geociencias (CSIC-UCM), Dr. Severo Ochoa 7, 28040 Madrid, Spain. Email: jj.alvaro@csic.es, ORCID ID: https:// \\ orcid.org/0000-0001-6294-1998 \\ ${ }^{2}$ Villuercas-Ibores-Jara UNESCO Global Geopark, Pintores 10, 10003 Cáceres, Spain. Email: icortijo@dip-caceres.es, ORCID \\ ID: https://orcid.org/0000-0002-6027-9002 \\ ${ }^{3}$ Área de Paleontología, Facultad de Ciencias, Universidad de Extremadura, 06071 Badajoz, Spain. Email: soren@unex.es \\ medrano@unex.es; ORCID ID: https://orcid.org/0000-0003-4573-9282, https://orcid.org/0000-0002-4917-0559 \\ ${ }^{4}$ Departamento de Ingeniería Geológica y Minera - IGeA, Universidad de Castilla-La Mancha, Manuel Meca 1, 13400 Almadén, \\ Spain. Email: saturnino.lorenzo@uclm.es; ORCID ID: https://orcid.org/0000-0001-7442-4760 \\ ${ }^{5}$ Departamento de Geodinámica, Estratigrafía y Paleontología, Facultad de Ciencias Geológicas, Universidad Complutense, \\ José Antonio Nováis 12, 28040 Madrid, Spain. Email: apieren@ucm.es; ORCID ID: https://orcid.org/0000-0001-8783-2368
}

\begin{abstract}
An updated stratigraphic subdivision of the Ediacaran and Terreneuvian in the Alcudia valley and the Toledo Mountains, Central Iberian Zone, is documented here. The Lower Alcudian-Domo Extremeño Supergroup is subdivided, from bottom to top, into the conformable Guadiana (La Coronada and Sta. Ma de Zújar formations) and Campanario (Botija, Monroy and Orellana formations) groups. The supergroup contains biostratigraphically non-significant bacterial acritarchs and dubious fossils, but its Ediacaran age is constrained by detrital zircon analyses. This siliciclastic sedimentary package is unconformably overlain by either the siliciclastic-carbonate Ibor Group (Castañar, Villarta and Arrocampo formations) or the siliciclastic Cíjara Formation. The fossil content of the former group includes Sabelliditids, Vendotaenids, macrophytes, bioaccumulations and reefs rich in Cloudina, Sinotubulites, Protolagena and stromatolites and thrombolites, and a wide diversity of ichnofossils; whereas the Cíjara Formation has yielded bacteria attributed to Bavlinella and Palaeogomphosphaeria, and simple trace fossils (Gordia, Helminthoidichnites and treptichnids). The Ediacaran-Cambrian boundary, based on ichnofossils, lies at the base of the Arrocampo Formation and the uppermost part of the Cíjara Formation. In the Alcudia valley, the Ibor Group is subdivided into another three-fold, lithologically equivalent subdivision, known as the Tamujar, Hinojosas (rich in ichnofossils, such as treptichnids, Monomorphichnus, Psammichnites and Taphrelminthopsis) and Cabezarrubias (including Bergaueria and Planolites) formations. Another unconformity, intra-Fortunian in age, marks the tops of the Ibor Group and the Cíjara Formation, wich are subsequently overlain by the San Lorenzo Formation and some megabreccia beds, respectively. Overlying the slope-related Fuentes,
\end{abstract}

Recibido el 4 de junio de 2019; Aceptado el 21 de agosto de 2019; Publicado online el 12 de noviembre de 2019

Citation / Cómo citar este artículo: Álvaro J.J. et al. (2019). Updated stratigraphic framework and biota of the Ediacaran and Terreneuvian in the Alcudia-Toledo Mountains, Central Iberian Zone, Spain. Estudios Geológicos 75(2): e093. https://doi.org/10.3989/ egeol.43620.548.

Copyright: () 2019 CSIC. This is an open-access article distributed under the terms of the Creative Commons Attribution-Non Commercial (by-nc) Spain 4.0 License. 
Membrillar and Navalpino megrabreccia beds, the Terreneuvian-Cambrian Series 2, heterolithic Pusa Formation is subdivided into thre members, the middle one characterized by the record of phosphate ore deposits (e.g., the Fontanarejo Bed). The formation is shale dominated and has yielded the body-fossil Beltanelliformis and numerous ichnofossils (Monomorphicnus and Treptichnus; lower member), sponge spicules associated with thrombolites (middle member), and Scenella, trilobites, archaeocyaths and ichnofossils (Dactyloidites, Psammichnites, Rusophycus and Teichichnus; upper member). Where the megabreccia beds are absent, the Ibor Group is unconformably overlain by the San Lorenzo and Fuentepizarra formations, the latter containing phosphatic limestone interbeds rich in skeletonized microfossils, such as Anabarella, which represents the Fortunian-Cambrian Stage 2 boundary interval.

Keywords: Stratigraphy, Acritarchs; Shelly fossils; Ichnofossils; West Gondwana.

\section{RESUMEN}

Se presenta en este trabajo una revisión actualizada de la estratigrafía del Ediacárico-Terranóvico del valle de Alcudia y los montes de Toledo, Zona Centroibérica. Se subdivide el Supergrupo infrayacente ediacárico del Alcudiense Inferior-Domo Extremeño en los Grupos del Guadiana (Formaciones de La Coronada y Sta. M ${ }^{a}$ de Zújar) y de Campanario (Formaciones de Botija, Monroy y Orellana). El supergrupo contiene varios acritarcos sin utilidad bioestratigráfica, así como dubiofósiles, pero su edad se ha establecido claramente a partir de zircones detríticos. Este litosoma siliciclástico aparece recubierto mediante contacto disconforme con el Grupo mixto de Ibor (Formaciones de Castañar, Villarta y Arrocampo) o la Formación siliciclástica del Cíjara. El contenido fósil del Grupo de Ibor incluye sabellidítidos, vendoténidos, macrofitas, bioacumulaciones y arrecifes con Cloudina, Sinotubulites, Protolagena y estromatolitos y trombolitos, así como una amplia variedad de icnofósiles; la Formación del Cíjara ha librado microfósiles bacterianos como Bavlinella y Palaeogomphosphaeria, y pistas fósiles simples (Gordia, Helminthoidichnites y treptícnidos). El límite Ediacárico-Cámbrico, a partir de icnofósiles, se sitúa en la parte basal de la Formación de Arrocampo y en la parte terminal de la del Cíjara. El valle del Alcudia ofrece algunas peculiaridades, lo que se refleja por el mantenimiento de una subdivisión litoestratigráfica propia: el Grupo de Ibor se divide en las Formaciones de Tamujar, Hinojosas (caracterizada por su contenido en icnofósiles, que incluye treptícnidos, Monomorphichnus, Psammichnites y Taphrelminthopsis) y Cabezarrubias (con Bergaueria y Planolites). Otra discontinuidad mayor se reconoce a techo del Grupo de Ibor y de la Formación del Cíjara, recubiertos respectivamente por la Formación de San Lorenzo y unas capas de megabrechas muy características. Las megabrechas, interpretadas como depósitos de talud y conocidas como las capas de Fuentes, Membrillar y Navalpino, se sitúan a base de la Formación del Pusa, de composición heterolítica y de edad Terranóvico a Serie cámbrica 2. Se subdivide el Pusa en tres miembros, destacando el intermedio por el registro de yacimientos de interés económico de fosfato (Capa de Fontanarejo). La Formación del Pusa contiene el fósil de cuerpo blando Beltanelliformis así como numerosos icnofósiles (Monomorphicnus y Treptichnus; miembro inferior), espículas de esponja asociadas con trombolitos (miembro intermedio) y Scenella, trilobites, arqueociatos e icnofósiles (Dactyloidites, Psammichnites, Rusophycus y Teichichnus; miembro superior). En ausencia de megabrechas, el Grupo de Ibor aparece directamente recubierto por las Formaciones de San Lorenzo y Fuentepizarra, esta última caracterizada por su contenido en calizas fosfáticas ricas en microfósiles, como Anabarella, que caracterizan la transición Fortuniense-Piso Cámbrico 2.

Palabras clave: Estratigrafía; Acritarcos; Microfósiles, Icnofósiles; Gondwana Occidental.

\section{Introduction}

The Iberian Massif of the western Iberian Peninsula was subdivided by Lotze (1945) into several Variscan tectonostratigraphic domains or "zones", which are currently used in pre-Variscan and Variscan palaeogeographic and geodynamic reconstructions (Fig. 1A). The Central Iberian Zone was formally defined by Julivert et al. (1972) by grouping together Lotze's Galician-Castilian and East Lusitanian-Alcudian Zones. Both sub-domains differ in the relative abundance of Variscan syn-orogenic granitoid bodies associated with high-grade metamorphic rocks (more abundant in the former), but the contact between the two sub-domains is not sharp but gradational. In the NW segment of the Central Iberian Zone, several allochthonous complexes (Galicia-Trás-os-Montes Zone; Farias et al., 1987) are superposed, which will not be considered below, such as the Cabo Ortegal and Ordenes complexes and the Malpica-Tuy Band in Galicia (Spain), and the Bragança and Morais complexes in Trás-osMontes (Portugal; Ribeiro et al., 1990) (Fig. 1A).

One of the stratigraphic peculiarities of the Central Iberian Zone is the presence of a Furongian gap, in some cases scouring deeper and eroding the entire Cambrian and part of the uppermost Ediacaran. As a result, the widespread 'Purple Series' and Armorican Quartzite (Lower Ordovician) occur unconformably overlying an inherited palaeorelief composed of Ediacaran-'lower Cambrian' strata. The Furongian uplift and subsequent denudation is related to the so-called Toledanian 


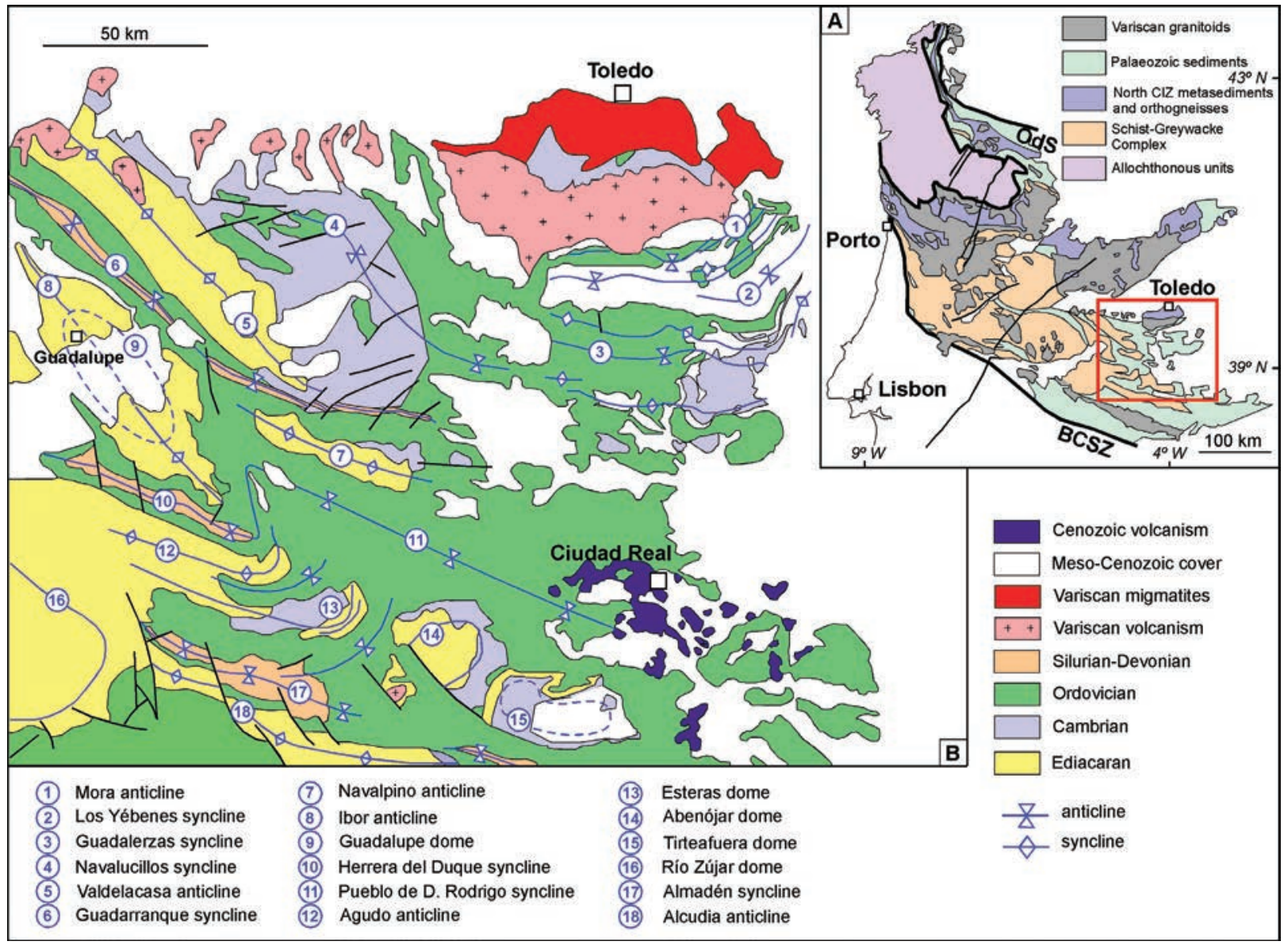

Fig. 1-A. Geological map of the Central Iberian Zone, Iberian Massif. B. Geological sketch showing the main Variscan tectonostratigraphic units reported in the text from the Alcudia-Toledo Mountains, Central Iberian Zone; acronyms: BCSZ Badajoz-Córdoba Shear Zone, OdS- Ollo de Sapo anticline; modified from Julivert et al. (1972).

Phase, which affected the Central Iberian and OssaMorena Zones of the Iberian Massif and the Anti-Atlas of Morocco (Álvaro \& Vizcaïno, 2018; Sánchez García et al., 2019) and is associated with the onset of: (i) a variable stratigraphic hiatus represented by angular discordance and paraconformable discontinuities overlain by Furongian breccias and conglomerates, punctuated, in the Ossa-Morena Zone, by the Venta del Ciervo tuff ( 489 Ma; López-Guijarro et al., 2008); and (ii) the intrusion and extrusion of large Furongian granitoiddominant and volcanic/volcaniclastic bodies with calcalkaline affinity, such as the Ollo de Sapo and Urra formations. Although some authors have interpreted these igneous rocks as related to both subduction (e.g., Castro et al., 2002; Díez Montes et al., 2010; Montero et al., 2017; García-Arias et al., 2018) and an intermediate magmatism associated with migmatites that extended subduction processes until at least ca. $465 \mathrm{Ma}$ (Pereira et al., 2018), the Toledanian Phase has been recently reinterpreted as a break-up unconformity (for a summary, see Sánchez-García et al., 2019) representing the sharp transition from rift to drift conditions that led to the subsequent opening of the Rheic Ocean (Linnemann et al., 2007; von Raumer \& Stampfli, 2008; Nance et al., 2010, 2012).

The aim of this paper is to offer an updated synthesis of the Ediacaran-Terreneuvian stratigraphy in the Alcudia valley and the Toledo Mountains, southwestern Central Iberian Zone (Fig. 1B), emphasizing recent palaeontological data from organic-walled and shelly microfossils and ichnofossils. This synthesis is made to provide a basis for discussions during the international meeting focused on the "Ediacaran and the Ediacaran-Cambrian transition" (IMECT) organized under the support of the 
Villuercas-Ibores-Jara UNESCO Global Geopark, the Spanish Geological Society (SGE), the Spanish Geological Survey (IGME), and the International Subcommisions on Ediacaran and Cambrian Stratigraphy, which will take place in Guadalupe (Extremadura) in October 2019.

\section{Geodynamic overview on the Cadomian Orogeny}

In the Iberian Peninsula, the collision between a Cadomian arc/back-arc system (Ossa-Morena Zone) and the peri-Gondwana margin (Central-Iberian, WestAsturian Leonese and Cantabrian Zones) resulted in the formation of an orogenic belt. Arc growth started at least ca. $630 \mathrm{Ma}$, as evidenced by igneous zircon entrained by Cadomian and Cambrian rift-related rocks (SánchezGarcía et al., 2016, 2019). The Cadomian suture was somewhat reactivated during the Variscan Orogeny, and its remains are tentatively situated along the BadajozCórdoba (blastomylonitic) Shear Zone (BCSZ; Fig. 1A), close to the Pedroches Batholith, which also marks the contact of the Ossa-Morena and Central Iberian Zones. The fore-arc region should be located southwest of the Ossa-Morena Zone, which represents the remaining of such arc left on the Gondwanan margin after opening of the Rheic Ocean in Early Ordovician times. By ca. 600 $\mathrm{Ma}$, a back-arc basin formed, as documented by ophiolite successions (Calzadilla serpentinite and related rocks; Arenas et al., 2018), the infilling of which is represented by the Serie Negra (Ossa-Morena Zone) and the "Lower Alcudian" and "Domo Extremeño" groups (Central Iberian Zone). The only exposed remain of the Cadomian Arc is preserved at the basement of the Obejo-Valsequillo Domain, a thrusting system complex of the Ossa-Morena Zone, bounded to the South by the BCSZ (e.g., the Portalegre, Hornachos and Higuera de Llerena faults). The Obejo-Valsequillo Domain includes an upper Ediacaranlowermost Terreneuvian volcanosedimentary succession (Serie Negra Group and Malcocinado Formation) associated with arc-related plutons, which are unconformably overlain by a Palaeozoic succession characteristic of the Central Iberian Zone; Martínez Poyatos, 2002; San José et al., 2004). The northern limit of this domain, affected in surface by the intrusion of the Pedroches Batholith, would represent a relic of the Cadomian suture, whereas the remaining part of the Cadomian Arc drifted from Gondwana, as part of Avalonia since Early Ordovician times (Quesada, 1990) (Fig. 2). The Cadomian suture was seemingly reactivated as an uplifted rifting shoulder during Cambrian times, and as a Variscan sinistral shearing affecting the Ossa-Morena/Central Iberian contact (Quesada, 1990; Ábalos et al., 1991; Fig. 2).

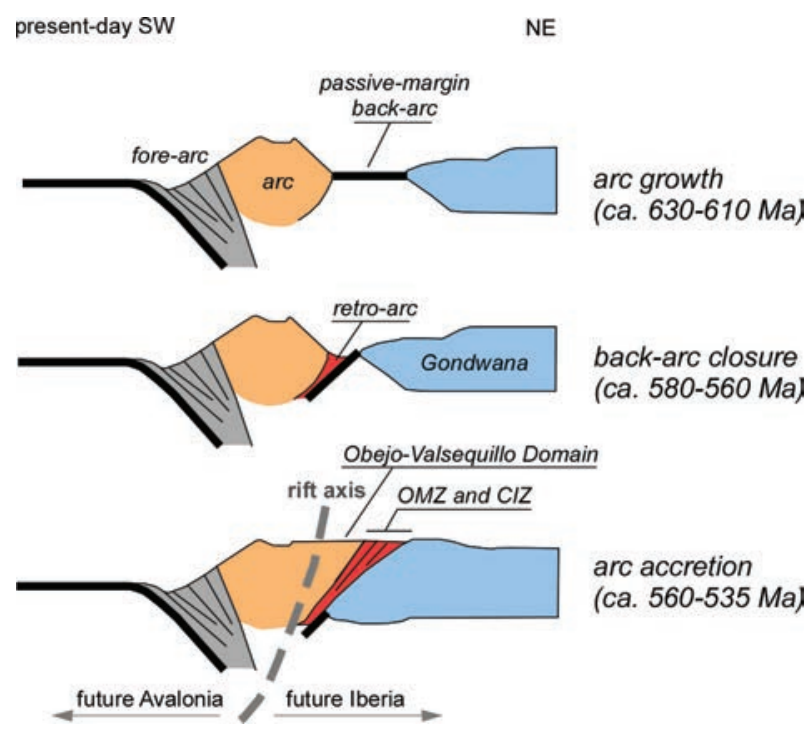

Fig. 2-Geodynamic sketch illustrating the evolution of the Cadomian orogeny in the Iberian margin of Gondwana; modified from Sánchez-García et al. (2016); OMZ- Ossa-Morena Zone, ClZ- Central Iberian Zone.

During the onset of the Cadomian orogeny, the cratonward side of the back-arc basin displayed a northeastward increasing depth and availability of accommodation space (Quesada, 1991; Eguíluz et al., 1995, 2000), then becoming a retro-arc foreland basin (Quesada, 2019a, b). Denudation of the arc can be geochronologically controlled by the input of exotic clasts (such as black chert lydites) and detrital zircon derived from the neighbouring uplifting arc (Pereira et al., 2012a, b; Sánchez-García et al., 2019). By ca. $580 \mathrm{Ma}$, the back-arc basin started to close, antithetic to the main subduction system (i.e. with the Ossa-Morena Zone as upper plate), as indicated by significant emplacement of the calc-alkaline arc-related rocks of the Malcocinado Group and related plutons in the central and (mainly) northern parts of the Ossa-Morena Zone. This gave rise to a secondary arc in this region, erupted onto/intruded into deformed, pre-orogenic to synorogenic rocks of the Serie Negra, and which extended until ca. $535 \mathrm{Ma}$ (Quesada, 2019a, b).

Closure of the back-arc basin led to progressive collision of the arc with the margin of Gondwana in the range of 570-535 Ma. An oblique regime is suggested by both the large diachroneity of the collision process and the different nature of the basement across the suture (Quesada, 2019a, b). After the erosion of the Cadomian Arc, palaeocurrents changed from the present-day SW (the setting of the arc) to the NE, and the detrital zircon and clasts changed of source, from the SW Cadomian arc to the NE Cantabro-Ebroan Source Land (Vilas \& de San José, 1990; 
Quesada, 1991, 1996; San José et al., 1992; Rodríguez Alonso et al., 1995, 2004; Eguíluz et al., 2000; Valladares et al., 2000, 2002).

The suture zone, bringing the Ossa-Morena Zone onto the Central Iberian Zone, as indicated by shedding of Ossa-Morena lithologies as clasts into syn-orogenic deposits in the Central-Iberian part of the back-arc basin (Pieren Pidal, 2000), was reactivated several times (during Cambrian rifting and during the subsequent Variscan orogeny), being presently exposed within the broad Badajoz-Córdoba shear Zone and probably beneath the Obejo-Valsequillo Domain (Quesada \& Dallmeyer, 1994).

In the Ossa-Morena part of the retro-arc basin, the relatively abrupt change from Cadomian subduction (latest evidence at ca. $533 \mathrm{Ma}$ ), with evidence of two pulses of Cadomian deformation and coeval high-grade syntectonic metamorphism related to accretion in an orogenic wedge complex, to Cambrian rifting (earliest at ca. 530 Ma; Bandrés et al., 2002, 2004; Sánchez-García et al., 2019 ) is correlative with the three-fold geodynamic evolution recorded in the Central Iberian Zone, only loosely constrained in time due to the scarcity of radiometric data, from (i) back-arc (passive-margin) to (ii) back-arc (retroarc) foreland, and (iii) rift conditions. Three geodynamic models are at present proposed to explain this EdiacaranTerreneuvian arc-to-rift turnover in the Iberian margin of West Gondwana, which are not necessary exclusive, involving: (i) the oblique collision of a mid-ocean ridge with the trench located at the outer Gondwana active margin, which would have progressively transformed the former subduction margin into a transcurrent one; (ii) a variant of the previous model, adding a component of subduction of the mid-ocean ridge beneath the continental upper plate; and (iii) a process of slab-pull related to the onset of subduction in the Iapetus and Prototethys oceans that may have triggered slab roll-back and back-arc rifting along the previous active margin around northern Gondwana (for a summary, see Sánchez-García et al., 2019).

In the Cadomian retro-arc basin preserved in the Central Iberian Zone, two major geodynamic episodes are recognized: (i) a late Cadomian folding event, unrelated to both schistosity and metamorphism (e.g., Apalategui et al., 2009), and stratigraphically identified as the distinct gap that separates the traditional "Lower Alcudian" (ca. 580-560 Ma) and "Upper Alcudian" (ca. 550-540 Ma on the basis of detrital zircon; Talavera et al., 2015) packages that exhibit two different styles of deformation; and (ii) the late metamorphic Sardoal event that attained medium pressure/high temperature conditions at ca. $530 \mathrm{Ma}$ in the vicinity of the Badajoz-Córdoba Shear Zone (Henriques et al., 2015, 2017). The latter event broadly correlates with the intra-Terreneuvian breakdown of the former retro-arc basin and the beginning of extensional conditions broadly marked by the base of the Pusa Formation.

\section{Structural style of the Central Iberian Zone}

The southwestern boundary of the Central Iberian Zone is broadly located along the Badajoz-Córdoba Shear Zone and its northeastern boundary along the Ollo de Sapo Anticline (Díez Balda et al., 1990) (Fig. 1A). The former represents the reactivated remains of an ophiolitebearing Cadomian suture (N-MORB amphibolites and dismembered serpentinite slices; Ábalos, 1990; Quesada \& Dallmeyer, 1994; Arenas et al., 2018; Díez Fernández et al., 2019), and the latter a major normal Cambrian fault that episodically separated platform and basinal settings (another example is the Vivero Fault separating the Ollo de Sapo Anticline and the Lugo Dome), and played a key role during the Variscan Orogeny as major reactivated thrust systems (Martínez Catalán et al., 1992; Russo \& Bechstädt, 1994; Álvaro et al., 2010).

Three main pre-Mesozoic deformation events are superposed in the Central Iberian Zone: (i) a Cadomian folding phase, (ii) the Toledanian Phase, and (iii) the Variscan deformation.

(i) The Pre-Ordovician Schist-Greywacke Complex of Portugal (Carrington da Costa, 1950; Teixeira, 1955) and Spain (García de Figuerola, 1971; Rodríguez Alonso, 1979; Díez Balda, 1986) displays two constraining styles of deformation separated by an angular discordance that marks the traditional "Lower Alcudian"/“Upper Alcudian" contact. Originally, the discordance was described in the Esteras River Anticline by Bouyx (1970) and in the Alcudia Anticline by Redlin (1955) and Crespo \& Rey (1972). The intra-Ediacaran deformation event produced folding with vertical axes with development of neither schistosity nor volcanic influence (Llopis et al., 1970; Parga \& Vegas, 1971, 1975; Ortega \& González Lodeiro, 1986), representing a volcanically poor "late Cadomian folding event" related to oblique collision of the arc and oblique closure of the back-arc basin. The age of this deformation event is bracketed by detrital zircon dates, ranging from ca. 580-560 Ma for the "Lower Alcudian" to ca. 550-540 Ma for the "Upper Alcudian" sandstones (Talavera et al., 2015).

(ii) The Furongian Toledanian Phase has been commonly mistaken with the Mid-Late Ordovician Sardic Phase (e.g., Moreno et al., 1976; Díez Balda et al., 1990) reported in Sardinia, the Occitan Domain and the Eastern Pyrenees (Álvaro et al., 2016a; Pereira et al., 2018). The Toledanian Phase, geodynamically interpreted as a 
result of a break-up unconformity (Sánchez-García et al., 2019), is marked by an angular discordance in the southern Central Iberian Zone, which separates variably tilted Ediacaran-to-Cambrian Series 2 packages from an overlying Ordovician succession. The involved gap includes, at least, most of the Furongian and basal Ordovician, although the erosion can incise into the entire Cambrian and part of the Ediacaran basement (Gutiérrez-Marco et al., 2002). In contrast, in the northeastern (palaeogeographically proximal to Gondwana) Iberian Massif's units, such as the northeastern Central-Iberian, West Asturian-Leonese and Cantabrian zones and their lateral prolongation into the Iberian Chains, the rift/drift turnover is transitional and conformable, despite some local gaps in the Cantabrian Zone (Aramburu et al., 2004). The 'Purple Series' and the Armorican Quartzite contain an ubiquitous conglomeratic and quartzitic succession that broadly seals the Toledanian palaeorelief and represents the return to stable platform conditions (McDougall et al., 1987; Gutiérrez-Alonso et al., 2007; Shaw et al., 2012, 2014). In the Ossa-Morena Zone, the break-up unconformity is locally capped by slope-related to alluvial breccias and conglomerates, dated at ca. $489 \mathrm{Ma}$ (Venta del Ciervo K-bentonite; López Guijarro et al., 2008), which rapidly evolved into open-shelf marine conditions that prevailed until Early Devonian times.

Associated with the Toledanian Phase, a FurongianEarly Ordovician felsic-dominant magmatic episode is recognized in the Central Iberian Zone, geographically bracketed between the Urra Formation marking its southwestern boundary and the Ollo de Sapo Formation along its northern boundary, as well as the (para) autochthonous realms of the NW Iberian Variscan Massif. Both volcanosedimentary belts represent a significant igneous event, spanned between the late Furongian and the Floian (ca. 495-470 Ma). These igneous rocks are dominantly felsic and calc-alkaline exhibiting an arc-like geochemical signature that some authors have interpreted as a result of subduction (Castro et al., 2002; Fernández et al., 2008; Del Greco et al., 2016, and references therein), whereas others argue that they were generated by melting of a subduction-related Neoproterozoic crust being its geochemical signature inherited (Díez Montes et al., 2010; García-Arias et al., 2018; Sánchez-García et al., 2019). The interplay of zircon source provenances and retrodeformation of the Ibero-Armorican Arc and Alpine superposition is providing conditions amenable to everlasting discussions on palaeogeographic interpretations (for a review, see Murphy et al., 2016). The putative association of the Toledanian unconformity and the emplacement of calc-alkaline volcanics are interpreted, in the Marão Anticline and the Amêndoa-Carvoeiro Synform of the Central Iberian Zone, as the record of compressive/transpressive tectonics (Romão et al., 2005). These authors have described cleavage-bearing folds with steep axial planes at high angles to Variscan structures, which have been interpreted as transient compression and dextral strike-slip features along the Central Iberian/OssaMorena zone boundary. Despite the diachronism of the Furongian Toledanian event and the Sardic intra-Ordovician phase, Romão \& Ribeiro (1993), Romão et al. (2005, 2013) and Amaral et al. (2014) have interpreted the Toledanian and Sardic events as the migration, in time, of a single geodynamic regime. However, according to Hammann et al. (1982), Ribeiro et al. (1990), Quesada (1990) and Gutiérrez-Marco et al. (2002), among others, the Toledanian and Sardic Phases are separated in time. Despite the exception yielded by the Marão Anticline and the Amêndoa-Carvoeiro Synform, the Toledanian and Sardic phases are related to neither metamorphic nor cleavage features, two features characteristic of the Variscan deformation.

(iii) The Variscan deformation was responsible for the origin of two different tectonic domains in the Central Iberian Zone, the Domain of Recumbent Folds to the NE and the Domain of Vertical Folds to the SW (Díez Balda et al., 1990), roughly coinciding with the so-called Ollo de Sapo and Schist-Greywacke domains, respectively (Martínez Catalán et al., 2004). The latter, on which this paper is focused, is characterized by geographical landscapes exhibiting an Appalachian geomorphological style composed of narrow synclines topped by the 'Purple Series' and the Armorican Quartzite, and broad antiforms exhibiting Ediacaran-Cambrian successions in their cores. The overall Variscan structure of the Central Iberian Zone is the overprinting result of three distinct deformation events plus a somewhat later activity related to the subvertical shear zones or to faults (Díez Balda et al., 1990; Díez Fernández \& Pereira, 2016; Dias da Silva et al., 2017).

Among the numerous anticlines of the Central Iberian Zone, for practical reasons, five Variscan tectonostratigraphic units with distinct lithological features will be described below: the Extremenian Anticlinorium, the Abenójar-Tirteafura Dome and the Alcudia, Valdelacasa and Ibor-Navalpino anticlines.

\section{Historical background on stratigraphic terminology}

The Ediacaran System of the southwestern Central Iberian Zone is composed of a thick and relatively monotonous succession of deep-water siliciclastic rocks (Pieren Pidal, 2000), which change laterally into the heterolithic sandstone/shale alternations of the Beiras Group (Medina 
et al., 1998; Pereira et al., 2012b; Meireles et al., 2013). The monotonous lithologies of the Spanish side, combined with relatively scattered outcrop and later tectonic overprint, has complicated the elucidation in detail of the stratigraphic successions. Symptomatic of these problems, the relative order of lithostratigraphic units has been an endless subject of discussion (e.g., Pardo Alonso \& Santamaría Casanovas, 1992). A greater lithological diversity is developed in shallower-water sedimentary rocks crossing the Ediacaran-Cambrian transition, but, even there, many uncertainties remain in the stratigraphic correlation throughout the Central Iberian Zone. As a result, a plethora of lithostratigraphic terms is available in the Spanish regional bibliography, differing between regions but also with competing schemes being developed within the same region. Much of this nomenclature was developed without formal definitions and published in $\mathrm{PhD}$ theses and extended abstracts. Below we provide both a brief historical background and an attempt at unifying a common lithostratigraphic terminology.

The Schist-Greywacke Complex of Carrington da Costa (1950) and Teixeira $(1954,1955)$ represents the lithosome of the Central Iberian Zone that underlies the Toledanian gap, and includes an Ediacaran-Cambrian Series 2 heterolithic (though siliciclastic-dominated) succession (Capote et al., 1977; Vegas et al., 1977; Bernardo de Sousa, 1984; Rodríguez Alonso, 1984, 1985; Vilas et al., 1987; Medina, 1996). Its subdivision and the presence/absence of major stratigraphic discontinuities have been an everlasting matter of discussion.

Lotze $(1956)$ and Bouyx $(1961,1962)$ were the pioneers to focus their attention on the Alcudia Anticline. They coined the "Valcasa Series" and the "Alcudia Shales", respectively, to refer to the exposures unconformably overlain by the Armorican Quartzite and associated strata. Although one of Lotze's students (Redlin, 1955) was the first to report the presence of a major stratigraphic discontinuity, his finding was only highlighted by Bouyx (1961, 1962), Ovtracht \& Tamain (1970) and Crespo \& Rey (1972), who subdivided Bouyx's unit into the "Lower Alcudian" and "Upper Alcudian", two terms of the 1970s referring to both lithostratigraphic (groups) and chronostratigraphic (stages) features that are still used in some present-day contributions (Fig. 3). The presence of limestone interbeds in the "Upper Alcudian" led Crespo \& Tamain (1971) and Tamain $(1972,1975)$ to define the "Hinojosas Series" in the vicinity of the homonymous village. Further subdivisions of the "Lower Alcudian" were proposed by García-Hidalgo (1988, 1993a, b) and refined by Pieren Pidal (2000), both in the Alcudia Anticline and the neighbouring Extremenian Anticlinorium. The latter author subdivided the "Lower Alcudian", from bottom to top, into (i) the La Coronada Shales, (ii) the Sta. María de Zújar Greywackes and Conglomerates, (iii) the Orellana matrix-supported Conglomerates, and (iv) the Orellanita Conglomerates, Sandstones and Shales with subsidiary limestone interbeds. In the Alcudia Anticline, the "Upper Alcudian" was formally subdivided by Pieren \& García Hidalgo (1999) and Pieren Pidal (2000), from bottom to top, into the Tamujar, Hinojosas, Cabezarrubias, San Lorenzo Conglomerates and "Upper Shaly" formations (Fig. 3).

In the 1980s, and due to the geostrategic interest in the global phosphate rock market, the Spanish administration instigated the HESPERICA Project, led by the Spanish Geological Survey (IGME) and MAYASA Co., to estimate the phosphate ore reservoirs in central Spain. The study area comprised about $54,000 \mathrm{~km}^{2}$ of surface throughout the Central Iberian Zone. Five sectors received special attention: Fuenteaguinaldo (Salamanca province), Robledo del Mazo (Toledo) and Abenójar, Horcajo de los Montes and Fontanarejo (Ciudad Real). The latter yielded an estimate of ore resources close to $5,800,000$ tons with an averaged content of about 22.7 wt. $\% \mathrm{P}_{2} \mathrm{O}_{5}$. Some results were published in meeting proceedings and geological maps, such as Álvarez-Nava \& Robles Casas (1988), Robles \& Álvarez-Nava (1988), Calvet Alonso \& Salas (1988), Pardo Alonso \& Robles Casas (1988), Nozal Martín et al. (1988a, b, c) and Ortega Gironés et al. (1988); for a historical reappraisal, see López Díaz (1994) (Fig. 3). These contributions followed a common stratigraphic sketch. In the Valdelacasa Anticline, the "Valdelacasa Group" included, from bottom to top, the Fuentes Olistostrome, the Pusa Shales, the Azorejo Sandstone and the Navalucillos Limestone formations, the two latter then considered as Cambrian due to the presence of chronostratigraphically significant ichnofossils in the former and archaeocyaths in the latter (e.g., San José et al., 1974; Gil Cid et al., 1976; Perejón et al., 1976, 1981; Zamarreño et al., 1976). Underlying the "Valdelacasa Group", they coined the term "Domo Extremeño" for the stratigraphically lowermost beds cropping out particularly in the areas of Las Hurdes, the Extremenian Anticlinorium and the Alcudian valley. In the Valdelacasa Anticline, they included rocks attributed to the "Estomiza and Cubilar" formations. In this scheme, the Estomiza Formation was envisaged to be in faulted contact with overlying rocks and should represent the lowermost stratigraphic part. This part of the succession, also attributed to the Cíjara Formation in other studies (Palacios Medrano, 1989), bears simple trace fossils and is clearly earlier than any rocks attributed to the "Lower Alcudian" in the Alcudia Anticline. A carbonate-bearing succession overlying the Domo 

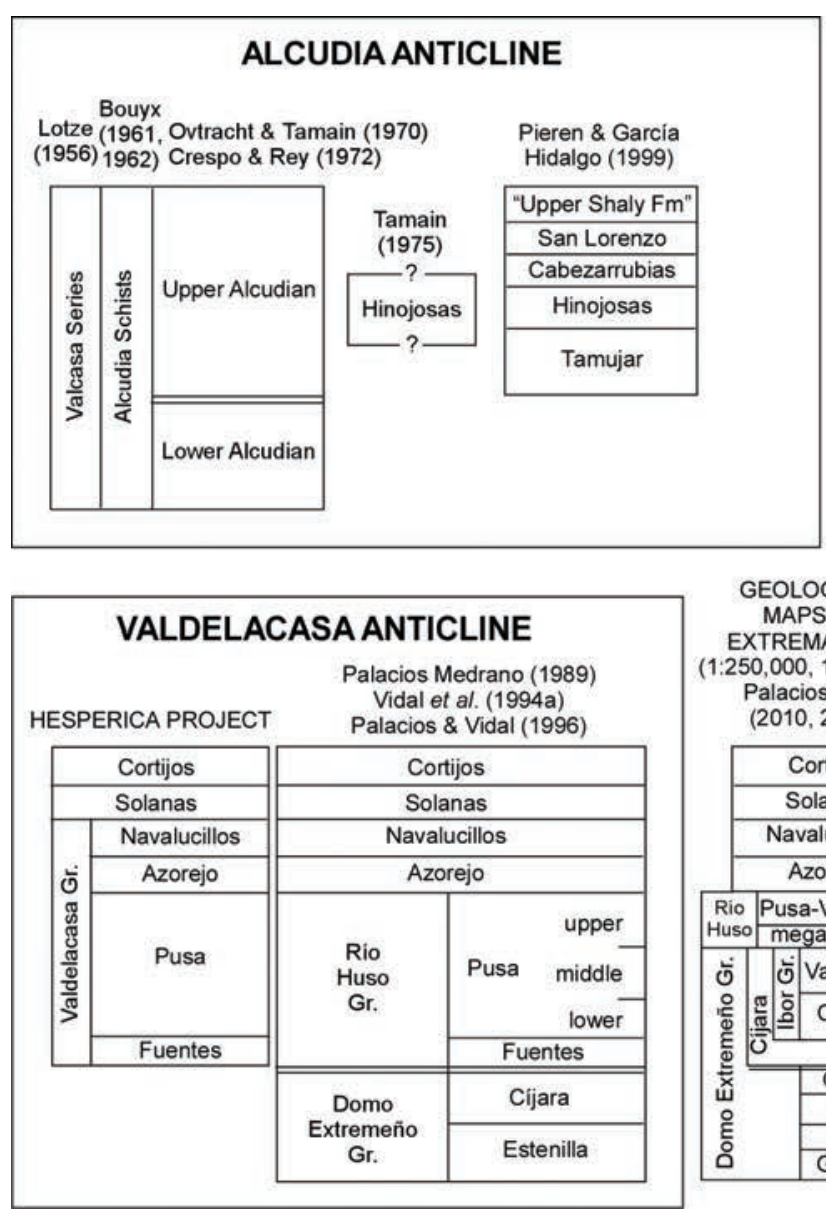

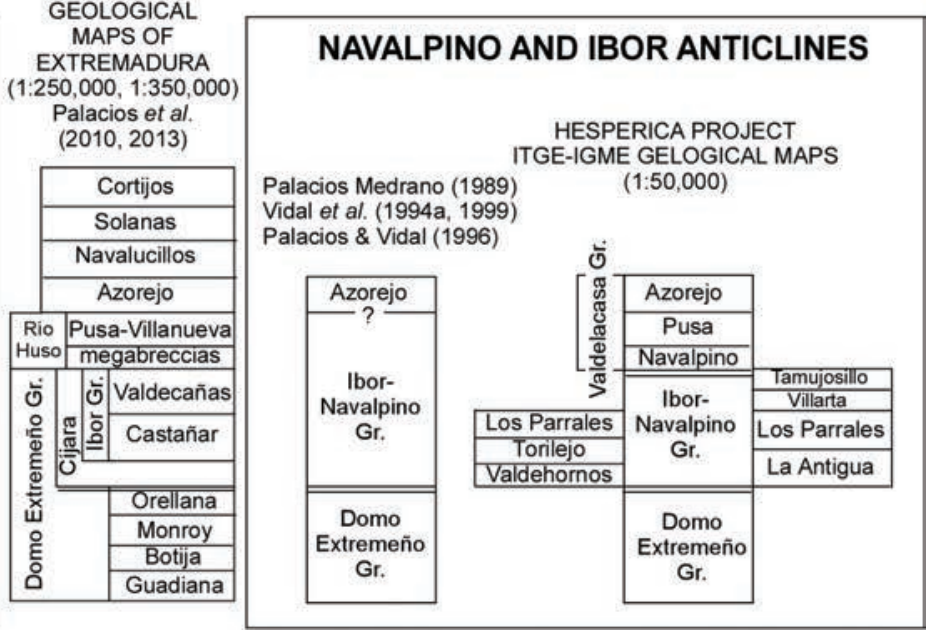

Fig. 3-Stratigraphic modifications of nomenclature and correlations in the Ediacaran-Terreneuvian of the Alcudia, Valdelacasa, Navalpino and Ibor anticlines and the southeastern edge of the Extremenian Anticlinorium, from the 1960 to 2013; Hespérica Project (from Álvarez-Nava Oñate et al., 1988 to López Díaz, 1994); ITGE-IGME Geological maps 1:50,000 and references within (e.g., Ransweiller, 1968; Rölz, 1975; Roiz, 1979; Nozal Martín et al., 1988a, b; Roiz \& Vegas, 1980; Nozal Martín, 1985; Monteserín López \& Pérez Rojas, 1987; Quesada et al., 1987; Monteserín López et al., 1989; Nozal Martín \& Martín Serrano, 1989; Nozal Martín et al., 1988a, b, c; Olivé Davó et al., 1989a, b; Piles Mateo et al., 1989).

Extremeño Group was distinguished as the Ibor or Ibor-Navalpino groups, which is particularly well represented in the Navalpino and Ibor anticlines (Álvarez Nava et al., 1988; Nozal Martín et al., 1988a, b, c). The Ibor-Navalpino Group was subdivided, following San José (1984), into several lithostratigraphic subunits: the La Antigua Conglomerate, Los Parrales Shale, Villarta Limestone and Tamujosillo Shale and Greywacke formations; in the surroundings of Torilejo village, two subunits were added: the Valdehornos Rhythmite and the Torilejo Conglomerate and Shale (Fig. 3).

The stratigraphic subdivision of the Navalpino Anticline was proposed by San José (1984), who distinguished the "Lower Alcudian", "Upper Alcudian" and "Pusian" units, the two latter separated by the Navalpino Olistostrome. In the stratigraphic synthesis of the Central
Iberian Zone, San José et al. (1990) maintained the triad "Lower Alcudian", "Upper Alcudian" and "Pusian", but considered them as megasequences obviating their former litho- and chronostratigraphic significance.

Another source of stratigraphic nomenclature was developed by the joint collaboration of the universities of Extremadura (Badajoz, Spain) and Uppsala (Sweden). Palacios Medrano (1989), Vidal et al. (1994a, b) and Palacios \& Vidal (1996), among others, subdivided the Domo Extremeño Group into the Estenilla and Cíjara formations, maintained the Ibor Group in the Navalpino-Ibor anticlines, and proposed the Río Huso Group to include the Fuentes Olistostrome and the Pusa Shales.

Finally, the geological maps of the area attest the above-reported proliferation of litho- and chronostratigraphic nomenclature. The Spanish Geological Survey 
(ITGE-IGME) mainly followed the stratigraphic subdivision proposed by the HESPERICA Project, somewhat mixing the nomenclature of the Valdelacasa and Navalpino anticlines (Fig. 3), whereas the regional Maps of Extremadura at 1:250,000 and 1:350,000 scales (Palacios et al., 2010, 2013) modified the Domo Extremeño and Río Huso concepts, proposing further subdivisions based on regional lithological modifications.

The stratigraphic subdivision proposed below intends to offer a solution for such a mixture of litho- and chronostratigraphic and megasequence terminology, maintaining the lithostratigraphic terms that have not suffered from excessive conceptual changes.

\section{Stratigraphic framework and sedimentary environments}

Based on the above-reported historical revision, the Ediacaran-Terreneuvian can be subdivided in the Alcudia valley and the Toledo Mountains into several lithostratigraphic units bounded by major gaps, which are, from bottom to top: (i) the Lower Alcudian-Domo Extremeño Supergroup, (ii) the Ibor Group and its laterally correlative Cíjara Formation, the former group capped by (iii) the Fuentes, Membrillar and Navalpino megabreccia beds and (iv) the Pusa Formation, whereas the Cíjara Formation is overlain by (v) the San Lorenzo and Fuentepizarra formations. Following the rules of the International Stratigraphic Guide (Salvador, 1994; Murphy \& Salvador, 1998), the stratigraphic framework proposed below highlights stratigraphic packages of similar lithological composition, separated by regional unconformities or major hiatuses (Figs. 4-5).

\section{Lower Alcudian-Domo Extremeño Supergroup (new)}

The Lower Alcudian-Domo Extremeño Supergroup represents both (i) the "Lower Alcudian" Group, Stage and megasequence of Ovtracht \& Tamain (1970), Herranz et al. (1977) and San José et al. (1990); and (ii) the lower part (underlying the Cadomian gap) of the widely used "Domo Extremeño" Group of Álvarez Nava et al. (1988). Both terms have been widely used and their conceptual modifications in time are not too significant. We propose the Alcudia valley as type area for the supergroup. Its base is not identified and its thickness is broadly estimated to be more than $6 \mathrm{~km}$. The supergroup mainly consists of monotonous shales and greywackes with subsidiary sandstone (lower part) and includes clast- and matrixsupported conglomerate and breccia interbeds (upper part), and scattered centimetre-scale carbonate nodules and layers. Clasts from these conglomerates and breccias are polymictic and include intraformational (mainly greywacke and shale) and exotic (e.g., lydite, quartzite, gneiss and granite) clasts, locally associated with debris derived from pegmatite and vein-quartz remains; many exotic clasts carry internal deformation fabrics.

The lower part of the Lower Alcudian-Domo Extremeño Supergroup corresponds to both the La Coronada and Sta. María de Zújar formations of García Hidalgo et al. (1993) and Pieren Pidal (2000), and to the Guadiana, Botija, Monroy and lower part of the Orellana formations sensu Palacios et al. (2010, 2013). Due to their lateral equivalence, the Guadiana Formation should be considered as a group subdivided into the La Coronada and Sta. María de Zújar formations. The upper part of the supergroup includes the Orellana Formation of García Hidalgo et al. (1993) and Pieren Pidal (2000), which corresponds to the upper part of the "Orellana" Formation of Palacios et al. (2010, 2013). In order to avoid the conceptual changes associated with the Orellana toponymy, we propose that the Campanario Group should be considered as the upper part of the supergroup, subdividing it into the Botija, Monroy and Orellana formations.

\section{A. Guadiana Group ("Guadiana Shales” sensu Herranz et al., 1977)}

The Guadiana Shales sensu Herranz et al. (1977), up to $3600 \mathrm{~m}$ thick, comprise a monotonous succession of shales and fine- to coarse-grained greywackes, locally including subsidiary pebbly shaly lenses (Fig. 6A-E). Its type area is defined along the La Coronada and Campanario villages. The group is subdivided into the La Coronada and Sta. María de Zújar formations.

The La Coronada Formation (Pieren Pidal, 2000) is a monotonous succession composed of medium- to finegrained greywackes and subsidiary shales, up to 3000 $\mathrm{m}$ thick. Its main sedimentary structures are Bouma sequences $\mathrm{T}_{\mathrm{be}}, \mathrm{T}_{\mathrm{ce}}$ and $\mathrm{T}_{\mathrm{de}}$ reflecting the progressive progradation of distal turbidite lobes (Pieren Pidal, 2000). Its stratotype lies along the road that links La Coronada and Campanario villages (GPS coordinates: N38 $54^{\prime} 43^{\prime \prime}$, W5'39'49.35"').

The Sta. María de Zújar Formation (Pieren Pidal, 2000), about $600 \mathrm{~m}$ thick, consists of massive, mediumto coarse-grained greywackes and subsidiary microconglomerates and shales, which display common $\mathrm{T}_{\mathrm{ae}}$ Bouma sequences and "disorganized facies" (a term widely used in the regional bibliography referring to mélanges rich in slumping and matrix- and clast-supported breccia deposits) reflecting progradational slope-related fans 


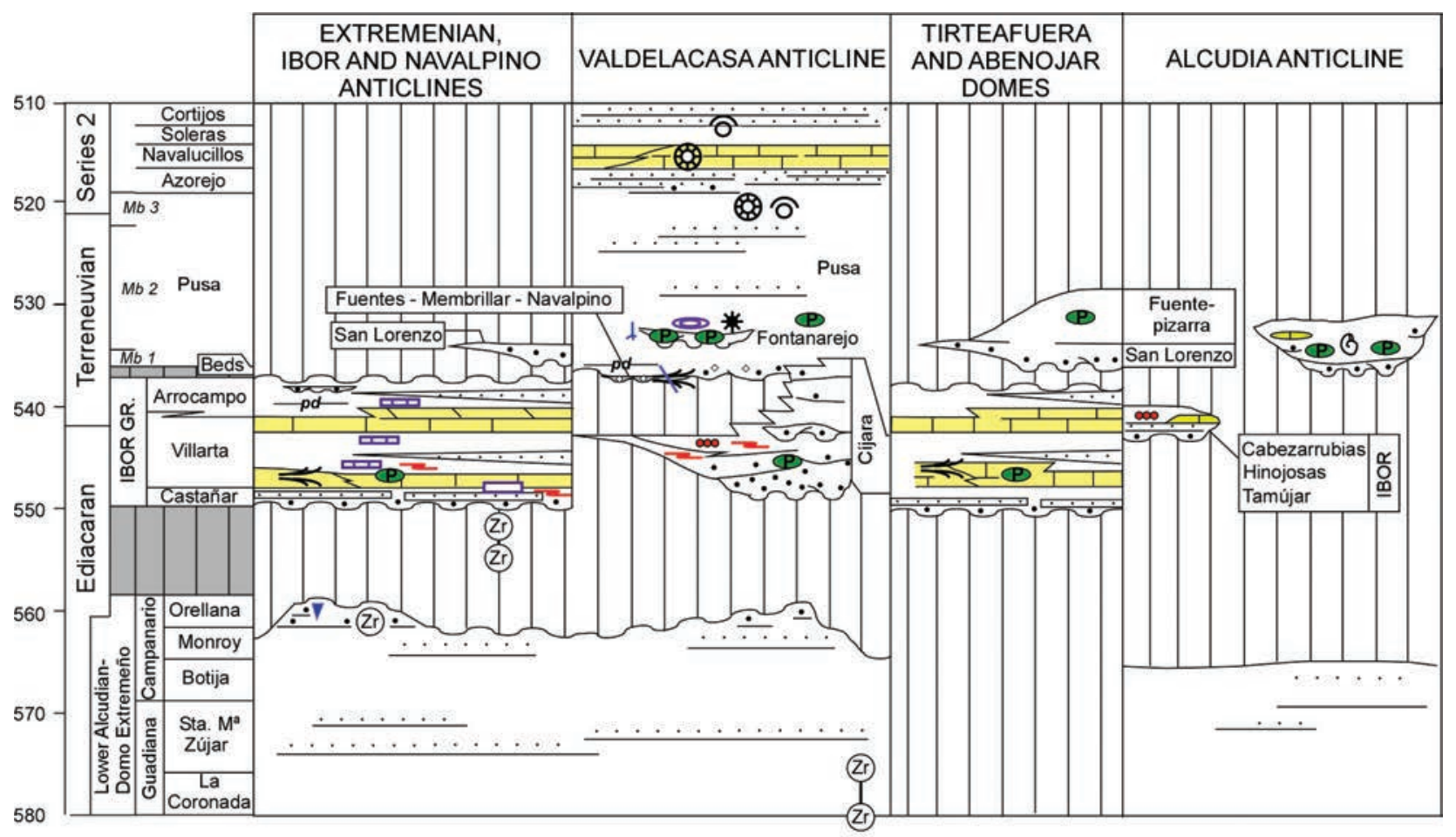

(2r)-(2i) geochronological range of detrital zircons (Talavera et al., 2012, 2015; Linnemann et al., 2018)

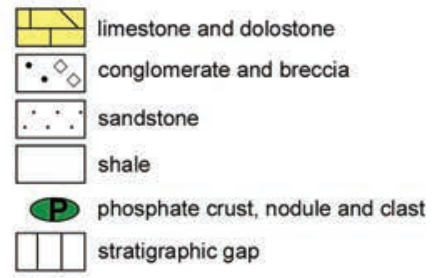

me: metamorphic event (Sardoal Complex)

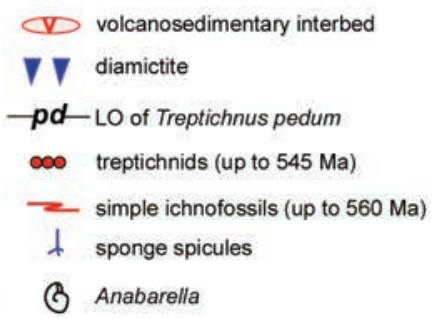

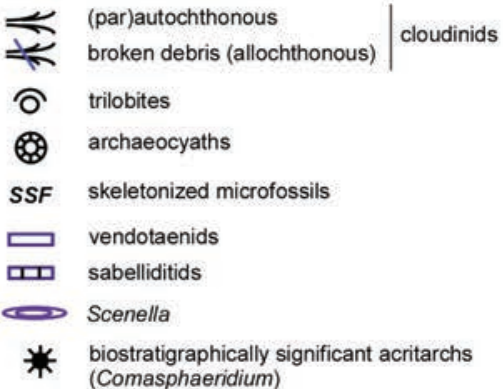

Fig. 4-Schematic stratigraphic relationships of the Ediacaran-Terreneuvian in the Alcudia, Valdelacasa and Navalpino-Ibor anticlines, the Abenójar-Tirteafura domes and the southeastern edge of the Extremenian Anticlinorium, using chronostratigraphy as vertical scale and highlighting stratigraphic gaps.

and proximal turbidite lobes, episodically interrupted by unconsolidated event beds (Pieren Pidal, 2000). The stratotype lies along the service road that follows the Zújar River valley (GPS N3859’00', W5³8'30).

Fuenlabrada et al. (2016) analyzed major and trace elements, REE, and Sm-Nd isotopes of greywacke samples from this formation. Their geochemical results point to an active margin setting as the most likely source for deposition. Trace element diagrams of the Ediacaran greywackes indicate a clear affinity to a continental island arc. The basin in which these deposits were laid down was not a part of the arc: the eroded arc was the source but the depocenter was a foreland (retro-arc) basin; a characterization of the pre-Cadomian Sm-Nd isotopes from the neighbouring Ossa-Morena Zone occurs in Rojo-Pérez et al. (2019).

In the Alcudia Anticline, the presence in the supergroup of the acritarchs Orygmatosphaeridium sp. and Protosphaeridium sp. was reported by Mitrofanov \& Timofeiev (1977; unpublished report cited in San José, 1984), which has been traditionally used to date the supergroup as "Riphean-early Vendian". However, these acritarchs no longer have biostratigraphic value (e.g., Vidal et al., 1994b; Liñán \& Palacios, 1982). Simón (2017) reported the trace fossil Torrowangea aff. rosei and possible Ediacara-type holdfasts from "Lower Alcudian" strata of the Alcudia Anticline. However, the 


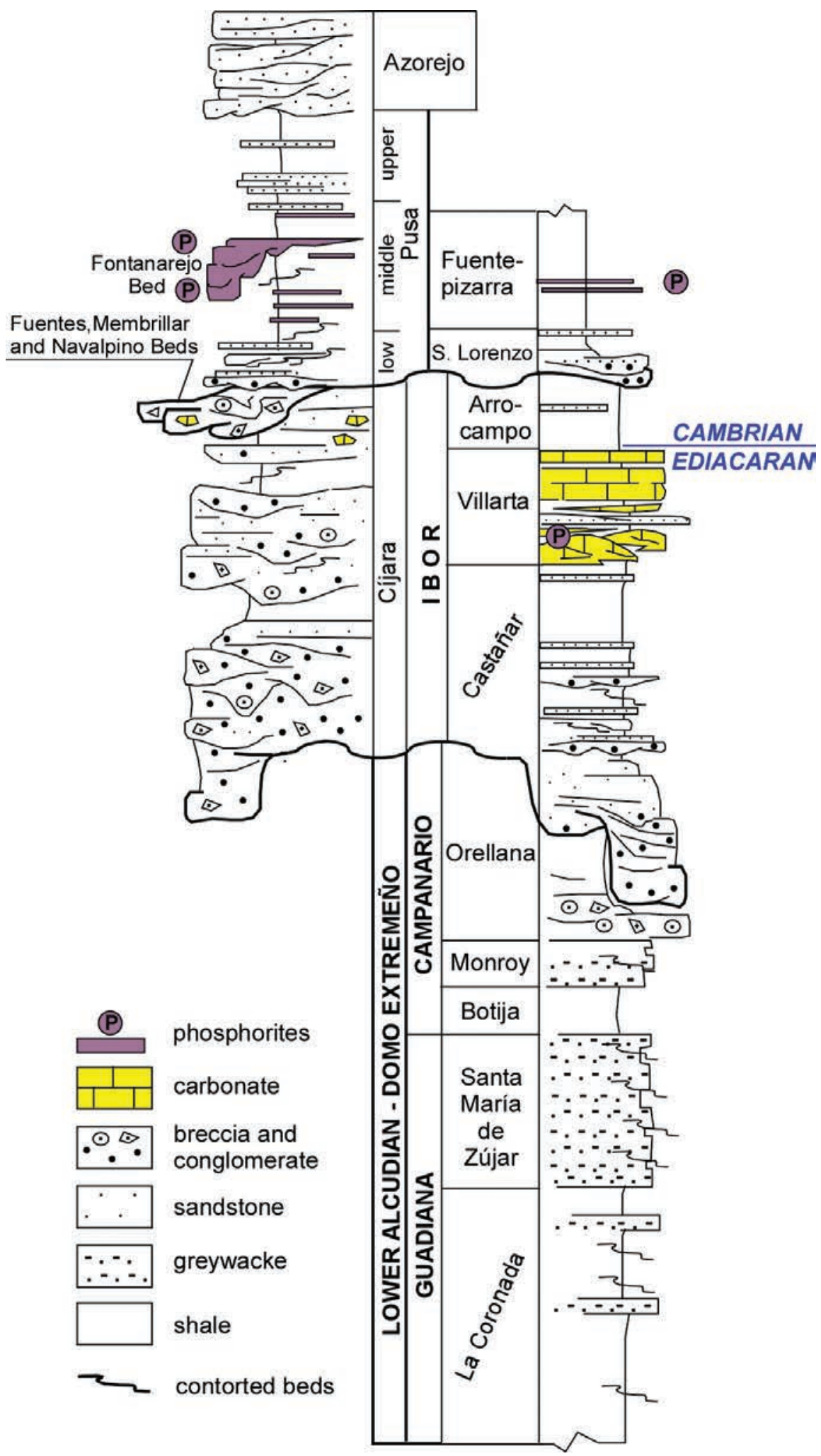

Fig. 5-Schematic stratigraphic log of the Ediacaran-Terreneuvian in the Alcudia, Valdelacasa and Navalpino-Ibor anticlines and the southeastern edge of the Extremenian Anticlinorium; vertical axis not to scale; in blue, tentative setting of the Ediacaran-Cambrian boundary based on ichnofossils. 
discoidal structure is insufficiently diagnostic to allow any confident identification, and the biogenicity of the trace fossils is uncertain. A small looping structure described from the Membrio area (Vidal et al., 1994a) within the Guadiana Formation of Palacios et al. (2013) is probably biogenic, but could be either a trace or a filamentous fossil.

The Guadiana toponymy has been used abusively to define the Messinian "Guadiana sands Formation" (Andalucía Group) infilling the Guadalquivir-Gulf of Cádiz Tertiary Basin (Serrano Oñate et al., 1984; Riaza \& Martínez del Olmo, 1996), which did not take in account the previous definition of the Ediacaran "Guadiana Shales" by Herranz et al. (1977).

\section{B. Campanario Group (new)}

The Campanario Group conformably overlies the Sta. María de Zújar Formation. Its stratotype lies along the road from Campanario village to the Zújar River (GPS: N38 55'40", W5'36'00"). According to Pieren Pidal (2000), the Orellana Formation, conformably ovlerying the Sta $\mathrm{M}^{\mathrm{a}}$ de Zújar Formation, was originally subdivided into a lower monotonous part of shales and greywackes and an upper part of matrix-supported conglomerates. Subsequently, Palacios et al. $(2010,2013)$ maintained the Orellana Formation for the upper part of Pieren Pidal's (2000) homonymous unit, which is retained in this revision, and distinguished the Botija Shales and the Monroy Greywackes as separate formations conformably underlying the aforementioned matrix-supported conglomerates. As a result, the Campanario Group is subdivided by us into the Botija, Monroy and Orellana formations.

The Botija Formation (Palacios et al., 2010), up to $250 \mathrm{~m}$ thick, is a monotonous shaly succession with subsidiary sandstone interbeds. Its stratotype lies along the road and paths linking Botija and Torremocha villages (GPS: N39²1'27.53", W6º'2.67").

The Monroy Formation (Palacios et al., 2010), up to $150 \mathrm{~m}$ thick, comprises a succession of alternating shales and fine- to medium-grained greywackes. Its stratotype lies along the eastern bank of the José $\mathrm{M}^{\mathrm{a}}$ Oriol reservoir (Tagus River), along the road that links La Perala and Cañaveral villages (GPS: N3942'58.41", W6'27'1.28”).

The Orellana Formation ("Orellana matrix-supported Conglomerates" sensu Pieren Pidal, 2000), up to 2000 $\mathrm{m}$ thick, consists of shales episodically comprising clast- and matrix-supported rounded-to-angular clasts embedded in shales and cross-stratified conglomerates (Fig. 6F-H). Locally these conglomerates are overlain by clast-free shales. Its stratotype lies along the banks of the eponymous dam, close to "poblado turístico" (GPS: N38'59'49', W5'31'50'”).

In the vicinity of the Orellana dam, a distinct package of matrix-supported breccias and conglomerates, belonging to the Orellana Formation, has been proposed by Linnemann et al. (2018) as representative of the socalled Weesenstein-Clanzschwitz-Orellana Glaciation. Based on detrital zircon, the maximum depositional age for these strata $(565 \pm 4 \mathrm{Ma})$ should be significantly younger than that for the Gaskiers glaciation (ca. 579 $\mathrm{Ma}$ ). This lithostratigraphic unit begins with conglomerates and coarse sandstones, wich are followed upsection by fine-grained sandstones and shales. Diamictites suggest features indicative of a glaciomarine origin, including dropstones, rainout sediments, flat iron-shaped pebbles and facetted pebbles. Pebble size varies from a few millimetres to $20 \mathrm{~cm}$ (Linnemann et al., 2018).

\section{Ibor Group (Álvarez Nava et al., 1988; Nozal Martín et al., 1988a, b, c)}

The Ibor Group is mainly recognized in the Sierra de la Zarzuela and the surroundings of the Orellana dam, the Ibor, Navalpino and Alcudia anticlines, and the Abenójar-Tirteafuera domes. It is subdivided below into the Castañar, Villarta and Arrocampo formations.

2A. The Castañar Formation ("Castañar Siltstones" of Álvarez Nava et al. 1988; Nozal Martín, 1988a, b, c; Palacios et al., 2010), up to about $400 \mathrm{~m}$, consists of shales and greywackes with minor coarse-grained sandstone-toconglomerate interbeds, and carbonate nodules and thin layers. In the surroundings of Guadalupe town, the base of the formation is marked by distinct arkosic sandstones (Palacios et al., 2013). The stratotype lies along the road that links Robledollano and Castañar de Ibor (GPS: N39'37'30", W5 $25^{\prime} 46^{\prime \prime}$ ). The shale interbeds contain both Vendotaenids and simple horizontal ichnofossils. Close to Navalvillar de Ibor, Hufnagel (2008) described a greater diversity of macrophytes: "club-shaped" forms were tentatively compared with Longfengshania, although substantially smaller; a spindle-shaped form was described as Salobrigia guadalupensis and a clubshaped form as Ibora sdzuyi. This site has also yielded spirally coiled forms and rare forms branching into three.

In the Sierra de la Zarzuela and the surroundings of the Orellana dam, Pieren Pidal (1990) subdivided the strata unconformably overlying the Lower AlcudianDomo Extremeño Supergroup into several informal units, which are proposed in this study as members of the Castañar Formation. These include, from bottom to top, the Orellanita conglomerate (Fig. 7A) and the Cogolludo sandstone (Fig. 7B) members: the former, up 

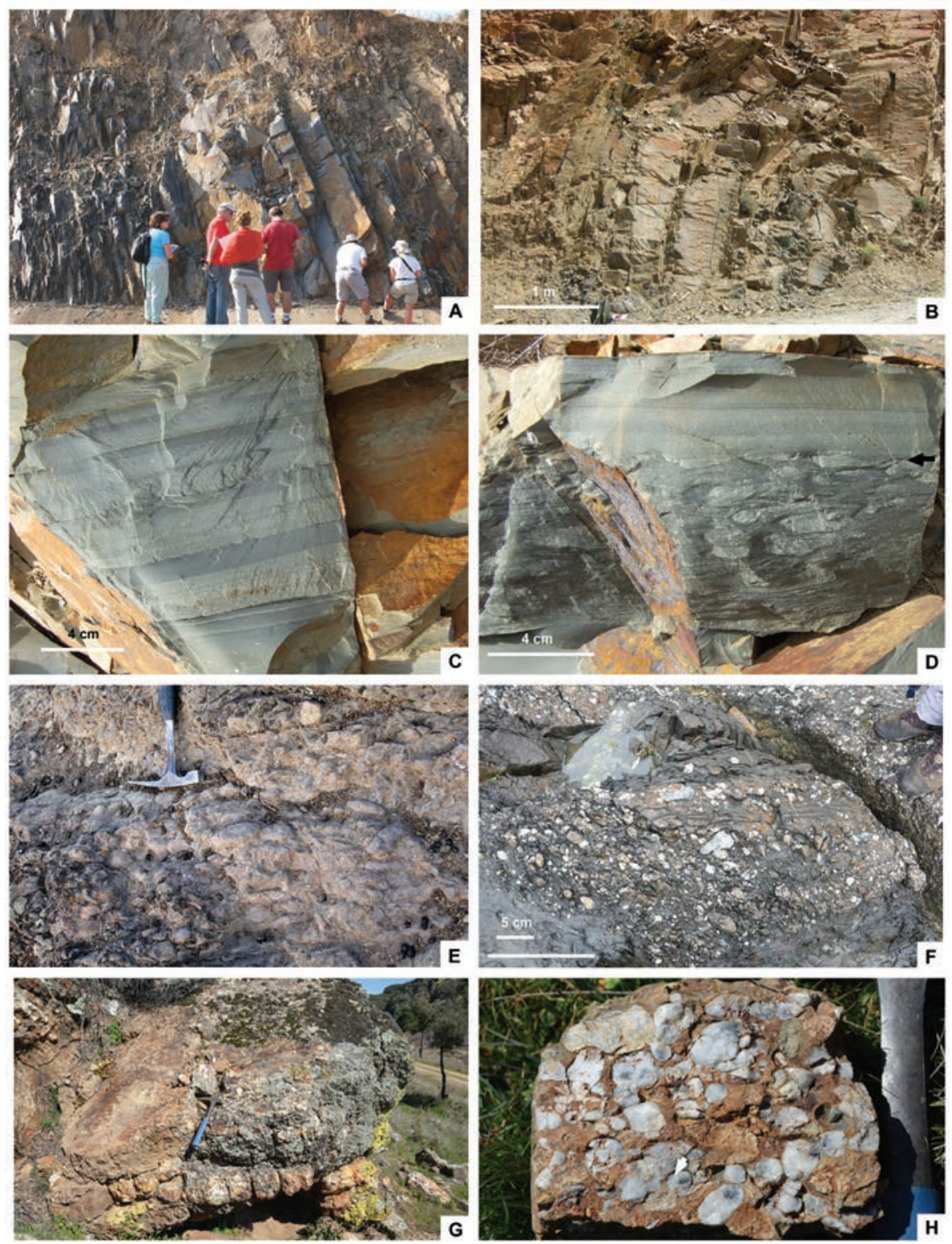

Fig. 6-Field aspect of the facies associations exhibited by the Lower Alcudian-Domo Extremeño Supergroup. A. Typical aspect of wellbedded coarse-grained and poorly bedded fine-grained greywacke alternations of the supergroup close to Valdecaballeros. B. Thickbedded coarse-grained greywackes of the Sta. $\mathrm{M}^{\mathrm{a}}$ de Zújar Formation, Salor River area. C. Siltstone/claystone laminae mimicking Bouma sequences from the La Coronada Formation, Salor River area. D. Irregular contact (arrowed) of contorted and slumped beds onlapped by monotonous shale with parallel laminae, Salor River area. E. Chaotic clast-supported conglomeratic breccia, lower part of Castañar Formation from the northern shore of the Cíjara dam, Villarta de los Montes. F. Channelized deposits of clast-supported conglomerates, capped by trough cross-stratified sandstones and scouring monotonous shaly beds; Orellana Formation at stratotype. G. Amalgamation of trough cross-stratified conglomerates and breccias, including contorted and broken hydrothermal veins and dykes, Orellana Formation at the upper part (geographically speaking) of the Estenilla River. H. Sample from previous image showing subrounded quartz vein clasts embedded in a reddish litharenitic matrix.

to $50 \mathrm{~m}$ thick, consists of amalgamated quartzarenitic conglomerates grading upward into sandstone-dominant sandstone/shale alternations, easily recognized by their variegated colours, which have been interpreted as the onset of alluvial-to-fluvial environments (Pieren Pidal et al., 1991).

In the Navalpino Anticline, the Castañar Formation has been described as the "Parrales Claystones" (San José, 

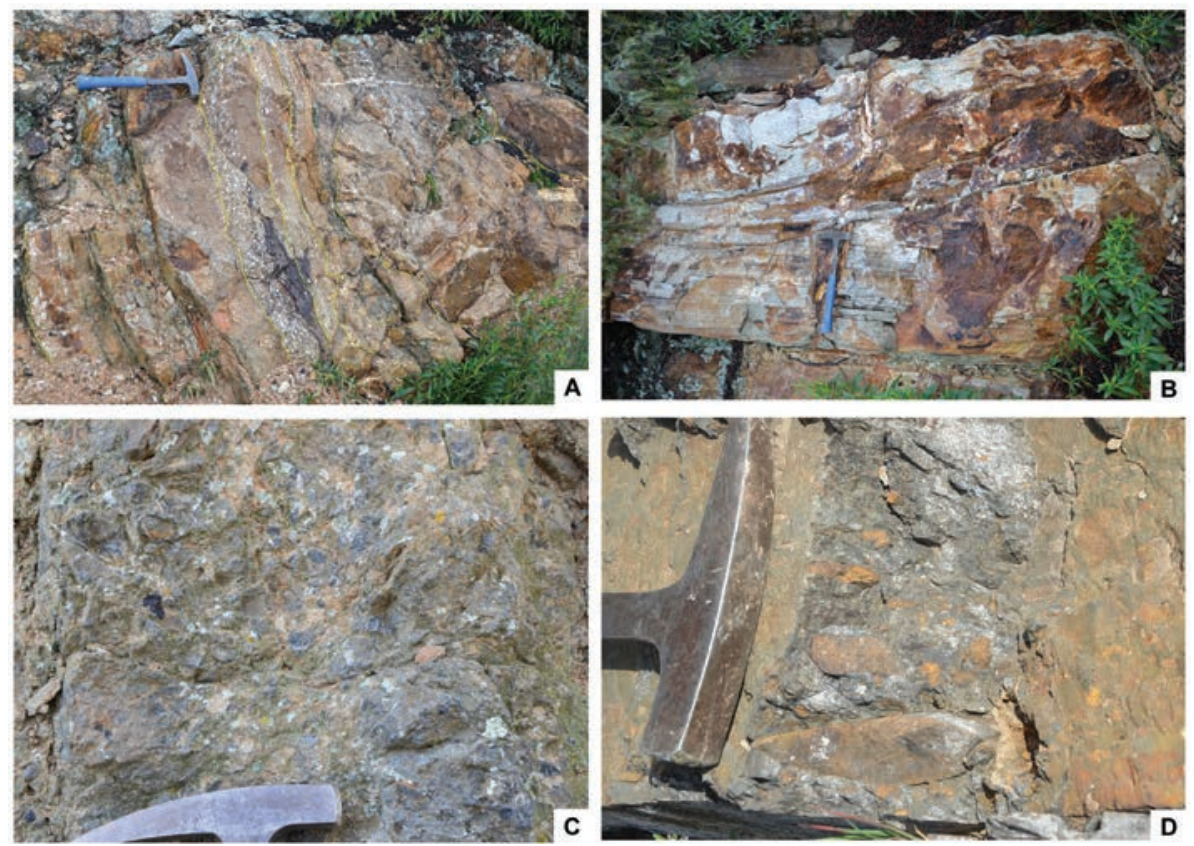

Fig. 7-Field aspect of the different facies described in the text from the Castañar Formation. A. Amalgamation of channelized conglomerates (base marked in yellow) rich in vein quartz clasts scouring pebbly sandstones; Orellanita Member close to Orellana la Vieja at Sierra de la Zazuela. B. Trough cross-stratified sandstones overlying conglomerates of previous image; Cogolludo Member, close to Orellana la Vieja at Sierra de la Zazuela. C. Unselected polymictic conglomerates from the La Antigua Member; basement of $\mathrm{N}^{\mathrm{a}}$ Sra. de la Antigua hermitage, in the vicinity of Villarta de los Montes. D. Typical conglomerates of the Castañar Formation cropping on the northern shore of the Cíjara dam, close to Villarta de los Montes.

1984), and the base of the Ibor Group is represented by the La Antigua Conglomerate (Fig. C), which is here proposed as another member.

2B. The Villarta Formation (San José, 1984; López Díaz, 1994) is a heterolithic succession, ranging from 100 to $250 \mathrm{~m}$ in thickness. In its type area, the northern shore of the Cíjara dam, close to Villarta de los Montes village, the Villarta Formation can be subdivided into three members, from bottom to top: (i) an alternation of lenticular and bedded carbonates embedded in greenish shales (Fig. 8B-C); (ii) a conglomeratic to sandstone-dominant unit passing upward to sandy dolostones (Fig. 8F); and (iii) an alternation of shales and bedded carbonates (Fig. 8H). The stratotype of the formation is located on the northern shore of the Cíjara dam, at the La Majada del Andaluz hut (GPS: N39'13'52.86”, W39'13'52.86").

Cloudinid-microbial buildups are recorded in the lower member of the Villarta Formation (Fig. 8B). These have yielded, after acid etching, specimens of Cloudina (C. carinata, C. hartmanae and probably C. xuanjiangpingensis), Sinotubulites (S. baimatuoensis) and Protolagena sp. (a problematic flask-shaped microfossil; Cortijo et al., 2010, 2015) (Fig. 9A-E). Vendotaenids are relatively common in the shale interbeds of the same member (Fig. 8G), whereas Sabelliditids are abundant in the shale interbeds of the middle member. Simple ichnofossils are scattered, except in the upper member, where they are relatively common.

The Villarta Formation is interpreted to have formed on rimmed and unrimmed carbonate platform-blocks with localized ooidal shoals (García Hidalgo, 1984; Calvet Alonso \& Salas, 1988), episodically recording phosphogenic episodes that are commonly recorded as phosphoritic crusts and clasts (Álvaro et al., 2016b). Diagenesis (mainly related to neomorphism and replacement to dolomite and magnesite) of the lower member limestone interbeds has been geochemically described and interpreted in Alonso-Zarza \& Martín-Pérez (2008), Martín-García et al. (2009, 2011, 2019), Martín-Pérez et al. (2012) and García-Guinea et al. (2013). These carbonates were the main source for the material incorporated into the megabreccia beds described below.

In the Sierra de la Zarzuela and the surroundings of the Orellana dam, Pieren Pidal (1990) distinguished a heterolithic, sandstone/shale succession, overlying the abovereported Cogolludo Sandstone Member, which comprises two distinct limestone interbeds, up to $2 \mathrm{~m}$ thick, named by the author "Loma de la Calera" (Fig. 8A) and "Collado 

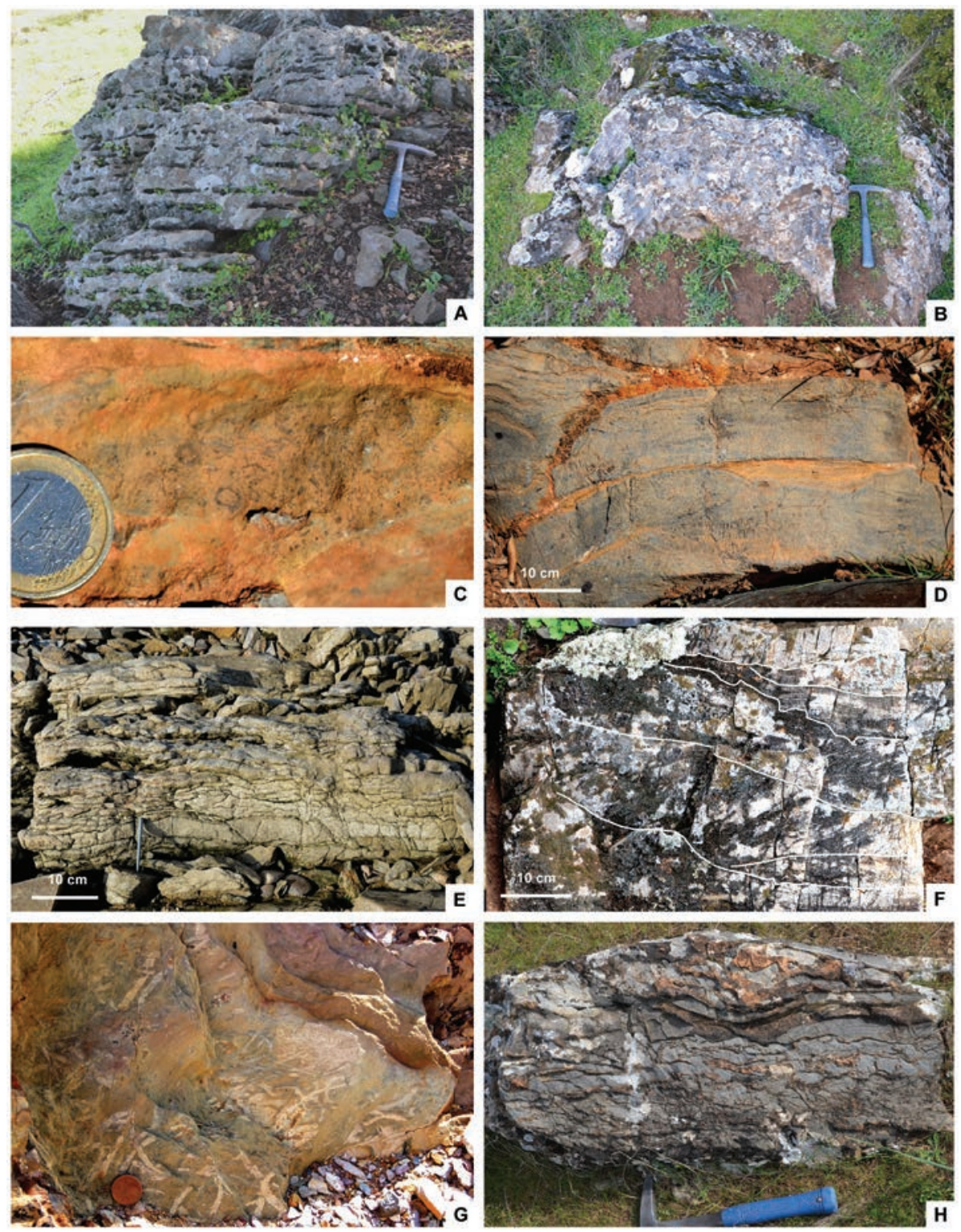

Fig. 8-Lithological and facies aspects of the Villarta Formation. A. Shale beds with centimetre-thick limestone nodules parallel to stratification of the Loma de la Calera Bed, Sierra de la Zarzuela. B. Thromboid patch-reef, with distinct flat base and convex top, lower member at the Abenójar Dome. C. Bed surface showing transverse sections of Cloudina carinata preserved upright, lower member at stratotype. D. Superposition of two thromboid layers with characteristic spotted aspect, lower member at stratotype. E. Nodular limestone from the Arrocampo section. F. Amalgamated trough cross-stratified litharenites, middle member at stratotype. G. Vendotaenids preserved in shaly interbeds, near Robledollano. H. Wavy-to-nodular limestone bed displaying partial dolomitization (orange), upper member at stratotype.

de la Liebre" limestone interbeds, in some cases passing laterally into centimetre to decimetre-scale nodules of carbonate embedded in a monotonous shale. The shales between both carbonate marker beds have yielded ichnofossils, such as Treptichnus isp. The lower limestone interbed grades laterally into the Talarrubias Dolostone Bed, up to $6 \mathrm{~m}$ thick, rich in Sabellidites and treptichnids, and represents the lower part of the Villarta Formation in the area. The limestones of the Abenójar Dome have also yielded tubular skeletal fossils including Cloudina (Vidal et al., 1994b; Zhuravlev et al., 2012; Simón, 2018).

2C. The Arrocampo Formation (new) is proposed to solve numerous structural problems, reported in previous works. Several formations have been defined in the 


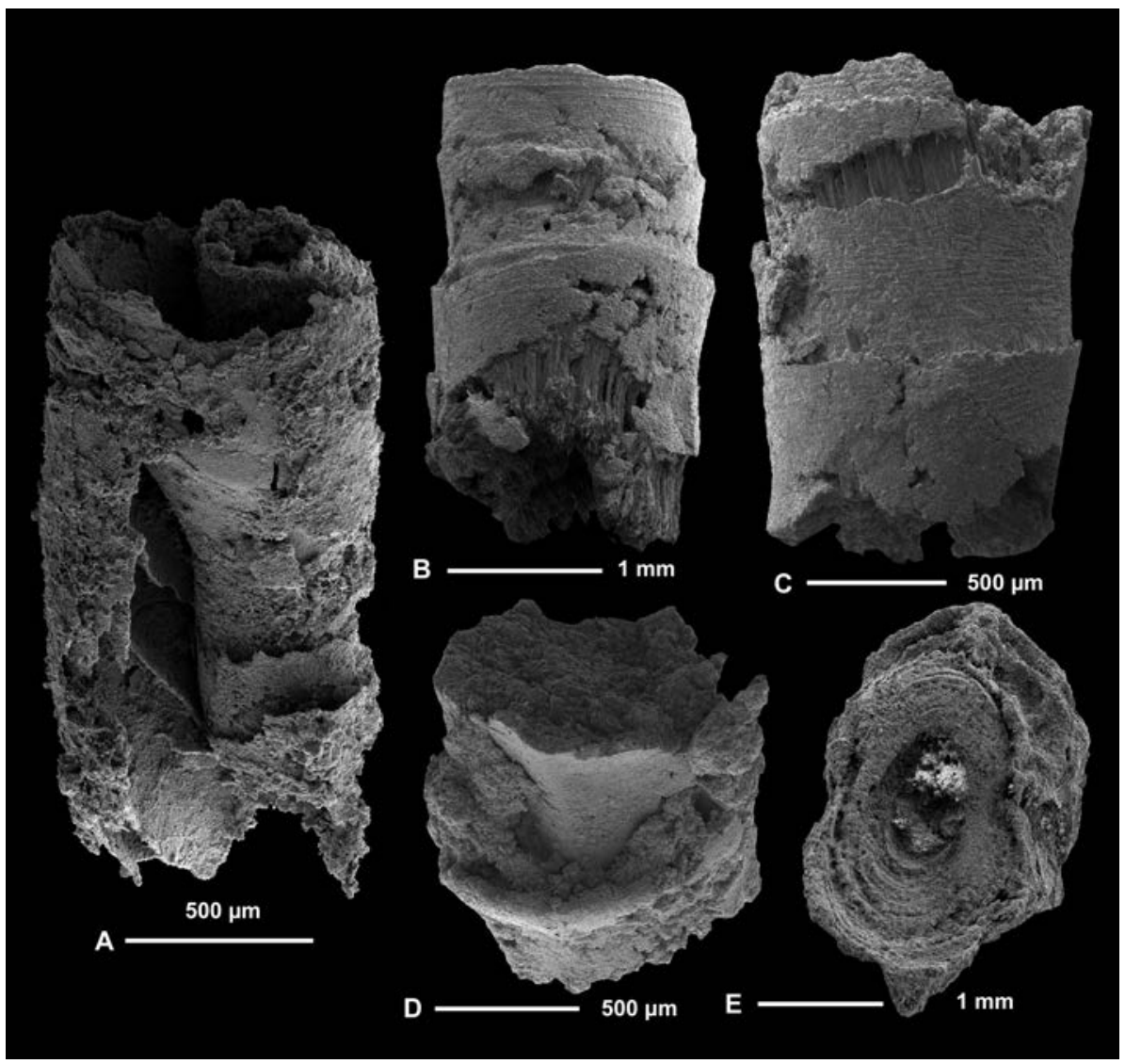

Fig. 9-Skeletonized microfossils extracted after etching from the reefs of the Villarta Formation. A. Cloudina hartmanae. B-C. Cloudina xuanjiangpingensis. D. Cloudina carinata. E. Sinotubulites sp.

literature seemingly overlying the Villarta Formation, but all of them are strongly affected by structural folds and faults that preclude any correct stratigraphic setting. As a result, we propose the Arrocampo Formation as a shale-dominated unit with subsidiary sandstone interbeds increasing upwards, and local presence of centimetrescale carbonate nodules parallel to stratification. This unit is up to $350 \mathrm{~m}$ thick, and conformably overlies the Villarta Formation. Its stratotype lies along the right bank of the Tagus River (GPS: N3946'51.13"', W5 44'48.71" ), close to the Almaraz nuclear power plant, named Arrocampo by García-Hidalgo (1985). The monoclinal outcrops of this formation are unconformably overlain by either the San Lorenzo Formation or the Lower Ordovician conglomerates and quartzites. The base of the formation contains the earliest ichnofossils assigned to Treptichnus pedum, so tentatively marking the base of the Terreneuvian.

2D. The Tamujar, Hinojosas and Cabezarrubias formations are exclusive of the Alcudia Anticline. They are laterally and lithologically equivalent to the triad Castañar Villarta - Arrocampo formations and are maintained here for practical reasons, with the aim of simplifying the stratigraphic framework. The Tamujar Formation (stratotype of "Tamujar beds" along the homonymous ravine, in the vicinity of Hinojosas village; Peláez Pruneda et al., 1988; Pieren Pidal \& Herranz Araújo, 1988; San José et al., 1990; Pieren Pidal, 2009), which unconformably overlies the Lower Alcudian-Domo Extremeño Supergroup, is up to $50 \mathrm{~m}$ thick and dominated by amalgamated sandstones with subsidiary conglomerate and shale interbeds (Pieren \& García Hidalgo, 1999) (GPS: N38³6’8”, W4¹2’23”). The Hinojosas Formation (lower part of Bouyx's "Hinojosas Series"), up to $80 \mathrm{~m}$ thick, is a heterolithic unit with carbonates, sandstones, shales and subisidiary conglomerate interbeds (GPS: N3836'33", W4¹1'43"). The Cabezarrubias Formation ("Lower Shaly Formation" of Palero, 1991, 1993; Pieren \& García Hidalgo, 1999) is a monotonous shale-dominated succession with a maximum thickness, to the South of the homonymous village, of about 120 m thick (GPS: N38³6'51', W4¹1'35.40”).

The Hinojosas Formation has yielded numerous ichnofossils, such as treptichnids (reported as Hormosiroidea $\mathrm{cf}$. 
canadensis), Monomorphichnus lineatus (García-Hidalgo, 1993a, b) and, from a section probably attributable to this unit, bilobed trace fossils with a circling motion (Pieren Pidal, 2000), assigned to Taphrhelminthopsis circularis by Fernández Remolar et al. (2005). In the Cabezarrubias Formation, García-Hidalgo (1993b) reported the presence of Bergaueria aff. langi and Planolites sp. Simón (2017) reported additional trace fossils from the Hinojosas and Cabezarrubias formations including a centimetre-wide trace fossil from the Hinojosas Formation that was tentatively compared with Psammichnites.

\section{Cíjara Formation (modified from Palacios Medrano, 1989)}

The Cíjara Formation was initially described by McDougall et al. (1987) as a siliciclastic "member" unconformably overlying the Lower Alcudian-Domo Extremeño Supergroup, but including the lower part of the unconformably overlying Lower-Ordovician Skolithosbearing "Purple Series". Subsequently, Palacios Medrano (1989) proposed the restriction of the Cíjara Formation to the pre-Ordovician part. According to the author, the heterolithic formation, up to $1400 \mathrm{~m}$ thick, consists of conglomerates, sandstones and subsidiary shales, phosphatic crusts and clasts, which commonly infill interbedded channelized conglomerates (Álvaro et al., 2016b) (Fig. 10A-H). Its stratotype is proposed along the Estenilla River (GPS: N39²3'48.58', W4'51'49.78'), where both the base and top are observable.

The Estenilla Formation, defined by Palacios Medrano (1989) in the geographically upper part of the homonymous valley, represents two units: (i) the lower "member" displays the lithology and facies associations characteristic of the above-reported Orellana Formation, and is not retained in this work; whereas (ii) the upper part comprises the shales that mark the top of the Orellana Formation and the basal part of the Cíjara Formation, in the sense proposed here. An analysis of sulphur isotopes made in the Estenilla Formation by Strauss (2002) yielded organic carbon contents between $<0.1$ and $1.0 \mathrm{wt} \%(\mathrm{n}=67)$ and sulphide sulphur abundances between $<0.1$ and $5.9 \mathrm{wt} \%$ $(\mathrm{n}=83$ ). Resulting $\mathrm{S} / \mathrm{C}$ ratios range from 0.1 to 7.1 , with a few values substantially higher. DOP values are $<0.40$. $\delta^{34} \mathrm{~S}$ values between -17.4 and $+49.3 \%$ o $(n=14)$ characterize pyrite between +32.4 and $+49.3 \%$. A most prominent feature is the positive correlation between organic carbon and sulphide sulphur, and high $\mathrm{S} / \mathrm{C}$ ratios pointing to overabundance of sulphur over organic carbon.

The Cíjara Formation has yielded bacterial acritarchs attributed to Bavlinella faveolata (=Sphaerocongregus variabilis Moorman, 1974) and Palaeogomphosphaeria cauriensis Palacios Medrano (1989). Ichnofossils are represented by simple horizontal forms such as Gordia marina and Helminthoidichnites (for discussion on identification, see Jensen \& Palacios, 2016). Possible treptichnids have been reported from this unit (Vidal et al., 1994b; Jensen, 2003), but it remains unclear if these represent trace fossils with multiple outlets or a vertical sinusoidal movement (cf. Jensen et al., 2006).

The Cíjara Formation includes numerous sloperelated event deposits characterized by the presence of tool, bounce and flute marks, and common channelized deposits associated with slumps and olistostromes. The presence of limestone clasts, reflecting episodes of carbonate production in laterally equivalent areas, suggests the contemporaneous deposition of the Villarta Formation during the sedimentation of parts of the Cíjara Formation. The abundance of coeval fracturing and fissuring in a substrate submitted to episodic uplift, tilting and rotation of blocks is highlighted by the abundance of hydrothermal veining and reworking of their vein quartz clast counterparts.

\section{Fuentes, Membrillar and Navalpino megabreccia beds}

The Cíjara/Pusa contact is locally marked by the onset of megabreccia beds: the Fuentes Bed in the Valdelacasa Anticline (Cortázar, 1878a, b), and the Navalpino and Membrillar Beds in the Navalpino Anticline (Moreno Serrano, 1974; Moreno, 1975, 1977a, b; López Díaz, 1992, 1994). The beds, up to $200 \mathrm{~m}$ thick, consist of clastsupported, unsorted conglomerates and gravel sandstones that display drastic changes in thickness (Fig. 11A-D). Their blocks, which can reach $2 \mathrm{~m}$ in size, are composed of limestone, dolostone, sandstone, shale and conglomerate, and are crosscut by networks of quartz veins. The larger blocks are commonly subrounded, whereas the smaller ones are (sub)angular in shape.

The megabreccia beds have been previously interpreted as gravitational slides triggered by "seismoevents" (e.g., Moreno, 1975, 1977a, b; Santamaría Casanovas \& Remacha Grau, 1994). Although these chaotic deposits have been traditionally interpreted as "olistostromes" (a term that refers to accumulation as a semifluid body by submarine gravity sliding or slumping of unconsolidated sediments), they represent indeed submarine fan and slope-apron deposits whose sub-units can show overlapping geometries.

The age of these beds is constrained by the fossiliferous content of their allochthonous blocks. In the Membrillar Bed, Palacios (1983) reported the presence of the acritarchs Bavlinella faveolata Shepeleva, 

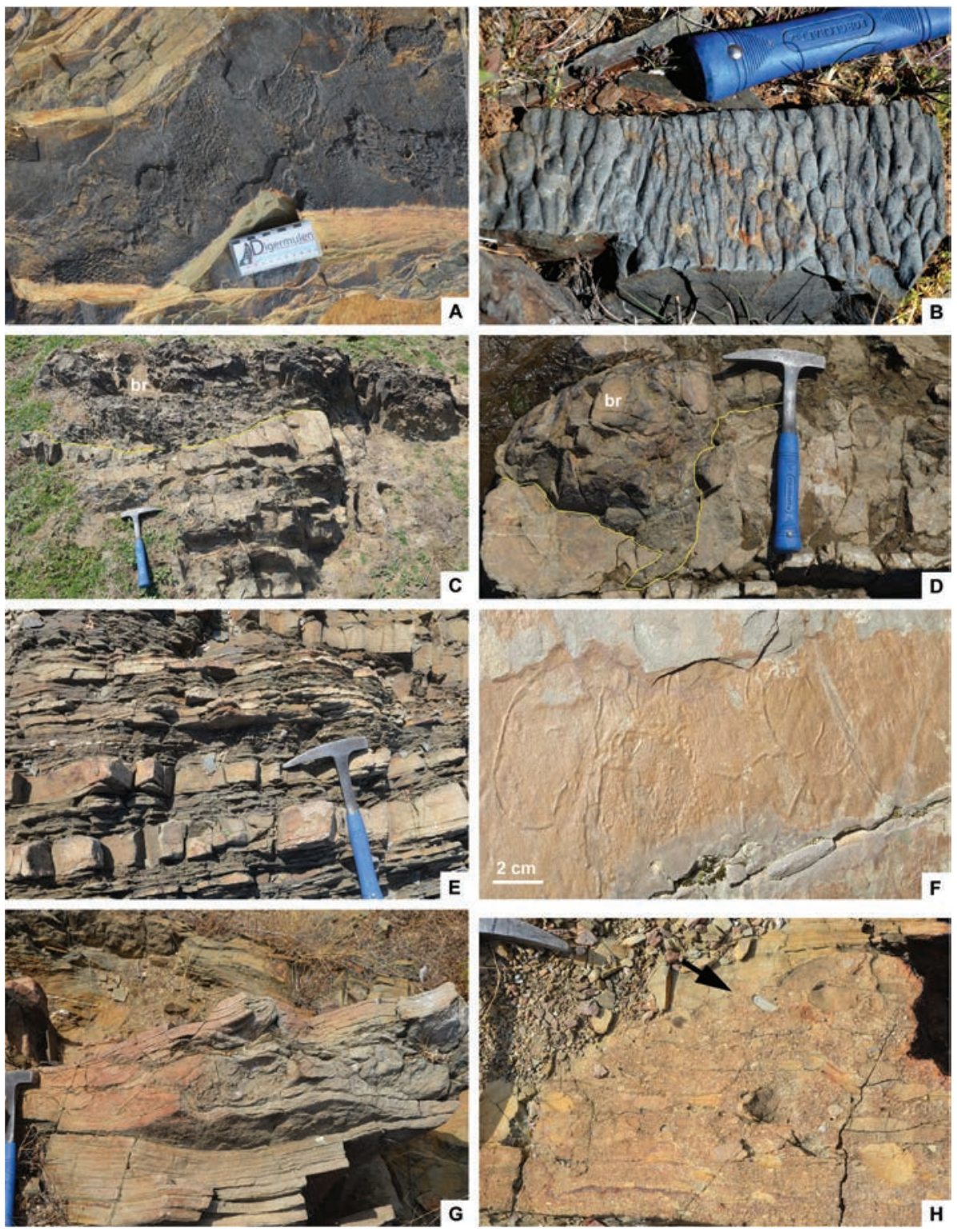

Fig. 10-Macroscopic features of the Cíjara Formation, all taken from the Estenilla River stratotype. A. Microbially induced sedimentary structures on the surface of a siltstone. B. Flute structures. C-D. Channellized structures scouring sandstone/shale alternations, and infilled with breccia deposits ("disorganized facies"). E. Sandstone/shale alternations, the latter containing ichnofossils. F. Example of ichnofossil loops preserved in convex hyporelief. G. Slumping bed sandwiched between two undeformed beds. H. Conglomeratic infill of a channel including limestone (arrowed) clasts.

1962 and Trachysphaeridium laufeldi? Vidal, 1976. Subsequently, Palacios (1983) and Palacios Medrano (1989) dismissed the presence of T. laufeldi? and reported the presence of the acritarch Bavlinella faveolata Shepeleva, 1962, whereas Brasier et al. (1979) and Brasier \& Cowie (1989) highlighted the occurrence of Planolites isp. in shale interbeds. In the Membrillar
Bed of the Valdelacasa Anticline, Palacios Medrano (1989) reported the presence of Cloudina shells within reworked blocks of the megabreccia (Fig. 11E). The mixture of heterolithic clasts sourced from different Ediacaran-bearing fossiliferous sources point to the incorporation of polyphase blocks, sourced from underlying formations, in slope-apron deposits. 

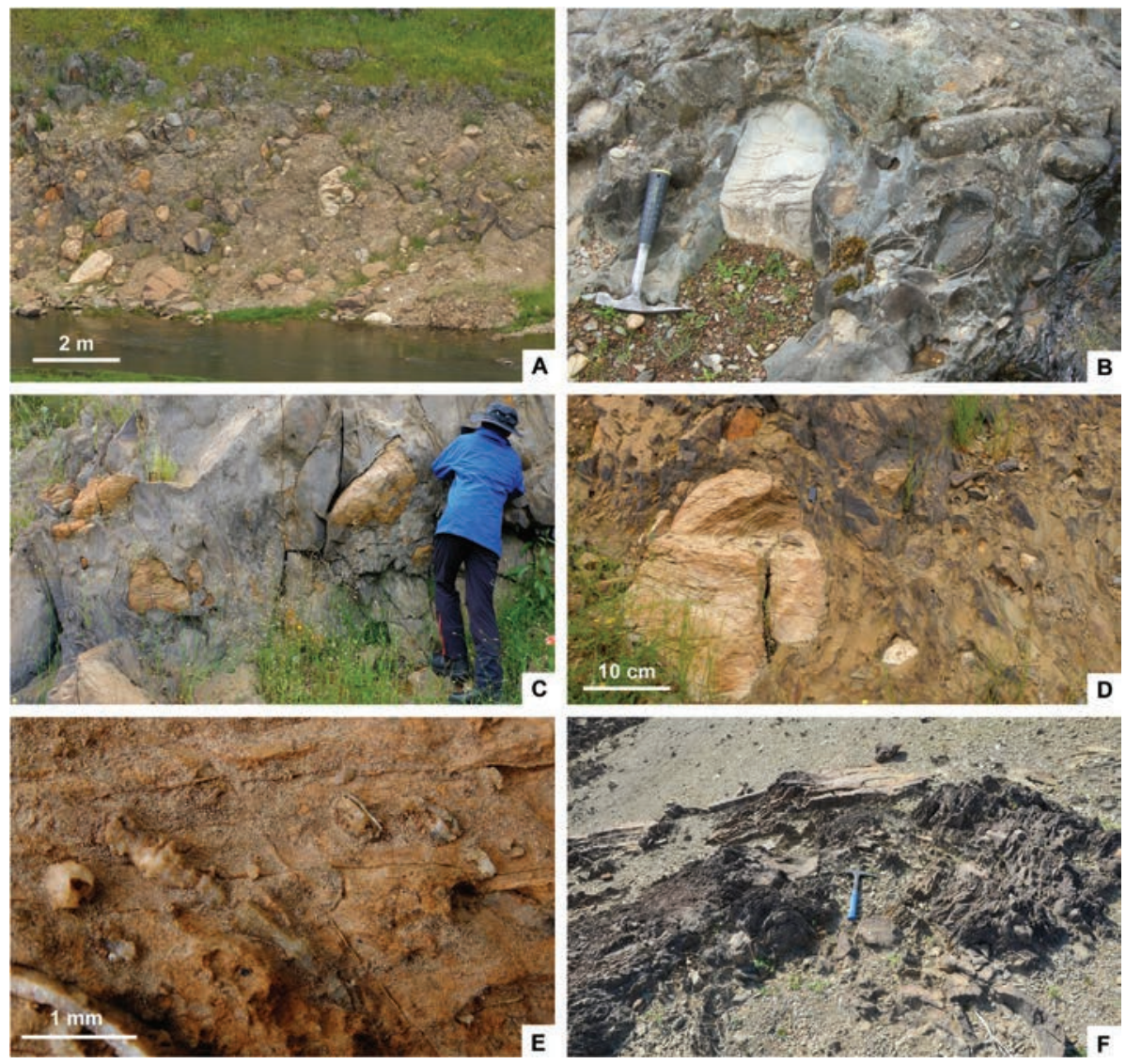

Fig. 11-Field aspect of the megabreccia beds. A. Clast-supported unsorted blocks of limestones (blueish) and dolostones (orangestained) from the Membrillar Bed, at San Marco River. B. Chaotic mixture of angular-to-subrounded limestone blocks of the Fuentes Bed at the Fresnedoso stream. C-D. Dolostone blocks embedded in a muddy matrix from the Membrillar Bed at San Marco River. E. Remains of Cloudina carinata from a carbonate block encased in the Membrillar Bed at the Cubilar stream. F. Disorganized aspect (slumped breccia beds) marking the base of the Pusa Formation at the Estenilla River mouth on the Cíjara dam.

\section{Pusa Formation ("Pusa Shales" of Herranz et al., 1977)}

The Pusa Formation, up to $3500 \mathrm{~m}$ thick, is a heterolithic unit dominated by shale strata but episodically containing breccia, conglomerate and mélange interbeds, sandstone/ shale alternations, local carbonate interbeds and phosphorites. Its stratotype lies along an abandoned railway section, about $4 \mathrm{~km}$ to the west of La Nava de Ricomalillo village (GPS: N39 $39^{\prime} 43^{\prime \prime}, \mathrm{W}^{\circ} 2^{\prime} 2^{\prime \prime}$; see Brasier et al., 1979). A parastratotype lies along the neighbouring Huso River, close to the same village. The formation was subdivided by Gabaldón López \& Hernández Urroz (1989) into six sequence units, but only three are mappable (e.g., Vidal et al., 1994b). These have been traditionally considered as members: a conglomerate-bearing member, with high modifications in phosphate content, sandwiched between two shale-dominant ones.
Until the 1970s, the age of the Pusa Formation was tentatively assigned to the Vendian. Brasier et al. (1979) reported the presence of Beltanelloides ("Vendian") and Chuaria ("upper Riphean-Vendian") associated with ichnofossils, such as Monomorphichnus, which suggested the onset of a superposition of distinct Vendian and Cambrian fossil remains. San José (1983) suggested placing the base of the Cambrian at an indeterminate horizon ranging from the base of the megrabreccias to the top of the Pusa Shales.

5.1. The lower member, about $1100 \mathrm{~m}$ thick, shows abundant slumpings, breccia levels and contorted beds at its basal part (Figs. 11F, 12A). Basal clast- and matrixsupported breccias and contorted beds, rich in abundant hydrothermal veins and clasts, grade upward into monotonous shale (Fig. 12B) with interbedded greywacke sandstone. Phosphatic crusts are locally abundant. The only body fossils known from this member are circular (now 

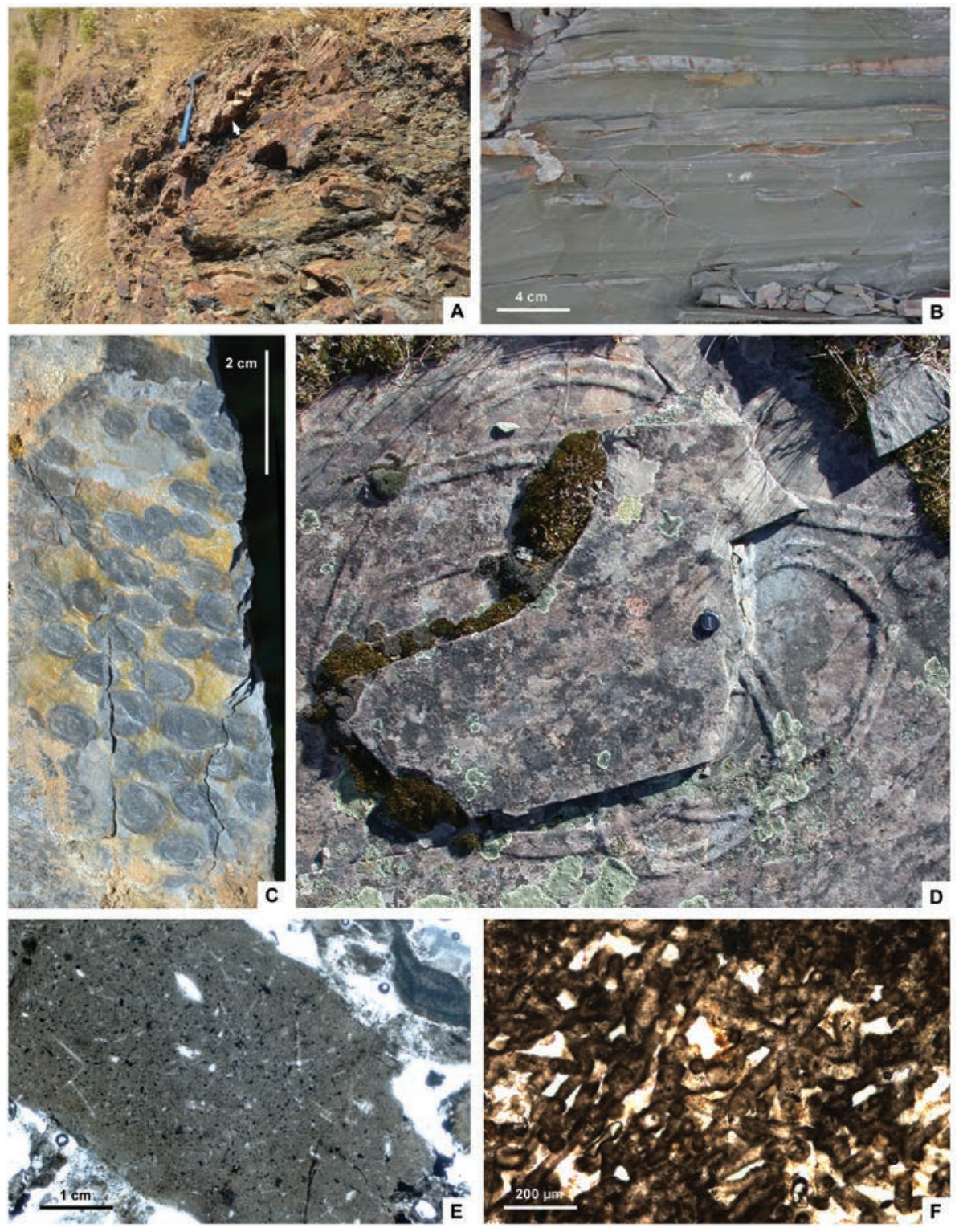

Fig. 12-Field view and thin-section microphotographs of different facies of the Pusa Formation. A. Contorted breccia and bedded deposits ("disorganized facies") containing fragments of hyrothermal dykes (arrowed) marking the base of the Pusa Formation at the Cíjara dam, and representing the base of the Formation in the absence of the aforementioned megabreccia beds. B. Distal tempestites close to the transiton of the middle-to-upper member at La Nava de Ricomalillo. C. Beltanelliformis sp. at an abandoned railway section near Campillo de la Jara. D. Psammichnites gigas from the upper member, Los Alares area. E-F. Thin-sections of phosphate clasts from the Fontanarejo Bed showing preservation of sponge spicules; by courtesy of Joachim Reitner.

tectonically elongated) carbonaceous compressions that have been reported under various names (see above) but are now generally attributed to Beltanelliformis. (e.g., Jensen et al., 2006; Ivantsov et al., 2014) (Fig. 11C). Their stratigraphic implications will be discussed below. Trace fossils include a range of ichnotaxa (e.g. Vidal et al., 1994b; Jensen et al., 2006; Gámez Vintaned \& Liñán, 2007), such as Monomorphichnus lineatus Crimes et al.
(1977), Treptichnus bifurcus Miller, 1889 from the middle part of the member. Liñán et al. (1993) proposed as stratotype section for the base of the Cordub(i)an regional Stage the aforementioned disused railtrack section, close to the La Nava de Ricomalillo. Talavera et al. (2012) reported youngest concordant detrital zircon ages of $536 \pm 13 \mathrm{Ma}$ and $533 \pm 17 \mathrm{Ma}$ from the approximate mid-portion of this unit; additional detrital zircon ages from the lower member 
would help constraining the maximum depositional age of this unit and the formation of the Fuentes Bed.

5.2. The middle member contains conglomerates rich in quartz with subsidiary sandstones, shales rich in disseminated apatite and phosphatic crusts. The member is characterized by a finely developed lamination. In the Navalpino Anticline, the phosphorites can reach $500 \mathrm{~m}$ in thickness, and form an amalgamation of channels rich in lithoclasts, oncoids and phosphatic hardground-derived clasts (Gabaldón López et al., 1987; Santamaría et al., 1987a, b; Santamaría, 1988, 1996; Picart Boira, 1988; Gabaldón López \& Hernández Urroz, 1989; Santamaría i Casanovas, 1995; Álvaro et al., 2016b).

Ore deposits of economic importance are lithostratigraphically represented by the Fontanarejo Bed (Nozal Martín et al., 1988a, b, c; Perconig et al., 1983, 1986; Gabaldón López et al., 1987; Santamaría et al., 1987a; Picart Boira, 1988; Santamaría, 1988, 1996; Gabaldón López \& Hernández Urroz, 1989; López \& Hernández Urroz, 1989) in the Valdelacasa and Navalpino anticlines. Notable occurrences include those at Robledo del Mazo and Horcajo de los Montes in the Valdelacasa Anticline and at Fontanarejo in the Navalpino Anticline (level Ic of Perconig et al., 1983). Channel infill consists of centimetre to decimetre-scale conglomerate layers punctuated by sandstone and shale beds displaying normal grading, convolute bedding, local soft sediment slumping and disrupted bedding. Conglomeratic units are composed of subrounded and moderately sorted, litharenite cobbles and pebbles embedded in an arkosic matrix. Most of the units are clast-supported. Channel infill consists of homogeneous (amorphous to microcrystalline francolite) and polymictic clasts, phosphatized oncoids (locally up to $75 \%$ in volume), with moderately sorted sericite, quartz and dolomite grains, and scattered pyrite, siderite, zircon, tourmaline and rutile (Álvaro et al., 2016b). Sponge sclerites, probably hexactinellids and demosponges (Fig. 12EF), are scattered and commonly embedded in a thromboid texture (Reitner et al., 2012).

5.3. The upper member, $1900-2000 \mathrm{~m}$ thick, is composed of shale and greywacke sandstone with minor quartz-arenite interbeds and rare carbonates. Depositional sedimentary structures are well developed and soft-sediment slumping is common. In comparison to the underlying members of the Pusa Formation, the upper member represents relative shallower deposits, which grade upward into the conformable Azorejo Formation. Body fossils from the upper part of the member occur near Robledo de Buey, where carbonate-cemented siltstone and partly silicified nodules have yielded trilobites (cf. Abadiella bourgini) and microfossils (Cupitheca, Pelagiella and unidentified hyolithids) (Jensen et al., 2010). This level has also yielded poorly preserved archaeocyaths, amongst which A. Zhuravlev (pers. comm. in Liñán et al., 2015: p. 1130) identified Capsulocyathus sp. Ichnofossils were reported by Jensen et al. (2010), such as Dactyloidites, Psammichnites gigas (Fig. 12D), Teichichnus and the lowest recorded occurrence of Rusophycus in the Pusa Formation. Scenella sp. has been reported across the Member 2-3 transition in the area of La Nava de Ricomalillo.

\section{San Lorenzo (Pieren \& García-Hidalgo, 1999) and Fuentepizarra (new) formations}

These units were defined in the Alcudia Anticline and are considered as lateral equivalents of the lower and middle members of the Pusa Formation, respectively. Due to the presence of reddish channelled conglomerates and sandstones in the neighbouring Abenójar and Tirteafuera domes, as well as variegated sandstone/shale alternations capping the Arrocampo Formation in the Ibor and Navalpino anticlines, both formations are proposed as mappable units.

The San Lorenzo Formation, up to $235 \mathrm{~m}$ thick, consists of reddish amalgamated conglomerate and sandstone beds and channels overlain by variegated and partly burrowed, sandstone/shale alternations. Its type area is located in the eastern part of the Alcudia Anticline, in the vicinity of San Loreno de Calatrava town (GPS: N38 27'57', W348'3"). Its top is commonly eroded beneath the Armorican Quartzite but, in the eastern edge of the anticline, the sandstones are conformably overlain by a monotonous succession of shales ("Upper Shaly Formation" sensu Pieren \& García-Hidalgo, 1999), up to $80 \mathrm{~m}$ thick. The stratotype of the Fuentepizarra Formation (corresponding to the informal "Upper Shaly Formation") is located along its homonymous ravine (GPS: N38 $28^{\prime} 6^{\prime}$ ', W3 $3^{\circ} 47^{\prime} 57^{\prime \prime}$ ), close to San Lorenzo de Calatrava town. In the Alcudia Anticline and the Abenójar Dome, the Fuentepizarra Formation contains several distinct phosphorite (wt.\% $\mathrm{P}_{2} \mathrm{O}_{5}>18 \%$ ) and phosphatic carbonate interbeds (Fig. 13C-D), up to $30 \mathrm{~cm}$ thick, which have yielded microfossils after acid etching (Fig. 13E-F), such as helcionellids (Lorenzo Álvarez \& Solé, 1988; Vidal et al., 1995; Pieren \& García-Hidalgo, 1999), identified as Anabarella plana Vostokova (Gubanov in Vidal et al., 1999; Gubanov \& Peel, 2003) (Fig. 13G). Anabarella may be late Nemakit-Daldynian or early Tommotian in age (Vidal et al., 1999).

\section{Major stratigraphic gaps}

Two major gaps are recognized throughout the Ediacaran-Terreneuvian of the Alcudia valley and the Toledo Mountains. 

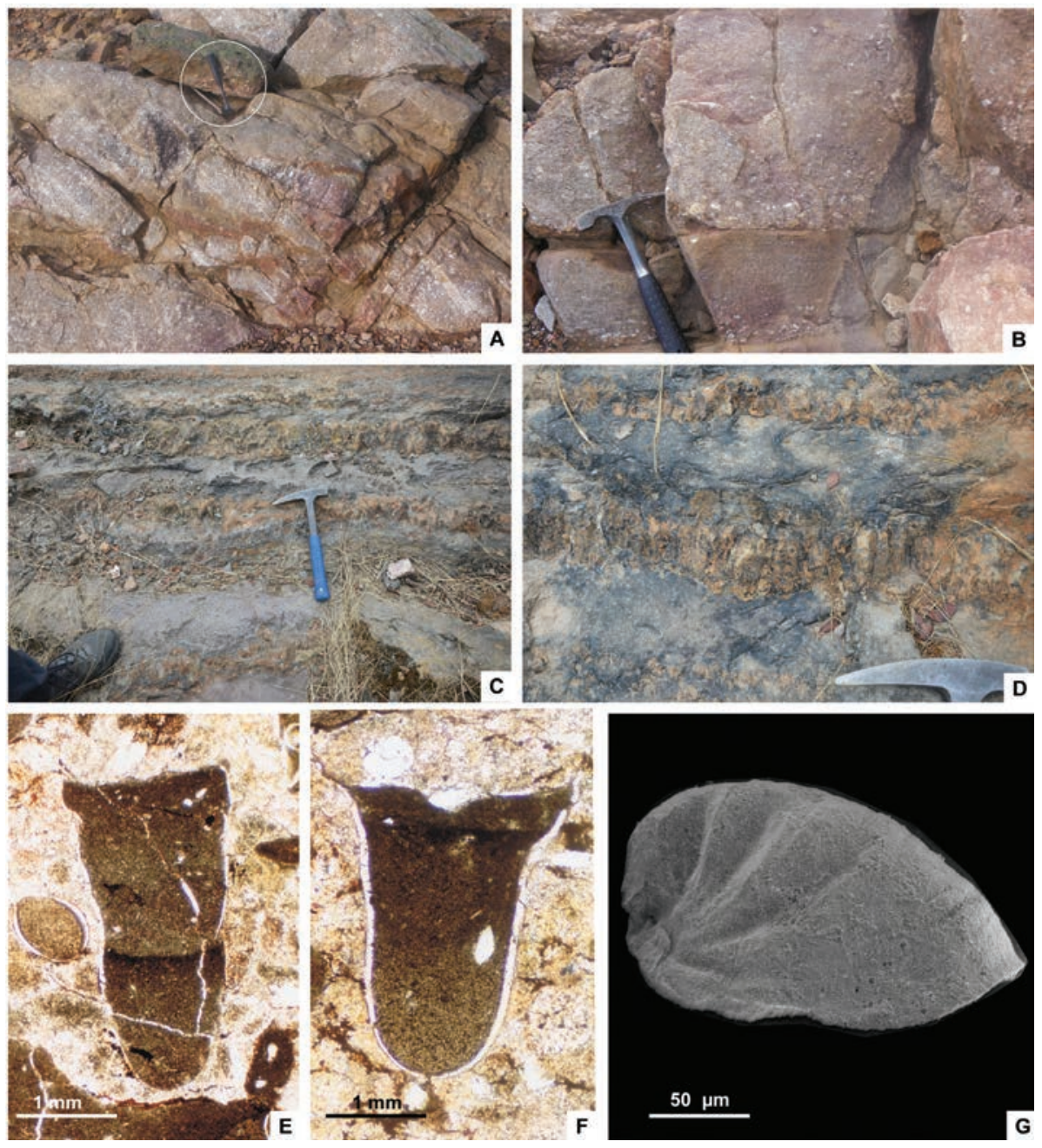

Fig. 13-A-B. Field aspect of the purple conglomerate-to-pebbly sandstones of the San Lorenzo Formation in the vicinity of Los Escoriales. C-D-Alternation of blueish shales and ochre phosphates of the Fuentepizarra Formation, close to San Lorenzo de Calatrava town. E-F. Thin-section photomicrographs of tube-shaped microfossils from the Fuentepizarra phosphatic carbonates. G. Anabarella plana etched from the Fuentepizarra phosphorites.

\section{Late Cadomian gap}

The base of the Ibor Group and the Cíjara Formation represents an intra-late Ediacaran paraconformable to high angular discordance that separates two sedimentary packages with different styles of deformation. The Lower Alcudian-Domo Extremeño Supergroup exhibits steeply plunging cleavage-free folds. The palaeorelief formed as a result of compressive deformation is onlapped by either the Ibor Group or the Cíjara Formation. The deformation phase, named "Oretanian Phase", among others, by San José (1984) and Nozal Martín et al. (1988a, b, c), was firstly recognized in the Alcudia valley (Redlin, 1955; Crespo \& Rey, 1972), although assigned to different ages. At present, it is considered as representative of a "late Cadomian folding event" (Talavera et al., 2015). No metamorphism is associated with this folding event.

Another interpretation for the onset of these steeply plunging folds was proposed by Vidal et al. (1994b), who suggested development of synsedimentary contorsion, and slumping of unconsolidated, kilometre-scale flysch deposits, in a continuous turbiditic-to-basinal infill with lack of shallowing and subaerial exposure. However, this interpretation did not take into account the uplift related to the sedimentation of alluvial-to-fluvial strata onlapping an inherited palaeorelief (e.g., the Orellanita Member of the Castañar Formation in the Sierra de la Zarzuela; Pieren Pidal et al., 1991). In addition, the authors considered the unconformity that marks the top of the Lower 
Alcudian-Domo Extremeño Supergroup as the same than that marking the base of the Pusa Formation, which is described below.

\section{Base of Pusa Formation}

The base of the Pusa Formation is rarely (para)conformable, but represented by the onset of either (i) channelized megabreccias (e.g., Fuentes, Membrillar and Navalpino Beds), infilled with blocks reworked from underlying formations; or (ii) mélange units reworking consolidated and unconsolidated, intraformational shales and sandstones of the basal Pusa Formation. All event beds are affected by common hydrothermal veininig, whose derived counterparts occur as ubiquitous quartz vein clasts.

This intra-Terreneuvian paraconformable to angular discordant contact reflects the episodic record of extensional perturbations of the basement, leading to the erosion and redeposition of detritus derived from underlying formations, such as the Cloudina-bearing carbonate clasts of the Villarta Formation. This contact can be interpreted as the turnover from Cadomianrelated compressive geodynamics (responsible for the input of unsorted siliciclastic clasts and preservation of high-angle substrates) to extensional conditions. In the neighbouring Ossa-Morena Zone, this intra-Terreneuvian episode is represented by the beginning of rifting conditions characterized by massive emplacement of rift-affinity igneous rocks (e.g., Sánchez-García et al., 2019).

\section{Fossil content and chronostratigraphy}

\section{Ediacaran}

Unquestionable Ediacara-type fossils are not known from the Central Iberian Zone although it undoubtedly contains rocks of appropriate age. The absence of such soft-bodied metazoans is likely due to the persistence of high rates of sedimentation of immature sediments in a turbiditic complex, under generally deep-water depths with clayey background sedimentation with little sediment difference for the preservation on bedding-planes. Morphologically simple trace fossils are moderately common in the Cíjara Formation. The lower part of the Ibor Group contains abundant Vendotaenids in the Ibor and Valdemanco anticlines and the Abenójar Dome. Neither the trace fossils nor the Vendotaenids allow a precise chronostratigraphic assignment within the late Ediacaran. Skeletal fossils within carbonates of the Ibor Group, in particular Cloudina, have been considered a solid evidence for a late Ediacaran age. Although this datum remains the most parsimonious interpretation, recent papers suggest the overlap of cloudinids and what is traditionally considered earliest Cambrian small shelly fossils (Yang et al., 2016; Zhu et al., 2017). The survival of Cloudina in Cambrian times cannot be discarded (Linnemann et al., 2019).

\section{Setting of the Ediacaran-Cambrian boundary interval}

In the Valdelacasa Anticle, the presence of carbonaceous Beltanelliformis (in the lower member of the Pusa Formation), a short distance stratigraphically below or slightly overlapping the appearance of distinct Cambriantype trace fossils have been traditionally used to mark the Ediacaran-Cambrian boundary interval (Brasier et al., 1979; Liñán et al., 1984, 1993). This level has remained the favoured placement by some workers (e.g. Gámez Vintated \& Liñán, 1996, 2007). However, this is placed in doubt by the occurrence of both Monomorphichnus and Treptichnus traces from a putatively stratigraphically lower level, within the lower member, in a nearby section (Vidal et al., 1994b; Jensen et al., 2010). Fossils morphologically similar to the Beltanelliforms from the Pusa Formation have been reported from the lower part of the Soltanieh Formation in Iran (e.g. Stöcklin et al., 1964) and occur in the underlying Cíjara Formation. Shahkarami et al. (2017) discussed the stratigraphic implications of the Iranian material and comparable material from South China, and concluded that they are not reliable indicators of pre-Cambrian age.

While the placement of the Ediacaran-Cambrian boundary is somewhat uncertain within the Valdelacasa Anticline, a richer association of fossils with biochronological potential occur in the Ibor Group. Skeletal fossils, in particular Cloudina, within carbonate levels of the Ibor Group, are indicative of a late Ediacaran age. The upper part of the Ibor Group has yielded sabelliditids, including probable Sabellidites cambriensis (Vidal et al., 1994b). Treptichnus pedum occurs at the basal part of the Arrocampo Formation, representing the earliest occurrence of this index-fossil in the Central Iberian Zone.

\section{Terreneuvian}

Terreneuvian skeletal fossils are rare in the Pusa and Fuentepizarra formations. They are only known from a handful of locations where they nevertheless may be abundant. The Fontanarejo Bed (middle member of the Pusa Formation) has yielded sponge spicules embedded 
in thromboid substrates (Fig. 12E-F) (Perconig et al., 1986; Reitner et al., 2012). In the vicinity of La Nava the Ricomalillo, some levels close to the middle-upper member transition have yielded cap-shaped fossils similar to Scenella (Martí Mus et al., 2008) associated with scarce acritarchs (Fig. 14C-F), comprising the only know record of non-bacterial acritarchs from the Pusa Formation in the Valdelacasa Anticline. Remarkable in this context is the occurrence in the Salamanca area of process-bearing acritarchs preserved in carbonate nodules in strata correlatable with the Pusa Formation (Díez Balda \& Furnier Vinas, 1981).

Despite the absence of the helcionellid Watsonella crosbyi, a chronostratigraphically significant biomarker for the future selection of the GSSP marking the Fortunian/ Second Cambrian Stage boundary, the occurrence of the helcionellid Anabarella plana Vostokova (Gubanov in Vidal et al., 1999; Gubanov \& Peel, 2003) in the Fuentepizarra Formation of the Alcudia Anticline allows identification of a biomarker close to the lower occurrence (LO) of $W$. crosbyi. In fact, the stratigraphic range of $A$. plana in the Anabar Uplift of the Siberian Platform (Kouchinsky et al., 2017) allows identification of a time span including the pre-trilobite Purella cristata and Watsonella crosbyi Zones in Siberia.

\section{Inadequate and problematic stratigraphic nomenclature}

Several stratigraphic terms repeatedly used in the literature should not be used due to their ambiguous definition and conceptual modification.
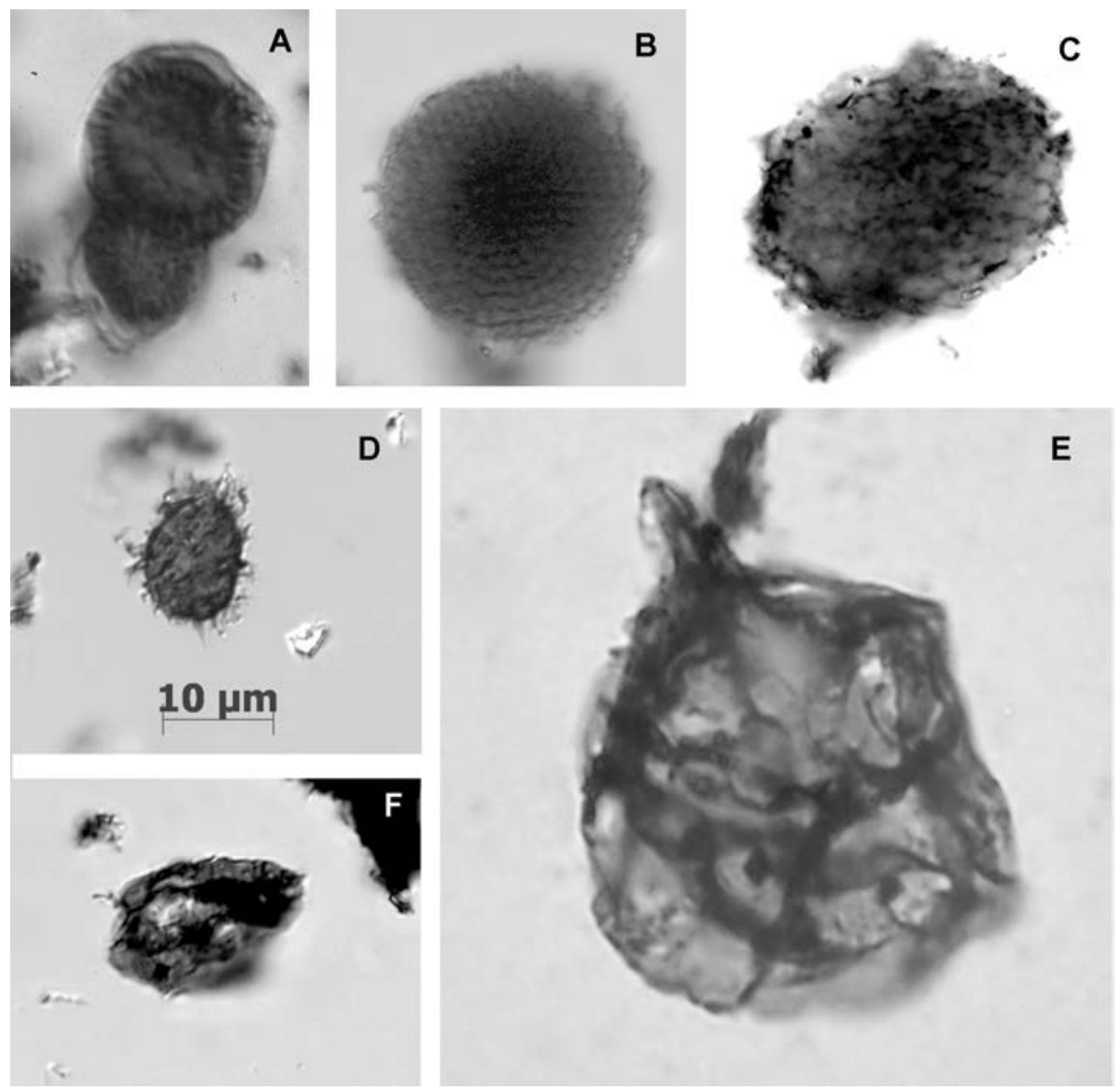

Fig. 14-Selected bacterial (A-C) and acritarch (D-F) remains reported in the text. A. Palaeogomphosphaeria cauriensis, Cíjara Formation, Alagón River section. B. Sphaerocongregus variabilis (Bavlinella faveolata), Castañar Formation, Villarta de los Montes. C. Sphaerocongregus variabilis (Bavlinella faveolata), lower-middle member transition of the Pusa Formation (Scenella level). D. Comasphaeridium sp., Scenella level of the Pusa Formation. E. Alliumella sp., Scenella level of the Pusa Formation. F. Leiosphaeridia sp., Scenella level of the Pusa Formation. 


\section{"Lower Alcudian", "Upper Alcudian" and "Pusian"}

The "Slate and Greywacke Complex" of Carrington da Costa (1950) and Teixeira $(1954,1955)$ was subdivided by Herranz et al. (1977) into three (mixed) litho/chronostratigraphic units, from bottom to top, the $\mathrm{B}[\mathrm{o}]$ eturian (a supposed Grenvillian basement that refers to the Serie Negra, the Ediacaran basement of the neighbouring Ossa-Morena Zone; San José, 1983), the Alcudian and the Pusian. Originally, the Alcudian was considered as a broad monotonous "flysch" lithosome (Bouyx, 1970; Parga, 1970; Vegas, 1971, 1978; Tamain, 1972, 1975; Moreno Serrano, 1974), up to $10 \mathrm{~km}$ thick, which included a heterolithic upper part with conglomerates and limestones. This upper part was considered "molasse" deposits by Maas (1963). Herranz et al. (1977) separated the upper heterolithic part from the lower monotonous "flysch" lithosome naming them "Lower Alcudian" and "Upper Alcudian". Originally, both terms represented mixed litho-chronostratigraphic units (groups and stages) that were separated by a distinct angular discordance. Vilas et al. (1979) and San José (1983) described the "Upper Alcudian", up to $3700 \mathrm{~m}$ thick, as a complex succession of fluvio-tidal deposits influenced by terrigenous and mixed platforms. Due to the presence of microbial structures and imprecise ichnofossils, the "Upper Alcudian" was dated as "Riphean-Vendian" (San José et al., 1974; Brasier et al., 1979).

The term "Pusian" was coined by San José $(1983,1984)$ as another mixed litho-chronostratigraphic lithosome that included the Precambrian-Cambrian boundary, and was sandwiched between the "olistostrome" megabreccias that unconformably overlie the "Upper Alcudian", and the sandstone packages (Azorejo Formation) that traditionally marked the base of the Cambrian due to the presence of characteristic ichnofossils, such as Astropolithon and Psammichnites (Brasier et al., 1979). The Pusian comprised ichnofossils such as Monomorphichnus and Planolites, and soft-bodied impressions such as Beltanelloides and Chuaria.

Subsequently, San José et al. (1990) considered the terms "Lower Alcudian" and "Upper Alcudian-Pusian" as two megasequences displaying the lithostratigraphic significance of a supergroup. These authors still placed the base of the Cambrian in an indeterminate position within the "Pusian".

\section{"Cordub(i)an"}

The Cordubian or Corduban Stage was formally defined by Liñán et al. (1984) to include all strata of the Iberian Peninsula bearing arthropod-like ichnofossils and underlying the earliest trilobite record "in order to separate it from the Ovetian Stage that was defined using trilobite faunas" (p. 824). The authors proposed the Sierra de Córdoba as a type area for the stage and the (H)uso river section of the Central Iberian Zone (Brasier et al., 1979; Palacios Medrano, 1989) as stratotype for its base, marked by the lowest occurrence (LO) of the ichnogenus Monomorphichnus. Other (para)stratotypes were selected by Liñán et al. (1993) at Barrios de Luna (Cantabrian Zone; Crimes et al., 1977) and Concha de Artedo (West Asturian-Leonese Zone; Crimes et al., 1977) sections, where the Ediacaran/Cambrian contact is marked by an angular discordance, and in the La Rinconada section (Central Iberian Zone; Corrales et al., 1974). The authors also suggested the LO of the ichnofossil Astropolichnus hispanicus as the top of the Corduban in the Tamames Sandstone of the Central Iberian Zone, but this is in contradiction with the base of the overlying Ovetian Stage, defined at the LO of dolerolenid trilobites (Sdzuy, 1971; Liñán et al., 1993).

Subsequently, Liñán et al. (1993) and Gámez-Vintaned \& Liñán (1996) summarized and completed a list of ichnofossils characteristic of the Corduban. Gámez-Vintaned \& Liñán (1996) suggested that the LO of Monomorphichnus "nearly coincides" with that of "Phycodes" pedum, as a result of which they proposed the LO of the M. lineatusT. pedum ichnofossil assemblage as the PrecambrianCambrian boundary in Spain and as new base for the Corduban. In their figure 3 , the base of the upper Corduban Substage is marked by the LO of Rusophycus, predating that of Cruziana.

New findings of shelly fossils and acritarchs somewhat completed this sketch. Palacios \& Vidal (1996) and Vidal et al. (1999) reported the presence of Cloudina in the Ibor Group, and of Anabarella, Aldanella, hyolithids (circothecids and orthothecids), aff. Mongolitubulus and chancelloriids in the Pusa and Fuentepizarra formations; bigotinid trilobite and archaeocyathan moulds were also found in these shales, as a result of which, the authors suggested that part of the Pusa Formation would be NemakitDaldynian to mid-Tommotian in age.

Finally, Liñán et al. (2002) subdivided again the Corduban into two substages, the bases of which were selected at the LO of M. lineatus $+T$. pedum and Rusophycus avalonensis, respectively. However the authors dramatically modified the concept of the stage: Liñán et al. (2002) selected the indeterminate bigotinids reported by Palacios \& Vidal (1996) and Vidal et al. (1999) to characterize the upper part of the lower Corduban. This broke into pieces the original concept of the Corduban as a Cambrian stage underlying the LO of trilobites, originally suggested as correlatable 
with the Nemakit-Daldynian and Tommotian stages of Siberia.

In addition, Liñán et al. (2002) established an ichnofossil-based zone to mark the topmost of the Ediacaran: the Torrowangea rosei Zone. A single specimen of the ichnotaxon Torrowangea aff. rosei from the Saviñan Formation of the Paracuellos Formation, Iberian Chains, was illustrated and described by Liñán \& Tejero (1988); however, this specimen was subsequently reconsidered as questionable by Jensen et al. (2007: Table 1) because "the published information does not allow for a critical evaluation". The presence of T. rosei (without "aff.") in the Pusa (Liñán et al., 2002: p. 19-20) and Cíjara (Gámez-Vintaned, 1996: fig. 9) formations of the western Toledo Mountains has not yet been supported with any illustration.

Based on the presence of T. pedum at the basal part of the underlying Arrocampo Formation, the proposal of the base of the Corduban in the Pusa Formation as the regional Ediacaran-Cambrian boundary should be abandoned. The boundary is identified, at least, at the basal part of the Arrocampo Formation, below the major unconformity that marks the base of the Pusa Formation, and below the base of the regional Corduban Stage sensu Liñán et al. (1993) and Liñán et al. (2002).

\section{Ediacaran-Terreneuvian carbonate production, evaporite record and phosphogenesis in West Gondwana}

The Villarta Formation represents a latest Ediacaran episode of semi-continuous carbonate productivity, characterized by shallowing-upward cycles, less than $8 \mathrm{~m}$ thick, grading from offshore clayey substrates to marlstones/ shales with carbonate nodules and, finally, a widespread variation of carbonate substrates that include: (i) shoreface (wave-influenced) substrates, ooidal shoal complexes and Cloudina-microbial and microbial reefal frameworks. In some intra-platform blocks, the Villarta Formation can be subdivided into three members, the middle one displaying progradation of conglomerate-to-litharenite shoal complexes (e.g., the Villarta type area and Castañar de Ibor in the Ibor Anticline, and exposures surrounding Abenójar in the Alcudia Anticline). The base of the overlying Arrocampo Formation, which broadly corresponds to the LO of T. pedum, marks the final drowning of carbonate productivity on palaeohorsts and blocks and the sedimentation of persistent offshore-dominated clayey substrates. Therefore, the LO of pedum is constrained by facies (so environmental) conditions.

Laterally to the Iberian margin of West Gondwana (Fig. 15), a diachronous carbonate production is reported:

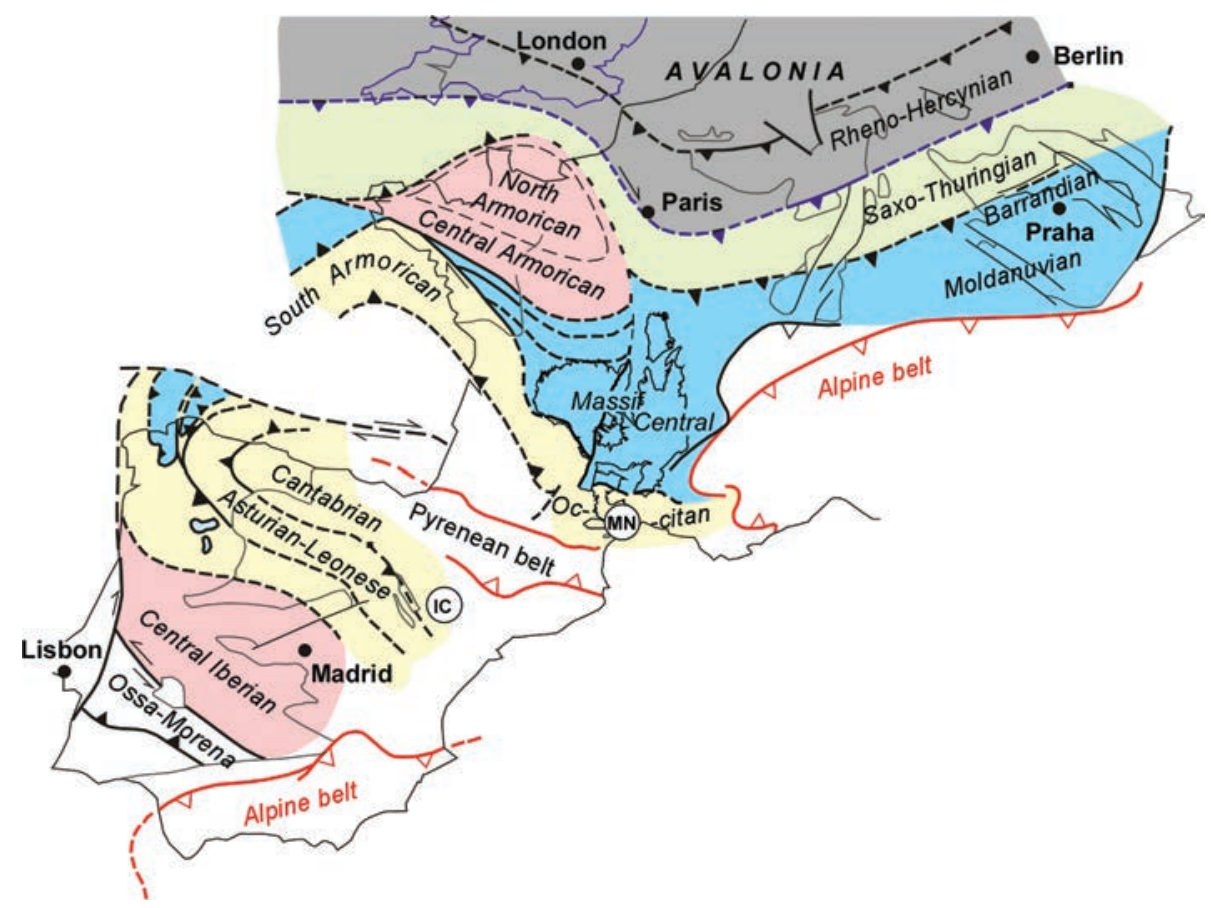

Fig. 15-Pre-Alpine setting of the major Variscan tectonostratigraphic units described in the text; modified from Quesada (1990); ICIberian Chains, MN- Montagne Noire. 
(i) The southwestern prolongation of the Iberian margin has recorded the final episodes of the Pan-African Orogeny. The latter predated in time the SWEuropean Cadomian Orogeny, which represents its lateral continuation. In the Anti-Atlas of Morocco, the end of this orogeny marks the beginning of rifting conditions and the onset of a latest Ediacaran episode of carbonate productivity (phosphatic carbonates of the Taguedit Bed, Tabia Member, Adoudou Formation) followed by a Terreneuvian establishment of intraplatform microbially dominated carbonate production throughout the horst-and-graben framework of the Cambrian Atlas Rift (Tifnout Member, Adoudou Formation; Álvaro et al., 2014a) (Fig. 16).

(ii) To the palaeogeographic north-east of the Iberian margin of Gondwana, the presence of carbonate interbeds across the Ediacaran-Cambrian transition has been reported in: (i) a Fortunian phosphatic limestone bed that punctuates the lower member of the Herrería Formation in the Cantabrian Zone (Álvaro et al., 2016b); (ii) the Fortunian Codos (phosphatic limestone) Bed of the Paracuellos Group (Álvaro et al., 2016b) in the eastern Iberian Chain, which represents the lateral prolongation of the West Asturian-Leonese Zone (Álvaro et al., 2018); (iii) the Terreneuvian phosphatic limestones of the Herault Member (Marcou Formation) in the northern Montagne Noire that onlap the Cadomian Rivernous volcanosedimentary complex (Clausen \& Álvaro, 2007; Devaere et al., 2013; Álvaro et al., 2014b); and (iv) the microbial carbonates of the Puig Sec Member (Pic de la Clape Formation) that onlap the Cadomian Finestrelles volcanosedimentary complex in the Eastern Pyrenees (Padel et al., 2018a, b).

Due to the current co-existence of phosphates and carbonates, phosphogenesis was necessarily associated with carbonate productivity, whereas shallow-water carbonate factories were also related to centres of evaporitic precipitation. Relics of primary and early diagenetic evaporites demonstrate that extensive evaporitic conditions were locally associated with the evolution of the latest Ediacaran-Cambrian Epoch 2 carbonate-dominated and mixed platforms of the western Gondwana margin (Fig. 16). They are preserved as pseudomorphs after evaporites, such as "chicken-wire" and enterolithic structures, lenticular to lozenge-shaped crystals of gypsum and anhydrite relics (Álvaro et al., 2000). According to Scotese \& Barret (1990), among others, the latitudinal abundance of these climatically sensitive facies can be estimated by statistical techniques: carbonates have a maximum likelihood of occurring between $10^{\circ}$ and $30^{\circ}$ latitude, and evaporites at $25^{\circ}$ to $35^{\circ}$ latitude. Therefore, the existence of an Ediacaran-Cambrian Epoch 2 Southern Hemisphere arid belt is envisaged in terms of widespread evaporites in internal platforms.

The occurrence in the late Ediacaran-Cambrian Epoch 2 throughout the Moroccan-SW European margin of West Gondwana of phosphorites (Cook \& Shergold, 1986; Notholt \& Braiser, 1986), reefal and ooidal grainstone carbonates, and evaporites displays a parallel SW-NE-trend migration of evaporitic and phosphoritic belts (Fig. 16). This pattern points to a primary palaeolatitudinal factor controlled by the late EdiacaranCambrian poleward drifting of West Gondwana. The lack of climate-sensitive facies (palaeosols, carbonates, evaporites and phosphorites) in some basins was primarily controlled by orogenic processes (also recorded in a south-west/north-east trend migration), such as the Rokelide (Taoudeni Basin), Pan-African (Morocco) and Cadomian (south-western Europe) orogens. The timetransgressive migration of phosphorites, delayed in time by comparison with subtropical evaporites, should fit with a climatic control (temperate setting) for phosphogenesis (Álvaro et al., 2016b).

\section{Conclusions}

An updated stratigraphic subdivision of the Ediacaran and Terreneuvian from the Alcudia valley and the Toledo Mountains, Central Iberian Zone, is documented. The Lower Alcudian-Domo Extremeño Supergroup is subdivided, from bottom to top, into the conformable Guadiana (La Coronada and Sta. $\mathrm{M}^{\mathrm{a}}$ de Zújar formations) and Campanario (Botija, Monroy and Orellana formations) groups. This sedimentary package is unconformably overlain by either the Ibor Group (Castañar, Villarta and Arrocampo formations) or the Cíjara Formation. The Ediacaran-Cambrian boundary, based on ichnofossils, tentatively lies at the base of the Arrocampo Formation and the uppermost part of the Cíjara Formation. Another unconformity marks the base of the overlying Pusa Formation, which is subdivided into thre members, the middle one characterized by the record of phosphate ore deposits (e.g., the Fontanarejo Bed). In the Alcudia valley, the Ibor Group is subdivided into another threefold, equivalent subdivision, the Tamujar, Hinojosas and Cabezarrubias formations, whereas the equivalent of the lower part of the Pusa Formation is recognized as the San Lorenzo and Fuentepizarra formations.

The terms "Lower Alcudian", "Upper Alcudian" and "Pusian" are inadequate due to the mixture of litho- and chronostratigraphic features and should be ruled out. The boundaries and subdivision of the "Cordub(i)an", 


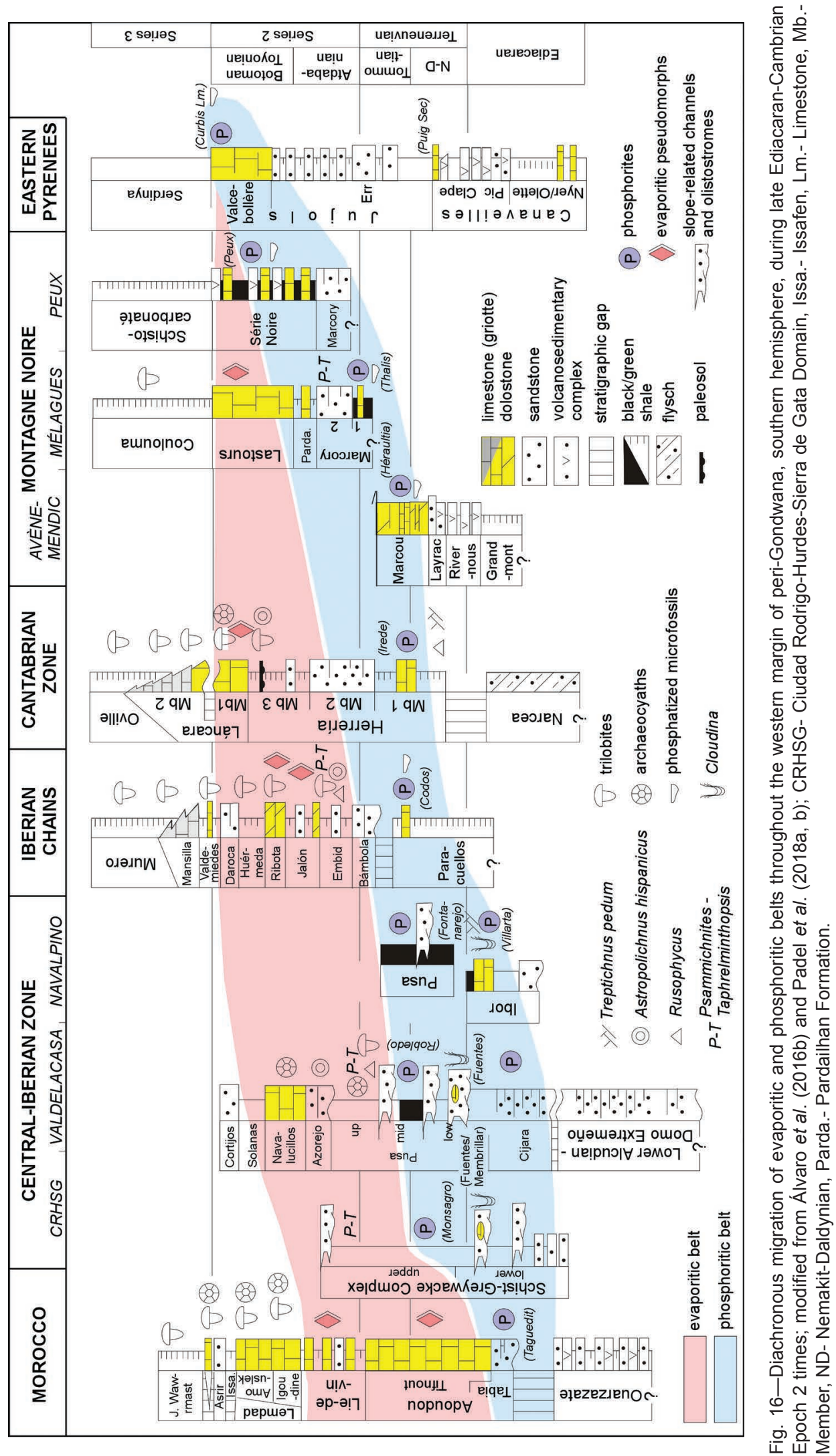


originally proposed as the lowermost and trilobite-free stage of the Cambrian in the Iberian Peninsula, has suffered several modifications that have changed its original meaning. Its base was defined in the Pusa Formation above the erosive unconformity that marks its base. As the first occurrence of Trychophycus pedum is now "lowered" until the basal part of the Arrocampo Formation (Ibor Group), the base of the Cordub(i)an Stage (no matter which one of its successive modifications) does not mark the base of the Cambrian.

Due to the co-occurrence of subtropical facies-sensitive deposists, such as phosphorites, evaporites and carbonate factories leading to reefal and ooidal shoals, a migration of climatically sensitive belts is highlighted following a SW-NE trend, from present-day Morocco to the Iberian Peninsula and the delayed occurrence in southern France, due to the counter-clockwise rotation of Gondwana across the Ediacaran-Cambrian transition. These belts include (i) a proximal evaporitic belt, (ii) a distal phosphogenic belt and (iii) a gradual migration of centres of carbonate production of reefal (microbial and microbial-shelly) ecosystems during late Ediacaran-Cambrian Epoch 2 times.

\section{ACKNOWLEDGEMENTS}

The authors thank the technical support offered by the Villuercas-Ibores-Jara UNESCO Global Geopark for access to its geological sites of interest, thin-section photomicrographs by Joachim Reitner, and useful and constructive revisions by M. Francisco Pereira (Evora) and Cecilio Quesada (Madrid). This updated revision is a contribution to project CGL2017-87631-P from Spanish MINECO.

\section{References}

Ábalos, B. (1990). Cinemática y mecanismos de la deformación en régimen de transpresión. Evolución estructural y metamórfica de la Zona de cizalla dúctil de Badajoz. PhD, Basque Country University, 430 pp.

Ábalos, B.; Gil Ibarguchi, J.I. \& Eguíluz, L. (1991). Cadomian subduction/collision and Variscan transpression in the Badajoz-Córdoba shear belt (southwest Spain). Tectonophysics, 199: 51-72 https://doi. org/10.1016/0040-1951(91)90118-C

Alonso-Zarza, A.M. \& Martín-Pérez, A. (2008). Dolomite in caves: recent dolomiteformation in oxic, non-sulfate environments. Castañar Cave, Spain. Sedimentary Geology, 205: 160-164. https://doi.org/10.1016/j. sedgeo.2008.02.006

Álvarez-Nava, H. \& Robles-Casas, R. (1988). Sobre la existencia de una esquistosidad prehercínica en la zona de Fuenteguinaldo-Pastores, SO de Salamanca (Zona CentroIbérica). II Congreso de Geología de España, Granada, Comunicaciones, 2: 99-102.
Álvarez-Nava Oñate, H.; García Casquero, J.L.; Gil Toja, A.; Hernández Urroz, J.; Lorenzo Álvarez, S.; López Díaz, F.; Mira López, M.; Monteserín López, V.; Nozal Martín, F.; Pardo Alonso, M.V.; Picart Boira, J.; Robles Casas, R.; Santamaría Casanovas, J. \& Solé, F.J. (1988). Unidades litoestratigráficas de los materiales precámbrico-cámbricos en la mitad suroriental de la zona Centro-Ibérica. II Congreso de Geología de España, Granada, Comunicaciones, 1: 19-22.

Álvaro, J.J. \& Vizcaïno, D. (2018). The Furongian break-up (riftdrift) unconformity in the Anti-Atlas, Morocco. Journal of Iberian Geology, 44: 567-587. https://doi.org/10.1007/ s41513-018-0066-2

Álvaro, J.J.; Rouchy, J.M.; Bechstädt, T.; Boucot, A.; Boyer, F.; Debrenne, F.; Moreno-Eiris, E.; Perejón, A. \& Vennin, E. (2000). Evaporitic constraints on the southward drifting of the western Gondwana margin during Early Cambrian times. Palaeogeography, Palaeoclimatology, Palaeoecology, 160: 105-122. https://doi.org/10.1016/ S0031-0182(00)00061-4

Álvaro, J.J.; Monceret, E.; Monceret, S.; Verraes, G. \& Vizcaïno, D. (2010). Stratigraphic record and palaeogeographic context of the Cambrian Epoch 2 subtropical carbonate platforms and their basinal counterparts in SW Europe, West Gondwana. Bulletin of Geosciences, 85: 573-584. https:// doi.org/10.3140/bull.geosci.1179

Álvaro, J.J.; Benziane, F.; Thomas, R.; Walsh, G.J. \& Yazidi, A. (2014a). Neoproterozoic-Cambrian stratigraphic framework of the Anti-Atlas and Ouzellagh promontory (High Atlas), Morocco. Journal of African Earth Sciences, 98: 19-33. https://doi.org/10.1016/j. jafrearsci.2014.04.026

Álvaro, J.J.; Bauluz, B.; Clausen, S.; Devaere, L.; Gil Imaz, A.; Monceret, E. \& Vizcaïno, D. (2014b). Stratigraphic review of the Cambrian-Lower Ordovician volcanosedimentary complexes from the northern Montagne Noire, France. Stratigraphy, 11: 83-96.

Álvaro, J.J.; Colmenar, J.; Monceret, E.; Pouclet, A. \& Vizcaïno, D. (2016a). Late Ordovician (post-Sardic) rifting branches in the North-Gondwanan Montagne Noire and Mouthoumet massifs of southern France. Tectonophysics, 681: 111-123. https://doi.org/10.1016/j.tecto.2015.11.031

Álvaro, J.J.; Shields, G.A.; Ahlberg, P.; Jensen, S. \& Palacios, T. (2016b). Ediacaran-Cambrian phosphorites from the western margins of Gondwana and Baltica. Sedimentology, 63: 350-377. https://doi.org/10.1111/sed.12217

Álvaro, J.J.; Bauluz, B.; Gil Imaz, A. \& Ubide, T. (2018). 40Ar/39Ar chronological constraints on syn- and postVariscan biotite porphyroblasts from the Iberian Chains, NE Spain. Journal of Iberian Geology, 44: 655-670. https://doi. org/10.1007/s41513-018-0065-3

Amaral, A.; Dias, R.; Coke, C.; Romão, J. \& Ribeiro, A. (2014). Fase de deformação sarda na Zona Centro-Ibérica. Comunicações Geológicas, 101: 239-242.

Apalategui, O.; Eguíluz, L.; Martín-Torres, L.M. \& Palacios, T. (2009). Unidades Preordovicicas y megaestructuras Cadomienses en La Serena y La Serena Extremeña (Macizo Ibérico meridional). Geogaceta, 47: 141-144. 
Aramburu, C.; Méndez-Bedia, I.; Arbizu, M. \& García-López, S. (2004). Zona Cantábrica. Estratigrafía. La secuencia preorogénica. In: Geología de España (Vera, J., Ed.). Sociedad Geológica de España \& Instituto Geológico y Minero de España, Madrid, 27-34.

Arenas, R.; Fernández-Suárez, J.; Montero, P. et al. (2018). The Calzadilla ophiolite (SW Iberia) and the Ediacaran fore-arc evolution of the African margin of Gondwana. Gondwana Research, 58: 71-86. https://doi.org/10.1016/j. gr.2018.01.015

Bandrés, A.; Eguíluz, L.; Gil Ibarguchi, J.I. \& Palacios, T. (2002). Geodynamic evolution of a Cadomian arc region: the northern Ossa-Morena zone, Iberian massif. Tectonophysics, 352: 105-120. https://doi.org/10.1016/ S0040-1951(02)00191-9

Bandrés, A.; Eguíluz, L.; Pin, C.; Paquette, J.L.; Ordóñez, B.; Le Fèvre, B.; Ortega, L.A. \& Ibarguchi, J.I. (2004). The northern Ossa-Morena Cadomian batholith (Iberian Massif): magmatic arc origin and early evolution. International Journal of Earth Sciences, 93: 860-885. https://doi. org/10.1007/s00531-004-0423-6

Bernardo de Sousa, M. (1984). Considerações sobre a estratigrafía do Complexo Xisto-Grauváquico $(\mathrm{CXG})$ e sua relação com o Paleozóico inferior. Cuadernos de Geología Ibérica, 9: 9-36.

Bouyx, E. (1961). Au sujet de l'âge des schistes de l'Alcudia. Comptes Rendus Sommaires des Séances de la Société géologique de France, 64-66.

Bouyx, E. (1962). La edad de los esquistos de Alcudia. Notas y Comunicaciones del Instituto Geológico y Minero de España, 66: 197-200.

Bouyx, E. (1970). Contribution à l'étude des formations antéOrdoviciennes de la Meseta méridionale (Ciudad Real et Badajoz). Memorias del Instituto Geológico y Minero de España, 73: 1-263.

Brasier, M.D. \& Cowie, J.W. (1989). Other areas: North-west Canada; California, Nevada, and Mexico; Morocco, Spain, and France. In: The Precambrian-Cambrian Boundary (Cowie, J.W. \& Brasier, M.D., Eds.). Clarendon Press, Oxford, 105-113.

Brasier, M.D.; Perejón, A.; \& de San José, M.A. (1979). Discovery of an important fossiliferous Precambrian-Cambrian sequence in Spain. Estudios Geológicos, 35: 379-383. https://doi.org/10.1016/0031-0182(79)90092-0

Calvet Alonso, F. \& Salas, R. (1988). Tipos de plataformas carbonatadas del Precámbrico terminal de la zona CentroIbérica. II Congreso de Geología de España, Granada, Comunicaciones, 1: 59-62.

Capote, R.; Gutiérrez Elorza, M.; Fernández Casals, M.J.; Moreno, F.; Navidad, M.; Peinado, M. \& Vegas, R. (1977). The Precambrian in the central part of the Iberian massif. Estudios Geológicos, 33: 343-355.

Carrington da Costa, J. (1950). Noticia sobre uma carta geológica do Buçaco, de Nery Delgado. Direcção Geral de Minas e Serviços Geológicos de Portugal, 28 pp.

Castro, A.; Corretgé, G.; de la Rosa, J.; Enrique, P.; Martínez, F.J.; Pascual, E. et al. (2002). Palaeozoic magmatism. In:
The Geology of Spain (Gibbons, W. \& Moreno, T., Eds.). The Geological Society, London, 117-153. https://doi. org/10.1144/GOSPP.8

Clausen, S. \& Álvaro, J.J. (2007). Lower Cambrian shelled phosphorites from the northern Montagne Noire, France. In: Palaeozoic Reefs and Bioaccumulations: Climatic and Evolutionary Controls (Álvaro, J.J.; Aretz, M.; Boulvain, F.; Munnecke, A.; Vachard, D. \& Vennin, E., Eds.). Geological Society, London, Special Publications, 275: 17-28. https://doi.org/10.1144/GSL.SP.2007.275.01.02

Cook, P.J. \& Shergold, J.H. (1986). Proterozoic and Cambrian phosphorites - nature and origin. In: Phosphate Deposits of the World. Vol. 1. Proterozoic and Cambrian Phosphorites (Cook, P.J. \& Shergold, J.H., Eds.). Cambridge University Press, Cambridge, 369-386.

Corrales, I.; Manjón, M. \& Valladares, I. (1974). La serie carbonatada de Navarredonda de la Rinconada (Salamanca, España). Stvdia Geologica, 8: 85-91.

Cortázar, D. de (1878a). Expedición geológica por la provincia de Toledo en 1877. Boletín de la Comisión del Mapa Geológico de España, 5: 139-144.

Cortázar, D. de (1878b). Expedición geológica por la provincia de Toledo en 1878. Boletín de la Comisión del Mapa Geológico de España, 7: 289-330.

Cortijo, I.; Martí Mus, M.; Jensen, S. \& Palacios, T. (2010). A new species of Cloudina from the terminal Ediacaran of Spain. Precambrian Research, 176: 1-10. https://doi. org/10.1016/j.precamres.2009.10.010

Cortijo, I.; Martí Mus, M.; Jensen, S. \& Palacios, T. (2015). Late Ediacaran skeletal body fossil assemblage from the Navalpino anticline, central Spain. Precambrian Research, 267: 186-195. https://doi.org/10.1016/j.precamres.2015.06.013

Crespo, V. \& Rey, J. (1972). Contribución al estudio del valle de Alcudia. Boletín Geológico y Minero, 82: 512-515.

Crespo, V. \& Tamain, F. (1971). Mise en évidence de niveaux carbonatés interstratifiés dans l'Alcudia de la sierra Morena centrale (Espagne). Comptes Rendus de l'Académie des Sciences, Paris, 272: 68-69.

Crimes, T.P.; Legg, I.; Marcos, A. \& Arboleya, M.L. (1977). Late Precambrian-Lower Cambrian trace fossils from Spain. In: Trace Fossils 2 (Crimes, T.P. \& Harper, J.C., Eds.). Geological Journal, Special Issue, 9: 91-138. Seel House Press.

Del Greco, K.; Johnston, S.T. \& Shaw, J. (2016). Tectonic setting of the North Gondwana margin during the Early Ordovician: a comparison of the Ollo de Sapo and Famatina magmatic events. Tectonophysics, 681: 73-84. https://doi. org/10.1016/j.tecto.2016.02.034

Devaere, L.; Clausen, S.; Steiner, M.; Álvaro, J.J. \& Vachard, D. (2013). Chronostratigraphic and palaeogeographic significance of an early Cambrian microfauna from the Heraultia Limestone, northern Montagne Noire, France. Palaeontologia Electronica, 16 (17A): 1-91. https://doi. org/10.26879/366

Dias da Silva, I.; Gómez-Barreiro, J.; Martínez Catalán, M. et al. (2017). Structural and microstructural analysis of the Retortillo Syncline (Variscan belt, Central Iberia). Implications 
for the Central Iberian Orocline. Tectonophysics, 717: 99-115. https://doi.org/10.1016/j.tecto.2017.07.015

Díez Balda, M.A. (1986). El complejo esquisto-grauváquico, las series paleozoicas y la estructura hercínica al Sur de Salamanca. Acta Salmanticensis, Ciencias, 52: 1-162.

Díez Balda, M.A. \& Fournier Vinas, Ch. (1981). Hallazgo de acritarcos en el Complejo Esquisto-Grauváquico al Sur de Salamanca. Acta Geológica Hispánica, 16: 131-134.

Díez Balda, M.A.; Vegas, R. \& González Lodeiro, F. (1990). Part IV. Central Iberian Zone. Structures. In: Pre-Mesozoic Geology of Iberia (Dallmeyer, R.D. \& Martínez García, E., Eds.). Springer-Verlag, Berlin, 172-188.

Díez Fernández, R. \& Pereira, M.F. (2016). Extensional orogenic collapse captured by strike-slip tectonics: Constraints from structural geology and U-Pb geochronology of the Pinhel shear zone (Variscan orogen, Iberian Massif). Tectonophysics, 691: 290-310. https://doi.org/10.1016/j. tecto.2016.10.023

Díez Fernández, R.; Jiménez-Díaz, A.; Arenas, R.; Pereira, M.F. \& Fernández-Suárez, J. (2019). Turning point in the evolving geodynamic setting of Peri-Gondwana. Tectonics, 38: 95-119.

Díez Montes, A.; Martínez Catalán, J.R. \& Bellido Mulas, F. (2010). Role of the Ollo de Sapo massive felsic volcanism of NW Iberia in the Early Ordovician dynamics of northern Gondwana. Gondwana Research, 17: 363-376. https://doi. org/10.1016/j.gr.2009.09.001

Eguíluz, L.; Apraiz, A.; Ábalos, B. \& Martínez-Torres, L.M. (1995). Evolution de la zone d'Ossa Morena (Espagne) au course du Protérozoïque supérieur: Corrélations avec l'orogène cadomien nord armoricain. Géologie de la France, 3: 35-47.

Eguíluz, L.; Ibarguchi, J.L.; Ábalos, B. \& Apraiz, A. (2000). Superposed Hercynian and Cadomian orogenic cycles in the Ossa-Morena zone and related areas of the Iberian Massif. Geological Society of America Bulletin, 112: 1398-1413. https://doi.org/10.1130/0016-7606(2000)112<1398:SHAC $\mathrm{OC}>2.0 . \mathrm{CO} ; 2$

Farias, P.; Gallastegui, G.; González-Lodeiro, F.; Marquínez, J.; Martín Parra, L.M.; Martínez Catalán, J.R.; de Pablo Maciá, J.G. \& Rodríguez Fernández, L.R. (1987). Aportaciones al conocimiento de la litoestratigrafía y estructura de Galicia Central. Memórias da Faculdade de Ciências da Universidade do Porto, 1: 411-431

Fernández, C.; Becchio, R.; Castro, A.; Viramonte, J.M.; MorenoVentas, I. \& Corretgé, L.G. (2008). Massive generation of atypical ferrosilicic magmas along the Gondwana active margin: implications for cold plumes and back-arc magma generation. Gondwana Research, 14: 451-473. https://doi. org/10.1016/j.gr.2008.04.001

Fernández Remolar, D.C.; García-Hidalgo, J.F. \& Moreno-Eiris, E. (2005). Interés del registro de los primeros organismos en el Arcaico y Proterozoico. Boletín de la Real Sociedad Española de Historia Natural (Sección Geológica), 100: 177-209.

Fuenlabrada, J.M.; Pieren, A.P.; Díez Fernández, R.; Sánchez Martínez, S. \& Arenas, R. (2016). Geochemistry of the
Ediacaran-Early Cambrian transition in Central Iberia: tectonic setting and isotopic sources. Tectonophysics, 681: 15-30. https://doi.org/10.1016/j.tecto.2015.11.013

Gabaldón López, V. \& Hernández Urroz, J. (1989). Los fosfatos del Precámbrico-Cámbrico de la Zona Centro-Ibérica, un modelo de yacimiento de origen sedimentario. XII Congreso Español de Sedimentología, Simposios y Conferencias, 283-297.

Gabaldón López, V.; Hernández Urroz, J.; Lorenzo Álvarez, S.; Picart Boira, J.; Santamaría Casanovas, J. \& Solé Pont, F.J. (1987). Sedimentary facies and stratigraphy of Precambrian-Cambrian phosphorites on the Valdelacasa anticline, Central Iberian Zone, Spain. In: Phosphate Deposits of the World. Vol. 2. Proterozoic and Cambrian Phosphorites (Cook, P.J. \& Shergold, J.H., Eds.). Cambridge University Press, Cambridge, 422-428.

Gámez Vintaned, J.A. (1996). The río Huso section. In: Field Trip Guide and Abstracts, II Field Conference of the Cambrian Stage Subdivision Working Groups (Liñán, E.; Gámez Vintaned, J.A. \& Gozalo, R., Eds.). Zaragoza University Press, Zaragoza, 28-31.

Gámez Vintaned, J.A. \& Liñán, E. (1996). Significant ichnological data during the Neoproterozoic-early Cambrian transition in Iberia. In: Field Trip Guide and Abstracts, II Field Conference of the Cambrian Stage Subdivision Working Groups (Liñán, E.; Gámez Vintaned, J.A. \& Gozalo, R., Eds.). Zaragoza University Press, Zaragoza, 101-102.

Gámez Vintaned, J.A. \& Liñán, E. (2007). The PrecambrianCambrian boundary in Spain: ichnofossil palaeobiology and zonation. In: The Rise and Fall of the Vendian (Ediacaran) Biota. Origin of the Modern Biosphere (Semikhatov, M.A., Ed.). Geos, Moscow, 54-57.

García-Arias, M.; Díez-Montes, A.; Villaseca, C. \& BlancoQuintero, I.F. (2018). The Cambro-Ordovician Ollo de Sapo magmatism in the Iberian Massif and its Variscan evolution: A review. Earth-Science Reviews, 1776: 345372. https://doi.org/10.1016/j.earscirev.2017.11.004

García de Figuerola, L.C. (1971). Una estructura interesante: El sinclinal Ordovícico-Silúrico de Sequeros - Ahigal delos Aceiteros. Stvdia Geologica Salmanticensia, 2: 45-56.

García-Guinea, J.; Fernández-Cortes, A.; Álvarez-Gallego, M.; García-Antón, E.; Casas-Ruiz, M.; Blázquez-Pérez, D.; Teijón, O.; Cuezva, S.; Correcher, V. \& Sánchez-Moral, S. (2013). Leaching of uranyl-silica complexes from the host metapelite rock favoring high radon activity of subsoil air: case of Castañar cave (Spain). Journal of Radionalytical and Nuclear Chemistry, 298: 1567-1585. https://doi. org/10.1007/s10967-013-2587-7

García-Hidalgo, J.F. (1984). Los materiales carbonatados del Alcudiense Superior en los alrededores de Casas de Miravete (provincia de Cáceres). Publicaciones Geológicas, 20: 379-389.

García-Hidalgo, J.F. (1985). Estratigrafía y sedimentología del Alcudiense superior en los anticlinorios de Ibor y Navezuelas-Robledollano. Seminarios de Estratigrafía (Serie Monografías), 12: 1-190. 
García-Hidalgo, J.F. (1988). El anticlinal de Ibor: Estratigrafía, sedimentología, tectónica y ciclos sedimentarios. II Congreso de Geología de España, Granada, Comunicaciones, $101-110$.

García-Hidalgo, J.F. (1993a). Las pistas fósiles del Alcudiense Superior en el anticlinal de Ibor. Consideraciones cronoestratigráficas. Geogaceta, 13: 33-35.

García-Hidalgo, J.F. (1993b). Las pistas fósiles de los anticlinales de Alcudia y Abenójar (Zona Centroibérica). Edad de las series. Geogaceta, 13: 57-59.

García-Hidalgo, J.F.; Pieren Pidal, A.P.; Olivé Davó, A.; Carbajal Menéndez, A.; de la Fuente Krauss, J.V.; Moreno, F.; Cantos Robles, R. \& Liñán, E. (1993). Mapa Geológico de España, escala 1:50000. Hoja 779 - Villanueva de La Serena. IGME, Madrid.

Gil Cid, D.; Perejón, A. \& de San José, M.A. (1976). Estratigrafía y paleontología de las calizas cámbricas de Los Navalucillos (Toledo). Tecniterrae, 13: 1-19.

Gubanov, A.P. \& Peel, J.S. (2003). The early Cambrian helcionelloid mollusc Anabarella Vostokova. Palaeontology, 46: 1073-1087. https://doi.org/10.1111/1475-4983.00334

Gutiérrez-Alonso, G.; Fernández-Suárez, J.; Gutiérrez-Marco, J.C.; Corfu, F.; Murphy, J.B. \& Suárez Martínez, S. (2007). $\mathrm{U}-\mathrm{Pb}$ depositional age for the upper Barrios Formation (Armorican Quartzite facies) in the Cantabrian zone of Iberia: implications for stratigraphic correlation and paleogeography. In: The Evolution of the Rheic Ocean: from Avalonian-Cadomian Active Margin to AlleghenianVariscan Collision (Linnemann, R.D.; Nance, P. \& Kraft, G.Z., Eds.). Geological Society of America, Special Paper, 423: 287-296. https://doi.org/10.1130/2007.2423(13)

Gutiérrez-Marco, J.C.; Robardet, M.; Rábano, I.; Sarmiento, G.N.; de San José Lancha, M.A.; Herranz Araújo, P. et al. (2002). Ordovician. In: The Geology of Spain (Gibbons, W. \& Moreno, T., Eds.). Geological Society of London, London, 31-49. https://doi.org/10.1144/GOSPP.4

Hammann, W.; Robardet, M. \& Romano, M. (1982). The Ordovician System in southwestern Europe (France, Spain and Portugal). IUGS Publications, 11: 1-47.

Henriques, S.B.A.; Neiva, A.M.R.; Ribeiro, M.L.; Dunning, G.R. \& Tajčmanová, L. (2015). Evolution of a Neoproterozoic suture in the Iberian massif, Central Portugal: new $\mathrm{U}-\mathrm{Pb}$ ages of igneous and metamorphic events at the contact between the Ossa-Morena Zone and the Central Iberian Zone. Lithos, 220-223: 43-59. https://doi.org/10.1016/j. lithos.2015.02.001

Henriques, S.B.A.; Neiva, A.M.R.; Tajčmanová, L. \& Dunning, G.R. (2017). Cadomian magmatism and metamorphism at the Ossa Morena/Central Iberian zone boundary, Iberian Massif, Central Portugal: geochemistry and P-T constraints of the Sardoal Complex. Lithos, 268-271: 131148. https://doi.org/10.1016/j.lithos.2016.11.002

Herranz, P.; de San José, M.A. \& Vilas, L. (1977). Ensayo de correlación del Precámbrico entre los Montes de Toledo y el Valle del Matachel. Estudios Geológicos, 33: 327-342.

Hufnagel, H. (2008). Kohlige Makroreste aus dem Oberen Proterozoikum der Ibor Antiklinale (Prov. Cáceres, Spanien).
In: La Vida en el Terciario: del impacto del meteorito al origen del hombre. X Jornadas Aragonesas de Paleontología (Arcega Conesa, C. \& Lahoz Gimeno, J., Eds.). Institución Fernando el Católico, Zaragoza, 227-260.

Ivantsov, A.Yu.; Gritsenko, V.P.; Konstantinenko, L.I. \& Zakrevskaya, M.A. (2014). Revision of the Problematic Vendian macrofossil Beltanelliformis (=Beltanelloides, Nemiana). Paleontological Journal, 48 (13), 1423-1448. https://doi.org/10.1134/S0031030114130036

Jensen, S. (2003). The Proterozoic and earliest Cambrian trace fossil record; patterns, problems and perspectives. Integrative and Comparative Biology, 43: 219-228. https://doi. org/10.1093/icb/43.1.219

Jensen, S. \& Palacios, T. (2016). The Ediacaran-Cambrian trace fossil record in the Central Iberian Zone, Iberian peninsula. Comunicaçoes Geológicas, 103: 83-92.

Jensen, S.; Droser, M.L. \& Gehling, J.G. (2006). A critical look at the Ediacaran trace fossil record. In: Neoproterozoic Geobiology and Paleobiology (Xiao, S. \& Kaufman, A.J., Eds.). Springer, Berlin, 115-157. https://doi. org/10.1007/1-4020-5202-2_5

Jensen, S.; Palacios, T. \& Martí Mus, M. (2007). A brief review of the fossil record of the Ediacaran-Cambrian transition in the area of Montes de Toledo-Guadalupe (Spain). In: The Rise and Fall of the Ediacaran Biota (Vickers-Rich, P. \& Komarover, P., Eds). Geological Society, London, Special Publications, 286: 223-235. https://doi.org/10.1144/ SP286.16

Jensen, S.; Palacios, T. \& Martí Mus, M. (2010). Revised biochronology of the Lower Cambrian of the Central Iberian Zone, southern Iberian massif. Geological Magazine, 147: 690-703. https://doi.org/10.1017/S0016756809990677

Julivert, M.; Fontboté, J.M.; Ribeiro, A. \& Conde, L.S. (1972). Mapa tectónico de la Península Ibérica y Baleares, escala 1:1.000.000. IGME, Madrid.

Kouchinsky, A.; Bengtson, S.; Landing, E.; Steiner, M.; Vendrasco, M. \& Ziegler, K. (2017). Terreneuvian stratigraphy and faunas from the Anabar Uplift, Siberia. Acta Palaeontologica Polonica, 62: 311-440. https://doi.org/10.4202/ app.00289.2016

Linnemann, U.; Gerdes, A.; Drost, K. \& Buschmann, B. (2007). The continuum between Cadomian orogenesis and opening of the Rheic Ocean: Constraints from LA-ICP-MS $\mathrm{U}-\mathrm{Pb}$ zircon dating and analysis of plate-tectonic setting (Saxo-Thuringian zone, northeastern Bohemian Massif, Germany). In: The Evolution of the Rheic Ocean: from Avalonian-Cadomian Active Margin to AlleghenianVariscan Collision (Linnemann, U.; Nance, R.D.; Kraft, P. \& Zulauf, G., Eds.). Geological Society of America, Special Paper, 423: 61-96. https://doi.org/10.1130/2007.2423(03)

Linnemann, U.; Pieren, A.; Hofmann, M.; Drost, K.; Quesada, C.; Axel, G.; Marko, L.; Gärtner, A.; Zieger, J. \& Jens, U. (2018). A $\sim 565$ Ma old glaciation in the Ediacaran of peri-Gondwanan West Africa. International Journal of Earth Sciences, 107: 885-911. https://doi.org/10.1007/s00531-017-1520-7

Linnemann, U.; Ovtcharova, M.; Schaltegger, U.; Gärtner, A.; Hautmann, M.; Geyer, G.; Vickers-Rich, P.; Rich, T.; 
Plessen, B.; Hofmann, M.; Zieger, J.; Krause, R.; Kriesfeld, L. \& Smith, J. (2019). New high-resolution age data from the Ediacaran-Cambrian boundary (South Namibia) indicate rapid, ecologically driven onset of the Cambrian explosion. Terra Nova, 31: 49-58. https://doi.org/10.1111/ ter. 12368

Liñán, E. \& Palacios, T. (1982). Asociaciones de pistas fósiles y microorganismos de pared orgánica del Proterozoico en las facies esquisto-grauváquicas del norte de Cáceres. Consecuencias regionales. Boletín de la Real Sociedad Española de Historia Natural (Sección Geológica), 82: 211-232.

Liñán, E. \& Tejero, R. (1988). Las formaciones precámbricas del antiforme de Paracuellos (Cadenas Ibéricas). Boletín de la Real Sociedad Española de Historia Natural (Sección Geológica), 84: 39-49.

Liñán, E.; Palacios, T. \& Perejón, A. (1984). Precambrian-Cambrian boundary and correlation from southwestern and central Spain. Geological Magazine, 121: 221-228. https:// doi.org/10.1017/S0016756800028284

Liñán, E.; Perejón, A. \& Sdzuy, K. (1993). The Lower-Middle Cambrian stages and stratotypes from the Iberian Peninsula: A revision. Geological Magazine, 130: 817-833. https://doi.org/10.1017/S0016756800023189

Liñán, E.; Gozalo, R.; Palacios, T.; Gámez Vinaned, J.A.; Ugidos, J.M. \& Mayoral, E. (2002). Cambrian. In: The Geology of Spain (Gibbons, W. \& Moreno, T., Eds.). Geological Society, London, 17-29. https://doi.org/10.1144/GOSPP.3

Liñán, E.; Gámez Vintaned, J.A. \& Gozalo, R. (2015). The middle lower Cambrian (Ovetian) Lunagraulus n. gen. from Spain and the oldest trilobite records. Geological Magazine, 152: 1123-1136 https://doi.org/10.1017/ S0016756815000084

Llopis, N.; de San José, M.A. \& Herranz, P. (1970). Nota sobre una discordancia posiblemente precámbrica al SE de la provincia de Badajoz, y sobre la edad de las series paleozoicas circundantes. Boletín Geológico y Minero, 81: 586-592.

López, V. \& Hernández Urroz, J. (1989). Los fosfatos del Precámbrico-Cámbrico de la Zona Centro-Ibérica, un modelo de yacimiento de origen sedimentario. XII Congreso Español de Sedimentología, 283-297.

López Díaz, F. (1992). Evolución estructural del antiforme de Navalpino (Zona Centroibérica). PhD, University of Oviedo.

López Díaz, F. (1994). Estratigrafía de los materiales ante-ordovícicos del anticlinal de Navalpino (Zona Centro-Ibérica). Revista de la Sociedad Geológica de España, 7: 31-45.

López-Guijarro, R.; Armendáriz, M.; Quesada, C.; FernándezSuárez, J.; Murphy, J.B.; Pin, Ch. \& Bellido, F. (2008). Ediacaran-Palaeozoic tectonic evolution of the Ossa Morena and Central Iberian zones (SW Iberia) as revealed by $\mathrm{Sm}-\mathrm{Nd}$ isotope systematics. Tectonophysics, 461: 202214. https://doi.org/10.1016/j.tecto.2008.06.006

Lorenzo Álvarez, S. \& Solé, J. (1988). La discordancia intraprecámbrica y la estratigrafía del Precámbrico superior en el sector suroriental del Anticlinal de Abenójar-Tirteafuera. Congreso Geológico de España, 1: 115-118.
Lotze, F. (1945). Einige Probleme der Iberischen Meseta. Geotektonische Forschungen, 6: 1-12.

Lotze, F. (1956). Das Präkambrium Spaniens. Neues Jahrbuch für Geologie und Paläontologie, Monatshefte, 8: 373-380.

Maas, R. (1963). Geologische Beobachtungen in der östlichen Extremadura (Spanien). Neues Jahrbuch für Geologie und Palätontologie, Abhandlungen, 117: 185-207.

Martí Mus, M.; Palacios, T. \& Jensen, S. (2008). Size of the earliest mollusks: did small helcionellids grow to become large adults? Geology, 36: 175-178. https://doi.org/10.1130/ G24218A.1

Martín-García, R.; Alonso-Zarza, A.M. \& Martín-Pérez, A. (2009). Loss of primary texture and geochemical signatures in speleothems due to diagenesis: evidences from Castañar Cave, Spain. Sedimentary Geology, 221: 141-149. https:// doi.org/10.1016/j.sedgeo.2009.09.007

Martín-García, R.; Martín-Pérez, A. \& Alonso-Zarza, A.M. (2011). Weathering of host rock and corrosion over speleothems in Castañar cave, Spain: an example of a complex meteoric environment. Carbonates and Evaporites, 26: 83-94. https://doi.org/10.1007/s13146-010-0039-9

Martín-García, R.; Alonso-Zarza, A.M.; Frisia, S.; RodríguezBerriguete, A.; Drysdalle, R. \& Hellstrom, J. (2019). Effect of aragonite to calcite transformation on the geochemistry and dating accuracy of speleothems. An example from Castañar Cave, Spain. Sedimentary Geology, 383: 41-54. https://doi.org/10.1016/j.sedgeo.2019.01.014

Martín-Pérez, A.; Martín-García, R. \& Alonso-Zarza, A.M. (2012). Diagenesis of a drapery speleothem from Castanar Cave: from dissolution to dolomitization. International Journal of Speleology, 41: 251-266. https://doi. org/10.5038/1827-806X.41.2.11

Martínez Catalán, J.R.; Hacar Rodríguez, M.P.; Villar Alonso, P.; Pérez-Estaún, A. \& González Lodeiro, F. (1992). Lower Palaeozoic extensional tectonics in the limit between the West Asturian-Leonese and the Central Iberian Zones of the Variscan Fold-Belt in NW Spain. Geologische Rundschau, 81: 545-560. https://doi.org/10.1007/BF01828614

Martínez Catalán, J.R.; Martínez Poyatos, D. \& Bea, F. (2004). Zona Centroibérica. Introduction. In: Geología de España (Vera, J., Eds.). Sociedad Geológica de España \& Instituto Geológico y Minero de España, Madrid, 68-69.

Martínez Poyatos, D.J. (2002). Estructura del borde meridional de la Zona Centroibérica y su relación con el contacto entre las zonas Centroibérica y de Ossa Morena. Serie Nova Terra, 18. Ediciós do Castro, A Coruña (PhD Thesis, Granada University, 1997).

McDougall, N.; Brenchley, P.J.; Rebelo, J.A. \& Romano, M. (1987). Fans and fan deltas - precursors to the Armorican Quartzite (Ordovician) in western Iberia. Geological Magazine, 124: 347-359. https://doi.org/10.1017/ S0016756800016678

Medina, J. (1996). Contribuição para o conhecimento da geologia do Grupo das Beiras (CXG) na região do CaramuloBuçaco (Portugal Central). PhD, Universidade de Aveiro.

Medina, J.; Rodríguez Alonso, M.D. \& Alonso Gavilán, G. (1998). Sedimentação em plataforma siliciclástica do 
Grupo das Beiras (CXG) na região de Caramulo - Buçaco (Portugal Central). Comunicaçaos do Instituto Geológico e Mineiro, 85: 39-71.

Meireles, C.; Sequeira, A.J.D.; Castro, P. \& Ferreira, N.I. (2013). New data on the lithostratigraphy of Beiras Group (Schist Greywacke Complex) in the region of Góis-ArganilPampilhosa da Serra (Central Portugal). Cuadernos do Laboratorio Xeolóxico de Laxe, 37: 105-124.

Miller, S.A. (1889). North American Geology and Paleontology for the use of Amateurs, Students, and Scientists, 664Cincinnati, Ohio: Western Methodist Book Concern. https:// doi.org/10.5962/bhl.title. 28778

Mitrofanov, F.P. \& Timofeev, B.V. (1977). Première étude des microfaunes du Précambrien de la Peninsule lbérique. Institute of Precambrian Geology and Geochronology, Leningrad, $2 \mathrm{p}$.

Montero, P.; Talavera, C. \& Bea, F. (2017). Geochemical, isotopic and zircon ( $\mathrm{U}-\mathrm{Pb}, \mathrm{O}, \mathrm{Hf}$ isotopes) evidences for the magmatic sources of the volcano-plutonic Ollo de Sapo Formation, Central Iberia. Geologica Acta 15: 245-260.

Monteserín López, V. \& Pérez Rojas, A. (1987). Mapa Geológico de España, escala 1:50.000. Hoja 652 - Jaraicejo. IGME, Madrid.

Monteserín López, V.; Nozal Martín, F.; López Díaz, J.; Rubio Pascual, F.J. \& Serrano García, A. (1989). Mapa Geológico de España, escala 1:50.000. Hoja 734 -Villarta de los Montes. IGME, Madrid.

Moorman, M. (1974). Microbiota of the late Proterozoic Hector Formation, southwestern Alberta, Canada. Journal of Paleontology, 48: 524-539.

Moreno, F. (1975). Olistostromas, fangoconglomerados y 'slump folds'. Distributión de facies en las series de tránsito Cámbrico-Precámbrico en el anticlinal de Valdelacasa. (Provincias de Toledo, Cáceres y Ciudad Real). Estudios Geológicos 31: 249-260.

Moreno, F. (1977a). Estudio geológico de los Montes de Toledo occidentales. PhD Complutense University, Madrid.

Moreno, F. (1977b). Tectónica y sedimentación de las series de tránsito (Precámbrico terminal) entre el anticlinal de Valdelacasa y el Valle de Alcudia. Ausencia de Cámbrico. Studia Geológica, 12: 123-136.

Moreno, F.; Vegas, R. \& Marcos, A. (1976). Sobre la edad de las series ordovícicas y cámbricas relacionadas con la discordancia "Sárdica" en el anticlinal de Valdelacasa (Montes de Toledo, España). Breviora Geologica Asturica, 20: $8-15$.

Moreno Serrano, F. (1974). Las formaciones anteordovícicas del anticlinal de Valdelacasa. Boletín Geológico y Minero de España, 85: 396-400.

Murphy, E. \& Salvador, A. (1998) International Stratigraphic Guide - An abridged version. Episodes, 22 (4), 255-272.

Murphy, J.B.; Quesada, C.; Gutiérrez-Alonso, G.; Johnston, S.T. \& Weil, A. (2016). Reconciling competing models for the tectono-stratigraphic zonation in western Europe. Tectonophysics, 681: 209-219. https://doi.org/10.1016/j. tecto.2016.01.006
Nance, R.D.; Gutiérrez-Alonso, G.; Keppie, J.D.; Linnemann, U.; Murphy, J.B.; Quesada, C.; Stratchan, R.A. \& Woodcock, N.H. (2010). Evolution of the Rheic Ocean. Gondwana Research, 17: 194-222. https://doi.org/10.1016/j. gr.2009.08.001

Nance, R.D.; Gutiérrez-Alonso, G.; Keppie, J.D.; Linnemann, U.; Murphy, J.B.; Quesada, C.; Stratchan, R.A. \& Woodcock, N.H. (2012). A brief history of the Rheic Ocean. Geoscience Frontiers, 3: 125-135. https://doi.org/10.1016/j. gsf.2011.11.008

Notholt, A.J.G. \& Brasier, M.D. (1986). Proterozoic and Cambrian phosphorites - regional review: Europe. In: Phosphate Deposits of the World. Vol. 1. Proterozoic and Cambrian Phosphorites (Cook, P.J. \& Shergold, J.H., Eds.). Cambridge University Press, Cambridge, 91-100.

Nozal Martín, F. (1985). Mapa Geológico de España a escala 1: 50.000 (2 $2^{\text {a }}$ Serie). Hoja 681 - Castañar de Ibor. IGME, Madrid.

Nozal Martín, E. \& Martín Serrano, A. (1989). Mapa Geológico de España, escala 1:50.000. Hoja 709 - Anchuras. IGME, Madrid.

Nozal, E.; Insúa, M.; de San José, M.A.; López, M.J.; Quintero, I.; Mansilla, N.L.; Rauscher, R. \& Zapardiel, I.M. (1980a). Mapa Geológico de España, escala 1:50.000. Hoja 734 Villarta de los Montes. IGME, Madrid.

Nozal, E.; Insúa, M.; Martín-Serrano, A.; de San José, M.A.; López, M.J.; Quintero, I.; Mansilla, A.I.; Rauscher, R. \& Zapardiel, J.M. (1980b) Mapa Geológico de España, escala 1:50000. Hoja 735 - Fontanarejo. IGME, Madrid.

Nozal Martín, F.; Robles Casas, R. \& Santamaría Casanovas, J. (1988a). Sobre la discordancia intraprecámbrica entre los grupos Domo Extremeño e Ibor en el sector central del Anticlinal de Ibor (Zona Centroibérica). II Congreso de Geología de España, Granada, Comunicaciones, 1: 135-138.

Nozal Martín, F.; Robles Casas, R. \& Santamaría Casanovas, J. (1988b). Series y correlación de los materiales anteordovícicos en los Montes de Toledo y el Sur de Salamanca. II Congreso de Geología de España, Granada, Comunicaciones, 1: 139-142.

Nozal Martín, F. \& Marín Serrano, A. (1989). Mapa geológico de España a escala 1:50.000. Hoja 709 - Anchuras. ITGE, Madrid.

Olivé Davó, A.; Monteserín López, V. \& Andonaegui Moreno, P. (1989a). Mapa Geológico de España a escala 1:50.000 (2 Serie). Hoja 654 - El Puente del Arzobispo. IGME, Madrid.

Olivé Davó, A.; Portero García, J.M.; Álvaro López, M.; Pieren, A.; Aguilar, M.J.; Dabrío, C. \& Nozal, F. (1989b). Mapa Geológico de España a escala 1:50.000. Hoja 756 - Herrera del Duque. ITGE, Madrid.

Ortega, F. \& González Lodeiro, P. (1986). La discordancia intraalcudiense en el dominio meridional de la Zona Centroibérica. Breviora Geologica Asturica, 27: 27-32.

Ortega Gironés, E.; Hernández Urroz, J. \& González Lodeiro, F. (1988). Distribución paleogeográfica y control estructural de los materiales anteordovícicos en la parte suroriental del 
autóctono de la Zona Centro lbérica. II Congreso Geológico de España, Granada, Comunicaciones, 1: 85-89.

Ovtracht, A. \& Tamain, G. (1970). Essai tectonique en Sierra Morena (Espagne). Congrès national des sociétés savantes, Sciences, Reims, C 95 T1: 305-327.

Padel, M.; Clausen, S.; Álvaro, J.J. \& Casas, J.M. (2018a). Review of Ediacaran-Lower Ordovician (pre-Sardic) stratigraphic framework of the Eastern Pyrenees, southwestern Europe. Geologica Acta, 16: 339-355.

Padel, M.; Álvaro, J.J.; Casas, J.M.; Clausen, S.; Poujol, M. \& Sánchez-García, T. (2018b). Cadomian volcanosedimentary complexes across the Ediacaran-Cambrian transition of the eastern Pyrenees, France and Spain. International Journal of Earth Sciences, 107: 1579-1601. https://doi. org/10.1007/s00531-017-1559-5

Palacios, T. (1983). Primeros microfósiles de pared orgánica extraídos en el olistostroma del Membrillar (Proterozoico superior del Centro de España). Revista Española de Micropaleontología, 60: 511-517.

Palacios Medrano, T. (1989). Microfósiles de pared orgánica del Proterozoico superior (región central de la Península Ibérica). Memorias del Museo Paleontológico de la Universidad de Zaragoza, 3: 1-91.

Palacios, T. \& Vidal, G. (1996). Introduction to the late Neoproterozoic-early Cambrian of central Iberia. In: Field Trip Guide and Abstracts, II Field Conference of the Cambrian Stage Subdivision Working Groups (Liñán, E.; Gámez Vintaned, J.A. \& Gozalo, R., Eds.). Zaragoza University Press, Zaragoza, 21-27.

Palacios, T.; Eguíluz, L.; Apalategui, O.; Jensen, S.; López Torres, L.; Carracedo, M.; Gil Ibarguchi, J.I.; Sarrioiandía, F. \& Martí Mus, M. (2010). Mapa Geológico de Extremadura a escala 1:250.000. Memoria, 222 p. Consejería de Industria, Energía y Medio Ambiente, Junta de Extremadura, Mérida.

Palacios, T.; Eguíluz, L.; Apalategui, O.; Jensen, S.; Martínez-Torres, L.; Carracedo, M.; Gil Ibarguchi, J.I.; Sarrioiandía, F. \& Martí Mus, M. (2013). Mapa Geológico de Extremadura a escala 1:350.000. Servicio Editorial de la Universidad del País Vasco (UPV/EHU), Bilbao.

Palero, F.J. (1991). Evolución geotectónica y yacimientos minerales de la región del Valle de Alcudia (sector meridional de la Zona centroibérica). PhD, University of Salamanca.

Palero, F.J. (1993). Tectónica pre-hercínica de las series infraordovícicas del anticlinal de Alcudia y la discordancia intraprecámbrica en su parte oriental (sector meridional de la Zona Centroibérica). Boletín Geológico y Minero, 104: 227-242.

Pardo Alonso, M.V. \& Robles Casar, R. (1988). La discordancia basal del Grupo Valdelacasa en el anticlinal de Valdelacasa. II Congreso de Geología de España, Granada, Comunicaciones, 2: 165-168.

Pardo Alonso, M.V. \& Santamaría Casanovas, J. (1992). El Precámbrico del Anticlinal de Valdelacasa (Montes de Toledo, Zona Centro-Ibérica). Un "puzzle" en vías de resolución.
III Congreso Geológico y VIII Congreso Latinoamericano de Geología, Salamanca, Actas, 1: 175-179.

Parga, J.R. (1970). Evolución del macizo Herpérico en los tiempos ante-mesozoicos y sus relaciones con otras áreas europeas. Boletín Geológico y Minero, 81: 115-143.

Parga, J.R. \& Vegas, R. (1971). Problems and discussion on Precambrian Series of the Hesperic Masif (Western Iberian Peninsula). Geologische Rundschau, 61: 44-68. https:// doi.org/10.1007/BF01836132

Parga, J.R. \& Vegas, R. (1975). El Precámbrico en el cinturón hercínico de la Península Ibérica. Boletín de la Real Sociedad Española de Historia Natural (Sección Geológica), Primer Centenario, 1: 329-345.

Peláez Pruneda, J.R.; García-Hidalgo, J.F.; Moreno-Eiris, E. \& Herranz Araújo, P. (1988). El nivel con carbonatos del "Alcudiense Superior" en el área de CabezarrubiasHinojosas (Valle del Alcudia, Ciudad Real). Geogaceta, 4: 27-28.

Perconig, E.; Vázquez, F.; Velando, F. \& Leyva, F. (1983). Sobre el descubrimiento de fosfatos sedimentarios en el Precámbrico Superior de España. Boletín Geológico y Minero, 114: 187-207.

Perconig, E.; Vázquez, F.; Velando, F. \& Leyva, F. (1986). Proterozoic and Cambrian phosphorites - deposits: Fontanarejo, Spain. In: Phosphate Deposits of the World. Vol. 1. Proterozoic and Cambrian Phosphorites (Cook, P.J. \& Shergold, J.H., Eds.). Cambridge University Press, Cambridge, 220-234.

Pereira, M.F.; Linnemann, U.; Hofmann, M.; Chichorro, M.; Solá, A.R.; Medina, J. \& Silva, J.B. (2012a). The provenance of Late Ediacaran and Early Ordovician siliciclastic rocks in the Southwest Central Iberian Zone: Constraints from detrital zircon data on northern Gondwana margin evolution during the late Neoproterozoic. Precambrian Research, 192-195: 166-189 https://doi.org/10.1016/j. precamres.2011.10.019

Pereira, M. F.; Solá, A.R.; Chichorro, M.; Lopes, L.; Gerdes, A. \& Silva, J.B. (2012b). North-Gondwana assembly, breakup and paleogeography $\mathrm{U}-\mathrm{Pb}$ isotope evidence from detrital and igneous zircons of Ediacaran and Cambrian rocks of SW Iberia. Gondwana Research, 22: 866-881. https:// doi.org/10.1016/j.gr.2012.02.010

Pereira, M.F.; Díez Fernández, R.; Gama, C.; Hofmann, M.; Gärtner, A. \& Linnemann, U. (2018). S-type granite generation and emplacement during a regional switch from extensional to contractional deformation (Central Iberian Zone, Iberian autochthonous domain, Variscan Orogeny). International Journal of Earth Sciences, 107: 251-267. https://doi.org/10.1007/ s00531-017-1488-3

Perejón, A.; Moreno, F. \& Vegas, R. (1976). Datación de las calizas del Cámbrico Inferior de los Navalucillos (Montes de Toledo): Faunas de arqueociatos. Breviora Geologica Asturica, 20: 33-46.

Perejón, A.; Moreno-Eiris, E. \& Herranz Araújo, P. (1981). Datación con arqueociatos del Cámbrico inferior al Norte 
de Llerena, Badajoz (SW de España). Estudios Geológicos, 37: 89-96.

Picart Boira, J. (1988). Facies e interpretación de los yacimientos fosfatados del Cámbrico Inferior de Fontanarejo, Zona Centro Ibérica (Ciudad Real). II Congreso de Geología de España, Granada, Comunicaciones, 2: 157-160.

Pieren Pidal, A.P. (2000). Las sucesiones anteordovícicas de la región oriental de la provincia de Badajoz y área contigua de la de Ciudad Real. PhD, Complutense University, Madrid; eprint: http://eprints.ucm.es/5512/

Pieren Pidal, A.P. (2009). Rasgos geológicos de la comarca de Puertollano y del valle del Alcudia (Ciudad Real, España). Memorias de la Real Sociedad Española de Historia Natural ( $2^{\mathrm{a}}$ serie), 6: 95-132.

Pieren Pidal, A.P. \& Herranz Araújo, P. (1988). Presencia y caracterización del "Alcudiense Superior" (Vendiense) en el entronque de La Serena y el Valle de Alcudia (Este de la Provincia de Badajoz). II Congreso de Geología de España, Granada, Comunicaciones, 1: 91-100.

Pieren, A.P. \& García-Hidalgo, J.F. (1999). El Alcudiense Superior del anticlinal de Alcudia revisitado (Ciudad Real, España central). XV Reunión de Geología del Oeste Peninsular. International Meeting on Cadomian Orogens. Diputación de Badajoz Press, Badajoz, 207-214.

Pieren Pidal, A.P.; Herranz Araújo, P. \& García Gil, S. (1991). Evolución de los depósitos continentales del Proterozoico Superior en 'La Serena', Badajoz (Zona Centro lbérica). Cuadernos do Laboratorio Xeolóxico de Laxe, 16: 179-191.

Piles Mateo, E.; Portero García, J.M.; Álvaro López, M.; Nozal Martín, F, Picart Boira, J. \& Dabrío González, C. (1989). Mapa Geológico de España a escala 1:50.000. Hoja 733 Castilblanco. ITGE, Madrid.

Quesada, C. (1990). Precambrian successions in SW Iberia: their relationship to "Cadomian" orogenic events. In: The Cadomian Orogeny (D’Lemos, R.S.; Trachan, R.A. \& Topley, C.G., Eds.). Geological Society, London, Special Publication, 51: 353-362. https://doi.org/10.1144/GSL. SP.1990.051.01.23

Quesada, C. (1991). Geological constraints on the Paleozoic tectonic evolution of tectonostratigraphic terranes in the Iberian Massif. Tectonophysics, 185: 225-245. https://doi. org/10.1016/0040-1951(91)90446-Y

Quesada, C. (1996). Evolución geodinámica de la zona OssaMorena durante el ciclo Cadomiense. Livro de Homenagem aõ Prof. Francisco Gonçalves, Universidade de Évora, 205-230.

Quesada, C. (2019a). The Cadomian Arc and orogeny in SW Iberia revisited. Geological Association of Canada - Mineralogical Association of Canada, Abstracts Volume, 42: 162.

Quesada, C. (2019b). Cadomian cycle in the Iberian Massif: The arc/back-arc system exposed in the Ossa-Morena Zone. In: The Geology of Iberia: A Geodynamic Approach. Regional Geology Reviews Series, Springer, Heidelberg, vol. 1 (in press).
Quesada, C. \& Dallmeyer, R.D. (1994). Tectonothermal evolution of the Badajoz-Córdoba shear zone (SW Iberia): characteristics and $40 \mathrm{Ar} / 39 \mathrm{Ar}$ mineral age constraints. Tectonophysics, 231: 195-213. https://doi. org/10.1016/0040-1951(94)90130-9

Quesada, C.; Florido, P. Gymiel, P. \& Osborne, J. (1987). Mapa Geológico-Minero de Extremadura. Escala 1:300.000. Junta de Extremadura (Consejería de Industria y Energía), Memoria, $131 \mathrm{p}$.

Ransweiller, M. (1968). Stratigraphie und tektonik der Extremadura im Bereich der orte Herrera del Duque, Helechosa und Villarta de los Montes (Spanien). Dissertationen der Mathematisch-Naturwissenschaftlichen Fakultät der Westfälischen Wilhelms-Universität zu Münster.

Raumer, J.F. von \& Stampfli, F.M. (2008). The birth of the Rheic Ocean - Early Palaeozoic subsidence patterns and subsequent tectonic plate scenarios. Tectonophysics, 461: 9-20. https://doi.org/10.1016/j.tecto.2008.04.012

Redlin, K. (1955). Stratigraphie und Tektonik in der mittleren Sierra Morena im Bereich des Valle de Alcudia (Spanien). Dissertationen der Mathematisch-Naturwissenschaftlichen Fakultät der Westfälischen Wilhelms-Universität zu Münster.

Reitner, J.R.; Luo, C. \& Duda, J.P. (2012). Early sponge remains from the Neoproterozoic-Cambrian phosphate deposits of the Fontanarejo area (central Spain). In: The 17th field conference of the Cambrian Stage Working Group, International Subcommission on Cambrian Stratigraphy and celebration of the 30th anniversary of the discovery of the Kaili Biota. Journal of Guizhou University Natural Sciences, 29: 184-186.

Riaza, C. \& Martínez del Olmo, W. (1996). Depositional model of the Guadalquivir-Gulf of Cadiz Tertiary basin. In: Tertiary Basins of Spain. The Stratigraphic Record of Crustal Kinematics (Friend, P.F. \& Dabrio, C.J., Eds.). World and Regional Geology, 6: 330-338. Cambridge University Press, Cambridge. https://doi.org/10.1017/ CBO9780511524851.047

Ribeiro, A.; Pereira, E. \& Dias, R. (1990). Allochthonous Sequences. Structure in the Northwest of the Iberian Peninsula. In: Pre-Mesozoic Geology of Iberia (Dallmeyer, R.D. \& Martínez García, E., Eds.). Springer, Berlin, 220-236. https://doi.org/10.1007/978-3-642-83980-1_15

Robles, R. \& Álvarez-Nava, H. (1988). Los materiales Precámbrico-Cámbricos del Domo de las Hurdes: Existencia de tres series sedimentarias separadas por discordancias, SO de Salamanca (Zona Centro-Ibérica). II Congreso de Geología de España, Granada, Comunicaciones, 1: 185-188.

Rodríguez Alonso, M.D. (1979). El complejo esquisto-grauváquico y los materiales ordovícicos al $\mathrm{SE}$ de Ciudad Rodrigo (Salamanca - España). Stvdia Geologica Salmanticensia, 14: 7-34.

Rodríguez Alonso, M.D. (1984). El complejo esquisto-grauváquico en el área de Las Hurdes y Sierra de Gata, provincias de Salamanca y Cáceres, España. Cuadernos de Geología Ibérica, 9: 37-80. 
Rodríguez Alonso, M.D. (1985). El Complejo EsquistoGrauváquico y el Paleozoico en el Centro-Oeste español. Acta Salmanticensia, Sección Ciencias, Salamanca, 51: 1-174.

Rodríguez Alonso, M.D.; Alonso Gavilán, G.; Liñán, E.; Gámez-Vintaned, J.A. \& Pérez García, P.P. (1995). Transversal Salamanca-Tamames-Peña de Francia-MonsagroS Ciudad Rodrigo (Spain). Neoproterozoic-Cambrian transition (Aldeatejada Fm, Tamames Sandstone Fm. and the Schist Greywacke Complex in Monsagro- SO of Ciudad Rodrigo). In: XIII Geological Meeting of the West of the Iberian Peninsula. Post-Conference Field Guide. Neoproterozoic-Lower Cambrian in the Central-Western part of the Iberian Peninsula, Spain-Portugal (Rodríguez Alonso, M.D. \& Alonso Gavilán, G., Eds.). 13-66.

Rodríguez Alonso, M.D.; Peinado, M.; López-Plaza, M.; Franco, P.; Carnicero, A. \& Gonzalo, J.C. (2004). NeoproterozoicCambrian synsedimentary magmatism in the Central Iberian Zone (Spain): geology, petrology and geodynamic significance. International Journal of Earth Sciences, 93: 897-920. https://doi.org/10.1007/s00531-004-0425-4

Roiz, J.M. (1979). La estructura y la sedimentación herciniana, en especial el Precámbrico superior, en la región de Ciudad Real-Puertollano. PhD, Complutense University, Madrid.

Roiz, J.M. \& Vegas, R. (1980). Formaciones ordovícicas y anteordovícicas del Anticlinal del Tirteafuera (Sur de la provincia de Ciudad Real). Stvdia Geologica Salmanticensia, $16,27-36$.

Rojo-Pérez, E.; Arenas Martín, R.; Fuenlabrada Pérez, J.M.; Sánchez Martínez, S.; Martín Parra, L.M.; Matas, J.; Pieren Pidal, A.P. \& Díez Fernández, R. (2019). Contrasting isotopic sources $(\mathrm{Sm}-\mathrm{Nd})$ of Late Ediacaran series in the Iberian Massif: Implications for the Central Iberian-Ossa Morena boundary. Precambrian Research, 324: 194-207. https://doi.org/10.1016/j.precamres.2019.01.021

Rölz, P. (1975). Beiträge zur Aufbau des jungpräkambrischen und alpaläozoischen Grundgebirges in den Provinzen Salamanca und Cáceres (Sierra de Tamames, Sierra de Francia und östliche Sierra de Gata, Spanien). Münstersche Forschungen zur Geologie und Paläontologie, 36: 1-68.

Romão, J. \& Ribeiro, A. (1993). Thrust tectonics of Sardic age in the Rosmaninhal area (Beira Baixa, Central Portugal). Comunicações dos Serviços Geológicos de Portugal, 78 (2): 87-95.

Romão, J.; Coke, C.; Dias, R. \& Ribeiro, A. (2005). Transient inversion during the opening stage of the Wilson cycle "sardic phase" in the Iberian variscides - stratigraphic and tectonic record. Geodinamica Acta, 18: 115-129. https:// doi.org/10.3166/ga.18.115-129

Romão, J.; Metodiev, D.; Dias, R. \& Ribeiro, A. (2013). Evolução geodinâmica dos sectores meridionais da Zona Centro-Ibérica. In: Geologia de Portugal, 1 (Dias, R.; Araújo, A.; Terrinha, P. \& Kullberg, J.C., Eds.). Escolar Editora, Lisbon, 206-257.

Russo, A. \& Bechstädt, T. (1994). Evolución sedimentológica y paleogeográfica de la formación Vegadeo (Cámbrico Inferior-Medio) en la zona entre Visuña y Piedrahita do
Laurel (Lugo, NO de España). Revista de la Sociedad Geológica de España, 7: 299-310.

Salvador, A. (1994). International Stratigraphic Guide: A Guide to Stratigraphic Classification, Terminology and Procedure, 2nd edition. International Union of Geological Sciences and Geological Society of America, Trondheim, Norway, 214 pp.

San José, M.A. de (1983). El complejo sedimentario pelíticograuváquico. In: Libro Jubilar J. M. Ríos (Comba, J.A., Ed.). Instituto Geólogico y Minero de España, Madrid, 91-100.

San José, M.A. de (1984). Los materiales anteordovícicos del anticlinal de Navalpino. Cuadernos de Geología Ibérica, 9: 81-117.

San José, M.A. de, Peláez, J.R.; Vilas Minondo, L. \& Herranz, R.P. (1974). Las series ordovícicas y preordovícicas del sector central de los Montes de Toledo. Boletín Geológico y Minero, 85: 21-31.

San José, M.A. de, Pieren Pidal, A.P.; García-Hidalgo, J.F.; Vilas Minondo, L.; Herranz Araújo, P.; Peláez Pruneda, J.R. \& Perejón, A. (1990). Ante-Ordovician stratigraphy. In: PreMesozoic Geology of Iberia (Dallmeyer, R.D. \& Martínez García, E., Eds.). Springer, Berlin, 147-159.

San José, M.A. de, Rábano, I.; Herranz, P. \& Gutiérrez Marco, J.C. (1992). El Paleozoico inferior de la zona Centro Ibérica meridional. In: Paleozoico Inferior de IberoAmérica (Gutiérrez Marco, J.C.; Saavedra, J. \& Rábano, I., Eds.). Extremadura University Press, Mérida, 503-521.

San José, M.A.; Herranz, P. \& Pieren, A.P. (2004). A review of the Ossa-Morena Zone and its limits. Implications for the definition of the Lusitan-Marianic Zone. Journal of Iberian Geology, 30: 7-22.

Sánchez-García, T.; Quesada, C.; Bellido, F.; Dunning, G.R.; Pin, C.; Moreno-Eiris, E. \& Perejón, A. (2016). Age and characteristics of the Loma del Aire unit (SW Iberia): implications for the regional correlation of the OssaMorena Zone. Tectonophysics, 681: 58-72. https://doi. org/10.1016/j.tecto.2016.02.043

Sánchez García, T.; Chichorro, M.; Solá, R.; Quesada, C.; Álvaro, J.J.; Díez Montes, A.; Bellido, F.; Ribeiro, M.L.; Quesada, C.; Lopez, J.L.; Dias da Silva, I.; GonzálezClavijo, E.; Gómez Barreiro, J.L. \& López-Carmona, A. (2019). The Cambrian-Early Ordovician Rift Stage in the Gondwanan Units of the Iberian Massif. In: The Geology of Iberia: A Geodynamic Approach, vol. 2, 27-74 (Quesada, C. \& Oliveira, J.T., Eds.). Regional Geology, Review Series. Springer, Heidelberg (in press).

Santamaría, J. (1988). Facies y asociaciones de facies de las fosforitas de Robledo del Mazo (Precámbrico-Cámbrico de los Montes de Toledo). II Congreso de Geología de España, Granada, Comunicaciones, 1: 205-208.

Santamaría i Casanovas, J. (1995). Los yacimientos de fosfato sedimentario en el límite Precámbrico-Cámbrico del anticlinal de Valdelacasa (Zona Centro-Ibérica). PhD, Autonoma University, Barcelona.

Santamaría, J. (1996). Origen de los elementos fosfatados en los materiales precámbrico-cámbricos de la Zona 
Centro-Ibérica (España). In: Early Paleozoic Evolution in NW Gondwana (Baldis, B. \& Aceñolaza, F.G., Eds.). Serie Correlación Geológica (INSUGEO, Buenos Aires), 12: $310-312$.

Santamaría Casanovas, J. \& Pardo Alonso, M. (1994). Las megabrechas del Membrillar y su relación con el sustrato Precámbrico-Cámbrico de la zona Centro-Ibérica. Geogaceta, 15: 10-13.

Santamaría Casanovas, J. \& Remacha Grau, E. (1994). Variaciones laterales del "Nivel de Fuentes", Precámbrico-Cámbrico de la Zona Centro-Ibérica. Geogaceta, 15: 14-16.

Santamaría, J.; Picart, J. \& Solé, F.J. (1987a). Association of facies of the Pre-Cambrian phosphorites of Horcajo de los Montes (Ciudad Real), Spain. Abstracts VIII European Regional Meeting, IAS, Tunis.

Santamaría, J.; Picart, J. \& Solé, F.J. (1987b). Some sedimentological aspects of the Precambrian phosphorites of Horcajo de los Montes (Ciudad Real), Spain). Abstracts VIII European Regional Meeting, IAS, Tunis.

Scotese, C.R. \& Barret, S.F. (1990). Gondwana's movement over the South Pole during the Palaeozoic: evidence from lithological indicators of climate. In: Palaeozoic Palaeogeography and Biogeography (McKerrow, W.S. \& Scotese C.R., Eds.). Geological Society, Memoirs, 12: 75-85. https://doi.org/10.1144/GSL.MEM.1990.012.01.06

Sdzuy, K. (1971). Acerca de la correlación del Cámbrico inferior en la Península Ibérica. I Congreso Hispano-Luso-Americano de Geología Económica, Geología, 2: 753-766.

Serrano Oñate, A.; Suárez Alba, J.; Martínez del Olmo, W.; Leret Verdú, G. \& García Mallo, J. (1984). Modelo tectosedimentario del Bajo Guadalquivir. I Congreso Español de Geología (Segovia), 1: 199-213.

Shahkarami, S.; Mángano, M.G. \& Buatois, L.A. (2017). Ichnostratigraphy of the Ediacaran-Cambrian boundary: New insights on lower Cambrian biozonations from the Soltanieh Formation of northern Iran. Journal of Paleontology, 91: 1178-1198. https://doi.org/10.1017/jpa.2017.72

Shaw, J.; Johnston, S.T. \& Gutiérrez-Alonso, G. (2012). Oroclines of the Variscan orogen of Iberia: Paleocurrent analysis and paleogeographic implications. Earth and Planetary Science Letters, 329-330: 60-70. https://doi.org/10.1016/j. eps1.2012.02.014

Shaw, J.; Gutiérrez-Alonso, S.; Johnston, S.T. \& Pastor Galán, D. (2014). Provenance variability along the Early Ordovician north Gondwana margin: Paleogeographic and tectonic implications of $\mathrm{U}-\mathrm{Pb}$ detrital zircon ages from the Armorican Quartzite off the Iberian Variscan belt. Geological Society of America Bulletin, doi: 10.1130/B30935.1. https://doi.org/10.1130/B30935.1

Shepeleva, E.D. (1962). Plant? fossils of unknown taxonomic position from the deposits of the Bavlinskaya Series in the Volga Urals oil province. Doklady Akademii nauk Earth Science Transactions (1964), 142: 170-171. Washington.

Simón, J. (2017). Trace fossils and dubiofossils from the Ediacaran and Cambrian of the Alcudia Anticline, Spain. Estudios Geológicos, 73 (2): e068. http://doi.org/10.3989/ egeol.42724.442.
Simón, J. (2018). A transitional Ediacaran-Cambrian biota in the Abenójar anticline (Iberian Massif, Spain). Estudios Geológicos, 74 (2): e084. 18 p. https://doi.org/10.3989/ egeol.43012.470

Stöcklin, J.; Ruttner, A. \& Nabavi, M. (1964). New data on the Lower Paleozoic and Pre-Cambrian of North Iran. Geological Survey of Iran Report, 1: 1-29.

Strauss, H. (2002). The isotopic composition of Precambrian sulphides - seawater chemistry and biological evolution. In: Precambrian Sedimentary Environments: A Modern Approach to Ancient Depositional Systems (Altermann, W. \& Corcoran, P.L., Eds.). Special Publication of the International Association of Sedimentologists, 33: 67-105. https://doi.org/10.1002/9781444304312.ch4

Talavera, C.; Montero, P.; Martínez Poyatos, D. \& Williams, I.S. (2012). Ediacaran to Lower Ordovician age for rocks ascribed to the Schist-Graywacke Complex (Iberian Massif, Spain): Evidence from detrital zircon SHRIMP U-Pb geochronology. Gondwana Research, 22: 928-942. https:// doi.org/10.1016/j.gr.2012.03.008

Talavera, C.; Martínez Poyatos, D. \& González Lodeiro, F. (2015). SHRIMP U-Pb geochronological constraints on the timing of the intra-Alcudian (Cadomian) angular unconformity in the Central Iberian Zone (Iberian massif, Spain). International Journal of Earth Sciences, 104: 1739-1757. https://doi.org/10.1007/s00531-015-1171-5

Tamain, G. (1972). Recherches géologiques et minières en Sierra Morena orientale (Espagne). PhD, University of Paris-Sud.

Tamain, G. (1975). El Alcudiense y la Orogénesis Cadomiense en el Sur de la Meseta Ibérica (España). Boletín de la Real Sociedad Española de Historia Natural (Sección Geológica), Primer Centenario, 437-464.

Teixeira, C. (1954). Os conglomerados do Complexo sixto-grauváquico ante-Silúrico. Sua importancia geológica e paleogeográfica. Communicaçoes dos Serviços Geológicos de Portugal, 1-50.

Teixeira, C. (1955). Notas sobre la geología de Portugal. O complexo xisto-grauváquico ante-ordoviciano. Emprenta Lit. Fluminense, Lisboa, 50 p.

Valladares, M.I.; Barba, P.; Ugidos, J.M.; Colmenero, J.R. \& Armenteros, I. (2000). Upper Neoproterozoic-Lower Cambrian sedimentary successions in the Central Iberian Zone (Spain): sequence stratigraphy, petrology and chemostratigraphy. Implications for other European zones. International Journal of Earth Sciences, 89: 2-20. https:// doi.org/10.1007/s005310050314

Valladares, M.I.; Barba, P. \& Ugidos, J.M. (2002). Precambrian. In: The Geology of Spain (Gibbons, W. \& Moreno, T., Eds.). Geological Society Publications, Bath, 7-16. https:// doi.org/10.1144/GOSPP.2

Vegas, R. (1971). Precisiones sobre el Cámbrico del Centro y S. de España. El problema de la existencia de Cámbrico en el valle del Alcudia y en las sierras de Cáceres y N. de Badajoz. Estudios Geológicos, 27: 414-425.

Vegas, R. (1978). Sedimentation and tectonism in the Iberian Massif prior to the Hercynian deformation (Late 
Precambrian to Silurian times). Cuadernos del Seminario de Estudios Cerámicos de Sargadelos, 27: 271-286.

Vegas, R.; Roiz, J.M. \& Moreno, F. (1977). Significado del complejo esquistoso-grauváquico en relación con las series "pre-Arenig" de España central. Stvdia Geologica Salmanticensia, 12: 207-215.

Vidal, G. 1976. Late Precambrian microfossils from the Visingsö Beds insouthern Sweden. Fossils and Strata, 9: 1-57.

Vidal, G.; Jensen, S. \& Palacios, T. (1994a). Neoproterozoic (Vendian) ichnofossils from lower Alcudian strata in central Spain. Geological Magazine, 131: 169-179. https:// doi.org/10.1017/S0016756800010700

Vidal, G.; Palacios, T.; Gámez-Vintaned, J.A.; Díaz Balda, M.A. \& Grant, S.W.F. (1994b). Neoproterozoic-early Cambrian geology and palaeontology of Iberia. Geological Magazine, 131: 729-765. https://doi.org/10.1017/ S001675680001284X

Vidal, G.; Palacios, T.; Moczydłoska, M. \& Lorenzo Álvarez, S. (1995). A new find of "Tommotian" small shelly fossils from southern Spain. XIII Reunión de Geología del Oeste Peninsular, PIGG 319-320-376, Abstracts, 166-167.

Vidal, G.; Palacios, T.; Moczydłoska, M. \& Gubanov, A.P. (1999). Age constraints from small shelly fossils on the early Cambrian terminal Cadomian Phase in Iberia. GFF, 121: 137143. https://doi.org/10.1080/11035899901212137

Vilas, G.; Peláez, J.R. \& Arche, A. (1979). El Precámbrico del Anticlinorio de Ibor (I). Zona de la Calera, Cáceres. Boletín de la Real Sociedad Española de Historia Natural (Sección Geológica), 77: 141-152.
Vilas, L. \& de San José, M.A. (1990). Part IV. Central Iberian Zone. Autochthonous Sequences. Introduction. In: PreMesozoic Geology of Iberia (Dallmeyer, R.D. \& Martínez García, E., Eds.). Springer-Verlag, Berlin, 145-146.

Vilas, L.; García Hidalgo, J.F.; de San José, M.A.; Pieren, A.P.; Peláez, J.R.; Perejón, A. \& Herranz, P. (1987). Episodios sedimentarios en el Alcudiense Superior (Proterozoico) y su tránsito al Cámbrico en la zona centro meridional del Macizo Ibérico. Geogaceta, 2: 43-45.

Yang, B.; Steiner, M.; Zhu, M.; Li, G.; Liu, J. \& Liu, P. (2016). Transitional Ediacaran-Cambrian small skeletal fossil assemblages from South China and Kazakhstan: implications for chronostratigraphy and metazoan evolution. Precambrian Research, 285: 202-215. https://doi.org/10.1016/j. precamres.2016.09.016

Zamarreño, I.; Vegas, R. \& Moreno, F. (1976). El nivel carbonatado de Los Navalucillos y su posición en la sección cámbrica de los Montes de Toledo occidentales (centro de España). Breviora Geologica Asturica, 20: 56-64.

Zhu, M.; Zhuravlev, A.Yu.; Wood, R.A.; Zhao, F. \& Sukhov, S.S. (2017). A deep root for the Cambrian explosion. Implications of new bio and chemostratigraphy from the Siberian Platform. Geology, 45: 459-562. https://doi.org/10.1130/ G38865.1

Zhuravlev, A.; Liñán, E.; Gámez Vintaned, J.A.; Debrenne, F. \& Fedorov, A.B. (2012). New finds of skeletal fossils in the terminal Neoproterozoic of the Siberian Platform and Spain. Acta Palaeontologica Polonica, 57: 205-224. https://doi.org/10.4202/app.2010.0074 